\title{
EFEITO DE CARGAS CÍCLICAS NA RESISTÊNCIA À FRATURA DE DENTES TRATADOS ENDODONTICAMENTE RECONSTRUÍDOS COM PINOS PRÉ-FABRICADOS ESTÉTICOS E METÁLICOS RESTAURADOS COM COROAS DE PORCELANA PURA
}

\section{Anuar Antônio Xible}

Tese de Doutorado apresentada à Faculdade de Odontologia de Bauru, da Universidade de São Paulo, como parte dos requisitos para obtenção do título de Doutor em Reabilitação Oral. 


\title{
EFEITO DE CARGAS CÍCLICAS NA RESISTÊNCIA À FRATURA DE DENTES TRATADOS ENDODONTICAMENTE RECONSTRUÍDOS COM PINOS PRÉ-FABRICADOS ESTÉTICOS E METÁLICOS RESTAURADOS COM COROAS DE PORCELANA PURA
}

\section{Anuar Antônio Xible}

\author{
Tese de Doutorado apresentada à \\ Faculdade de Odontologia de Bauru, \\ da Universidade de São Paulo, como \\ parte dos requisitos para obtenção do \\ título de Doutor em Reabilitação Oral. \\ Orientador: Prof. Dr. Carlos dos Reis \\ Pereira de Araujo
}

Edição Revisada

Bauru

2004 


\begin{tabular}{|l|}
\hline X4e Xible, Anuar Antônio \\
Efeito de cargas cíclicas na resistência à fratura de dentes \\
tratados endodonticamente reconstruídos com pinos pré-fabricados \\
estéticos e metálicos restaurados com coroas de porcelana pura / \\
Anuar Antônio Xible. -- Bauru, 2004. \\
121 p. : il. ; $30 \mathrm{~cm}$ \\
Tese (Doutorado) -- Faculdade de Odontologia de Bauru. USP \\
Orientador: Prof. Dr. Carlos dos Reis Pereira de Araujo
\end{tabular}

Autorizo, exclusivamente para fins acadêmicos e científicos, a reprodução total ou parcial desta tese, por processos fotocopiadores e/ou meios eletrônicos.

Assinatura do autor (a):

Data:

Este projeto de pesquisa $\mathrm{n}^{0}$ 116/2002 foi aprovado pelo Comitê de Ética em Pesquisa da Faculdade de Odontologia de Bauru - USP, em reunião de 23 de Junho 2004, como apresentado no Apêndice. 


\begin{tabular}{|c|c|}
\hline $\begin{array}{l}28 \text { de Junho de } 1967 \\
\text { Santa Tereza - ES }\end{array}$ & Nascimento \\
\hline $1984-1988$ & $\begin{array}{l}\text { Curso de Odontologia na Faculdade de Odontologia } \\
\text { da Universidade Federal do Espírito Santo - ES }\end{array}$ \\
\hline $1993-1996$ & $\begin{array}{l}\text { Aperfeiçoamento em Disfunção Temporomandibular } \\
\text { na Faculdade de Odontologia da Universidade } \\
\text { Federal do Espírito Santo - ES }\end{array}$ \\
\hline $1996-1997$ & Aperfeiçoamento em Prótese Fixa na ABO-ES \\
\hline $1997-2000$ & $\begin{array}{l}\text { Curso de Mestrado em Reabilitação Oral } \\
\text { pela Faculdade de Odontologia de Bauru - USP }\end{array}$ \\
\hline $2002-2003$ & $\begin{array}{l}\text { Doutorado Sanduíche na Goldman School of } \\
\text { Dental Medicine na Boston University - EUA }\end{array}$ \\
\hline Associações & $\begin{array}{l}\text { ABO - Associação Brasileira de Odontologia - ES } \\
\text { SBPqO - Sociedade Brasileira de Pesquisa } \\
\text { Odontológica. }\end{array}$ \\
\hline
\end{tabular}




\section{Dedico este trabalho,}

Ao meu pai, Luíz (in memorian), a quem agradeço o estimulo para estudar, e a todos conhecimentos de vida. O caráter e personalidade são formados a partir dos ensinamentos e convivência com a família.

À minha mãe, Zelinda, a ligação mais pura $e$ despretensiosa de amor e dedicação. Sempre pronta para ouvir e suportar todos as minhas frustrações, e principalmente com uma palavra amiga e de sabedoria para resolvê-las.

Às minhas irmãs, Luzia, Maria Izabel e Silvana, e aos irmãos, José, Jorge, Sérgio e Luiz, que sempre me incentivaram a seguir em frente, dando ajuda incondicional, apoio e incentivo. Isso sempre me fez lembrar o significado de família.

À Jamila e Luis, pelo apoio, carinho e oportunidade de convivência durante minha estada em Boston. 


\title{
Agradecimentos
}

\author{
À Faculdade de Odontologia de Bauru, Universidade de São Paulo, \\ representada na pessoa da Prof ${ }^{a}$. Dra. Maria Fidella de Lima \\ Navarro, Diretora desta Faculdade.
}

Ao Departamento de Prótese da Faculdade de Odontologia de Bauru, representado na pessoa do Prof. Dr. Milton Carlos Gonçalves Salvador, Chefe do Departamento.

Aos Professores Doutores do Departamento de Prótese: Accácio Lins do Valle, Carlos dos Reis Pereira de Araujo, Gerson Bonfante, José Henrique Rubo, José Valdes Conti(in memorian), Luiz Fernando Pegoraro, Lucimar Falavinha Vieira, Milton Carlos Gonçalves Salvador, Paulo César Rodrigues Conti, Paulo Martins Ferreira, Renato de Freitas, Vinícius Carvalho Porto e Wellington Cardoso Bonachela.

\footnotetext{
Ao Prof. Dr. Luis Fernando Pegoraro, pelo apoio e confiança durante todo o curso de doutorado, demonstrados com o comprometimento em minhas atividades como doutorando.
} 


\begin{abstract}
Ao Prof. Dr. José Roberto Pereira Lauris, do Departamento de Odontologia Social da FOB-USP, pelo auxílio na análise estatística deste trabalho.
\end{abstract}

Às secretárias do Departamento de Prótese: Edna, Cláudia, Déborah, pelo pronto atendimento, paciência, carinho e atenção nas situações normais e principalmente nas situações de urgência.

Aos funcionários e ex-funcionários do Departamento de Prótese: Geraldo, Marcelo, Reivanildo, seu Didi e Valquíria.

Aos funcionários da Pós Graduação: Ana Maria, Aurélio, Cleusa, Giane, Letícia.

\begin{abstract}
Aos meus amigos do Doutorado: Carlos, Rudys, Stefania e Vinícius.
\end{abstract}

A todos os colegas da pós-graduação, em especial Lula, Renato, Jéfferson, Rafael, Tatianny, Leylha e Paulo.

À CAPES (Conselho de Aperfeiçoamento de Ensino Superior) pela concessão da Bolsa para realização deste trabalho (Processo 01/01967-5 ) e intercâmbio na Universidade de Boston. 
To my supervisor at Goldman School of Dental Medicine at Boston University:

Dr. Dan Nathanson, for his guidance, support and contribution to this work.

\section{Ao meu orientador:}

Prof. Dr. Carlos dos Reis Pereira de Araujo, pela amizade e confiança na minha capacidade de realização, transmitida pela liberdade de atuação e pronta disposição em me apoiar sempre que necessário.

No processo de formação de doutor, a iniciativa e auto-crítica devem ser constantemente incentivadas. $O$ sucesso de seu aprendizado é a garantia da perpetuação do trabalho, objetivo final do curso.

A todos que de alguma maneira contribuíram para a minha formação como professor, pesquisador, e principalmente como pessoa, direcionando minha vida. 


\section{SUMÁRIO}

LISTA DE FIGURAS....................................................................... vii

LISTA DE TABELAS ....................................................................... viii

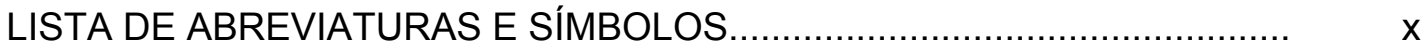

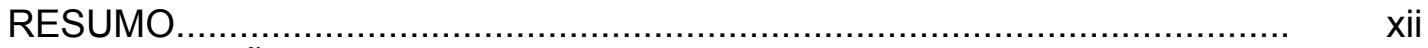

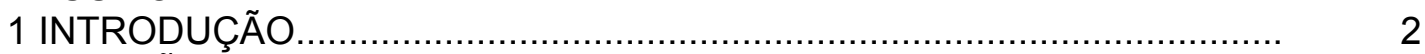

2 REVISÃO DE LITERATURA......................................................... 7

2.1. Materiais dos núcleos intra-radiculares.......................................... 7

2. 2. Características dos pinos pré-fabricados................................ 10

2.3. Tipos de dentes....................................................................... 11

2.4. Preparo dos espécimes.............................................................. 12

2.5. Teste mecânico - ensaio de fadiga ............................................. 14

2.6. Estudos clínicos..................................................................... 17

2.7. Estudos in vitro......................................................................... 24

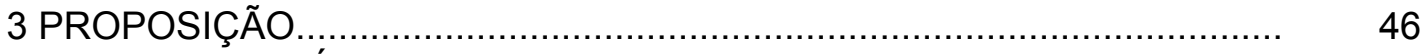

4 MATERIAL E MÉTODOS ............................................................. 48

4.1. Seleção da amostra............................................................... 48

4.2. Preparo dos canais radiculares.................................................. 49

4.3. Constituição dos grupos........................................................ 50

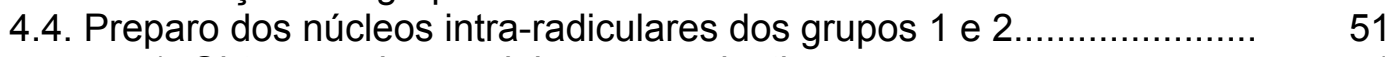

4.4.1. Obtenção dos modelos e ceroplastia....................................... 51

4.4.2. Inclusão e termo-injeção da porcelana vítrea................................. 52

4.4.3. Desinclusão dos núcleos intra-radiculares cerâmicos e ajuste 52 nos modelos.

4.5. Cimentação dos núcleos intra-radiculares cerâmicos e pinos intra- 53

radiculares de resina composta reforçados com fibra de vidro e

e titânio.

4.6. Confecção dos núcleos de preenchimento em resina composta...........

4.7. Repreparo e moldagem dos dentes..............................................

4.8. Confecção das coroas de porcelana pura..................................... 55

4.9. Cimentação das coroas................................................................. 56

4.10. Teste de termociclagem..................................................... 57

4.11. Teste de carga cíclica............................................................... 57

4.12. Teste com carga estática.................................................... 58

4.13. Análise do modo de fratura.......................................................... 59

5 RESULTADOS

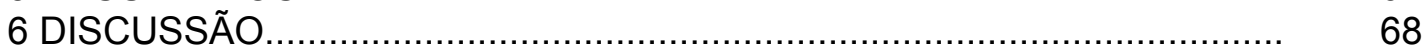

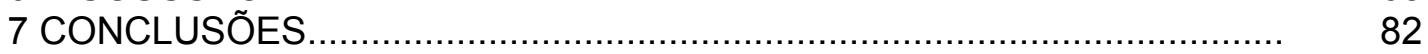

ANEXOS

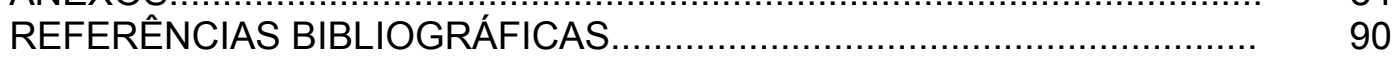

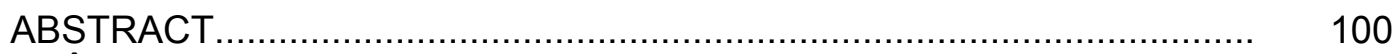

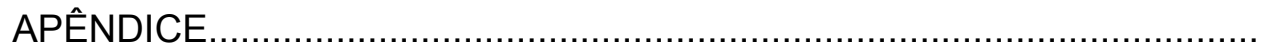




\section{LISTA DE FIGURAS}

FIGURA 4.1: Sistemas de pinos e respectivas brocas utilizados: (A)

51

Zircônia, (B) Resina composta reforçada por fibras de vidro

e (C) Titânio

FIGURA 4.2: Pinos de zircônia após a termo-injeção da porcelana vítrea

52

FIGURA 4.3: Preparo concluído: vistas incisal e lateral 55

FIGURA 4.4: Espécime montado na base metálica para o ensaio de 57 fadiga

FIGURA 4.5: Espécime montado na base de alumínio (a) e durante o teste de carga cíclica (b)

FIGURA 4.6: Espécime posicionado para o teste com carga estática na máquina de testes universal

FIGURA 5.1: Comparação de médias de resistência à fratura $(N)$ entre os grupos-experimentais e controles

FIGURA 5.2: Modo de fratura Supra-crestal no grupo 2

FIGURA 5.3: Modo de fratura Supra-crestal no grupo 4

FIGURA 5.4: Modo de fratura Infra-crestal no grupo 5

FIGURA 5.5: Modo de fratura Infra-crestal no grupo 6 


\section{LISTA DE TABELAS}

TABELA 4.1: $\quad$ Distribuição dos dentes ( $\mathrm{n}^{\circ}$ ) e suas dimensões $(\mathrm{mm}) \mathrm{MD}$

e VL

TABELA 4.2: $\quad$ Estatística descritiva dos valores das dimensões MD dos espécimes

TABELA 4.3: Estatística descritiva dos valores das dimensões VL dos espécimes

TABELA 4.4: Teste de Levene para confirmar igualdade de variância entre os grupos $(p<0,05)$

TABELA 4.5: Teste de ANOVA a 1 critério para verificar a igualdade das dimensões MD dos espécimes $(p<0,05)$

TABELA 4.6: Teste de ANOVA a 1 critério para verificar igualdade das dimensões $V L$ dos espécimes $(p<0,05)$

TABELA 4.7: Constituição dos grupos de acordo com os sistemas de núcleos intra-radiculares, materiais e tratamentos usados

TABELA 4.8: $\quad$ Programa do forno Vulcan 3-550 para evaporação da 86 cera

TABELA 4.9: Programa $\mathrm{n}$ ㅇ 13 do forno EP 500 Ivoclar para termoinjeção de porcelana.

TABELA 4.10: Programa $\mathrm{n}$ ㅇ 11 do forno EP 500 Ivoclar para termoinjeção de porcelana IPS Empress 2

TABELA 4.11: Programação do forno de porcelana Vita Vacumat 40 para aplicação da massa de glaze nas coroas de porcelana IPS Empress 2 pela técnica de maquiagem

TABELA 5.1: Valores individuais de carga, média e desvio-padrão, necessários para fratura dos espécimes, expressos em $\mathrm{N}$

TABELA 5.2: Estatística descritiva para valores de resistência à fratura à carga estática, expressos em $\mathrm{N}$

TABELA 5.3- $\quad$ Teste de Levene para testar a homogeneidade de 88 variância entre as médias dos grupos $(p<0,05)$ 
TABELA 5.4: Teste de ANOVA a 2 critérios, para comparação de carga à fratura, tipos de pinos e carga cíclica $(p<0,05)$

TABELA 5.5: Teste de Tukey para detectar diferenças nos valores de resistência à fratura entre os grupos quanto ao tipo de pinos e influência da carga cíclica $(p<0,05)$

TABELA 5.6: Teste de Correlação de Pearson para análise de correlação entre as dimensões VL e MD dos espécimes e a carga necessária para suas fraturas

TABELA 5.7: Modo de fratura dos espécimes submetidos à carga estática

TABELA 5.8: Teste $Q$ Quadrado $\left(\chi^{2}\right)$ para verificar associação entre os tipos de pinos e modo de fratura, independente da aplicação da carga cíclica

TABELA 5.9: Teste Exato de Fischer para verificar associação entre os tipos de pinos e modo de fratura, nos grupos 1, 3 e 5, não submetidos à carga cíclica

TABELA 5.10: Teste Exato de Fischer para verificar associação entre os tipos de pinos e modo de fratura, nos grupos 2, 4 e 6 , submetidos à carga cíclica 


\section{LISTA DE ABREVIATURAS E SÍMBOLOS}

${ }^{\circ} \mathrm{C}$ - Graus Celsius

$\mathrm{Hz}$ - Hertz

kg - Kilograma

g - Grama

$\mathrm{ml}$ - Mililitro

MPa - Megapascal

GPa - GigaPascal

Mol/\% - Moles por cento

$\mu \mathrm{m}$ - Micrometro

mm - Milímetro

$\mathrm{N}$ - Newton

$\mathrm{CrCb}$ - Liga de Cromo-Cobalto

h - Hora

min - Minuto

rpm - Rotações por minuto

$\Sigma$ - Módulo de Elasticidade de Young

MD - Mésio-distal

VL - Vestíbulo-lingual

$\%$ - Porcento

$\mathrm{n}$ ำ - Número

PPF - Prótese Parcial Fixa

PPR - Prótese Parcial Removível

$X$ - Número de vezes

$\mu$ - Média

ח - Desvio-padrão

4TiVa6Al - Liga de Titânio/Vanádio/Alumínio

$s$ - Segundo

Bar -

cm - Centímetro 
RESUMO 


\section{RESUMO}

Foram avaliados, in vitro, o efeito da aplicação de carga cíclica na resistência à fratura, a resistência à fratura, modo de fratura e associação entre as dimensões $M D$ e VL com resistência à fratura de dentes reconstruídos com sistemas de pinos pré-fabricados metálicos convencionais e estéticos, restaurados com coroas de porcelana pura, submetidos à fadiga térmica e mecânica através de teste à compressão com carga estática. Sessenta caninos íntegros tiveram suas coroas amputadas $1,5 \mathrm{~mm}$ acima da junção cementoesmalte e preparados para coroa de porcelana pura. Os dente foram distribuídos em 6 grupos de 10 dentes. Os grupos 1 e 2 foram restaurados com pinos pré-fabricados de cerâmica de zircônia Cosmopost (Ivoclar-Vivadent) e núcleo de preenchimento em cerâmica vítrea termo-injetada IPS Empress Cosmo Post (Ivoclar-Vivadent). Os grupos 3 e 4 foram restaurados com pinos pré-fabricados de resina composta reforçada por fibra de vidro FibreKor (Jeneric Pentron) e os grupos 5 e 6 com pinos de titânio AZthec Anchor Titanium (Dentatus). Nos grupos 3, 4, 5 e 6 foi usada resina composta reforçada com fibra de vidro Build It FR Fiber Reinforced Core (Jeneric Pentron) como material para núcleo de preenchimento; os dentes foram restaurados com coroas totais IPS Empress 2 (Ivoclar-Vivadent); tanto os pinos quanto as coroas de porcelana foram cimentados com o sistema resinoso de polimerização dupla Cement It / Bond It Primer A + B (Jeneric Pentron). Os espécimes foram submetidos à ciclagem térmica por 300X, em temperaturas de $5^{\circ} \mathrm{C}$ e $55^{\circ} \mathrm{C}$ e incluídos em resina acrílica em blocos de alumínio. Os grupos 2 , 4 e 6 foram submetidos à uma carga cíclica de $250 \mathrm{~N}$ por $500,000 \mathrm{X}$, a uma freqüência de $1,7 \mathrm{~Hz}$. Os 6 grupos foram submetidos à carga estática em uma máquina de testes universal até falha dos sistemas. Após a carga estática os espécimes foram avaliados quanto ao modo de fratura e classificados em 02 tipos: Supra-crestal (SC) - quando a fratura se localizou até $1 \mathrm{~mm}$ abaixo da linha de inclusão dos espécimes na resina acrílica ou Infra-crestal (IC) - quando a linha de fratura se localizou $1,1 \mathrm{~mm}$ ou mais, abaixo da linha de inclusão dos espécimes na resina acrílica. Os dados foram analisados estatisticamente com os testes ANOVA a 2 critérios, Tukey, Correlação de Pearson, Q Quadrado $\left(\chi^{2}\right)$ e Exato de Fischer. $\mathrm{Na}$ análise da resistência à fratura, o valor do grupo 1 
$(1165,5 \pm 211,95 \mathrm{~N})$ foi maior do que o grupo $2(886,50 \pm 170,62 \mathrm{~N})$; o do grupo 3 $(1041,50 \pm 231,20 \mathrm{~N})$ foi maior do que o do grupo $4(762,20 \pm 113,63 \mathrm{~N})$ e o do grupo $5(768,90 \pm 72,95 \mathrm{~N})$ foi maior do que o do grupo $6(985,40 \pm 99,89 \mathrm{~N})$ $(p<0.05)$. O valor do grupo de pinos de zircônia foi significantemente maior do que os grupos de pinos de resina composta reforçados por fibras de vidro e titânio $(p<0.05)$, que foram iguais entre si $(p=0,146)$ independente da aplicação da carga cíclica $(p<0,05)$. A carga cíclica diminuiu significantemente a resistência dos dentes restaurados $(p<0,05)$. Houve fraca, porém significante relação entre a dimensão MD e resistência à fratura dos espécimes $(r=0,260 \mathrm{e}$ $\mathrm{p}=0,044)$. Na análise do modo de fratura, o grupo 1 apresentou $30 \%$ de fraturas SC e $70 \%$ IC; o grupo 2 apresentou $60 \%$ de fraturas SC e $40 \%$ IC; o grupo 03 apresentou $60 \%$ de fraturas SC e $40 \%$ IC; no grupo 4 houve $90 \%$ de fraturas SC e $10 \%$ de IC; no grupo 5 houve $40 \%$ de fraturas SC e $60 \%$ de IC enquanto no grupo $6,50 \%$ de fraturas SC e $50 \%$ IC. Não houve correlação entre o tipo de pino e modo de fratura $\left(\chi^{2}=0,484\right.$ e $\left.p=0,885\right)$, independente do uso de carga cíclica. Em conclusão, os dentes restaurados com pinos de zircônia e núcleos de preenchimento de porcelana vítrea apresentaram os melhores valores de resistência à fratura, independente da aplicação de carga cíclica, entre os grupos testados; o tratamento com carga cíclica reduziu significantemente a resistência em todos os grupos testados. Não houve diferença de resistência à fratura entre os grupos restaurados com resina composta reforçado por fibra de vidro e titânio, independente da aplicação da carga cíclica. Não houve correlação entre o tipo de pino e o modo de fratura, e, quanto maior a dimensão MD dos espécimes, maior a força necessária para levá-los à fratura. 
INTRODUCÃO 


\section{INTRODUÇÃO}

Os dentes tratados endodonticamente são mais predispostos a falhas

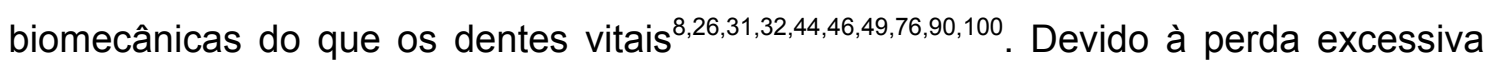
de substância coronária, uma estabilização corono-radicular é geralmente requerida, especialmente em dentes anteriores, para fornecer forma de retenção e resistência para a restauração final ${ }^{1,4,5,8,15,26,29,31,32,44,49,50,51,52,59,62,64,66,69,74,76,90}$. Nestes casos, a confecção de núcleos intra-radiculares é o melhor procedimento a ser indicado. No entanto, em oposição à retenção adquirida para a coroa, esta técnica pode gerar um risco aumentado de fratura à estrutura dental danificada ${ }^{1,5,6,26,29,31,32,44,46,53,62,76,98,99,102}$.

Núcleos intra-radiculares ideais devem impor um estresse mínimo aos remanescentes dentais, devendo os pinos intra-radiculares fornecer retenção e estabilidade adequadas aos núcleos de preenchimento, e permitir fácil remoção do canal radicular, se necessário. Além disso, os núcleos intra-radiculares devem transferir forças oclusais de maneira estratégica ao remanescente dental, para não levar à fratura deste $1,4,6,24,28,31,32,53,73,76,88,90,97,98,106$.

A quantidade de estrutura dental remanescente, por sua vez, dita o tipo de núcleo intra-radicular que deve ser usado. Se ocorre uma perda de tecido dental, onde após o preparo para a restauração final, um remanescente maior do que $1,5 \mathrm{~mm}$ permanece intacto na porção coronária, pode-se optar por núcleos intra-radiculares confeccionados a partir de pinos pré-fabricados e núcleos de preenchimento $9,31,32,41,55,76,97,99$. No entanto, se a perda horizontal é acentuada, e o efeito de férula de $1,5 \mathrm{~mm}$ não pode ser criado, existem poucas alternativas para reconstrução deste, levando ao inexorável uso dos núcleos intra-radiculares metálicos fundidos $^{31,32,41,66,74,76,97}$. Estes têm sido referidos como o padrão dourado dentre os núcleos intra-radiculares, decorrente de suas taxas de sucesso clínico, que podem chegar a $98 \%$ após 10 anos $^{26,30,44,74,102}$. Este alto índice de sucesso, aliado às técnicas de confecção de coroas de porcelana com infra-estrutura opaca, garante tranquilidade ao cirurgião-dentista quando opta por este planejamento de tratamento de dentes tratados endodonticamente.

Com o advento da técnica de confecção de núcleos intra-radiculares com pinos pré-fabricados metálicos e núcleos de preenchimento em resina composta $^{8,31,32,76}$, muitos esforços têm sido feitos para comparar o desempenho dessa 
técnica com a dos núcleos metálicos fundidos. A análise de estudos, tanto clínicos como laboratoriais, envolvendo estes sistemas, revela estreita semelhança nos resultados dos critérios avaliados $2,26,27,30,31,32,50,52,55,74,76,83,84,90,92,97,102,106$.

As modernas tendências em odontologia restauradora com o advento da técnica adesiva de maneira geral $^{2,7,13,17,18,22,23,28,33,34,36,38,40,43,47,48,51,54,61,63,70,71,75,80,81,82,85,103,104}$, junto com uma difusão de crescimento das técnicas de confecção de coroas totais sem metal, permitem que os núcleos intra-radiculares não interfiram no resultado estético do tratamento reabilitador ${ }^{1,11,12,25,45,57,59,62,64,90,95,96,101}$. Quando uma coroa de porcelana pura translúcida é cimentada ao dente com tratamento endodôntico com um cimento translúcido, a coloração escura da raiz, se presente, pode se tornar visível através da porção cervical da coroa 1,18,59,64,77,96,101. Esse fenômeno pode ser mais pronunciado quando núcleos intra-radiculares metálicos são usados, podendo enfatizar a descoloração acinzentada nas coroas de porcelana pura translúcidas e gengiva circundante. Esses problemas, assim como a crescente demanda por restauracões estéticas, têm levado ao desenvolvimento de sistemas de núcleos intra-radiculares sem metal 1,6,21,25,39,42,59,62,68,69,71,85,90,95,101,103. Dos vários sistemas disponíveis, os mais comuns e de menor custo são os pinos de resina composta reforçados por fibras de vidro ou quartzo, conjugados com núcleos de preenchimento em resina composta, seguidos dos pinos de cerâmica de zircônia conjugados com porcelana vítrea, termoinjetada sobre estes, ou associados à resina composta. Esses materiais têm importantes vantagens estéticas sobre ligas metálicas, além de evitar a corrosão galvânica, e redução de toxicidade advinda da difusão de íons metálicos ${ }^{16,21,39,42,86,90,95}$.

Os pinos de resina composta reforçados por fibras estéticas têm como uma das principais características o módulo de elasticidade semelhante ao da dentina, o que aliado a técnica de cimentação resinosa intra-canal permite que o material restaurador acompanhe a elasticidade da dentina remanescente, quando esta é submetida a cargas ${ }^{28,31,32,36,42,56,61,65,71,73,84,89,90,91,92,97}$. O baixo módulo de elasticidade e dureza permitem fácil remoção destes pinos dos canais quando necessário, além de alta resistência flexural, o que o indica como material adequado para a confecção de pinos intra-radiculares ${ }^{19}$. Estes pinos são compostos de fibras de vidro unidirecionais embebidos em matriz resinosa que reforçam a estrutura do pino sem comprometer o módulo de elasticidade ${ }^{42,65}$.

Os pinos de cerâmica foram propostos pela primeira vez em 1967, utilizando cerâmica à base de alumina ${ }^{90}$; em 1989, KWIATKOWISKY e GELLER ${ }^{64}$ 
descreveram núcleos intra-radiculares em cerâmica feldspática. Mais recentemente foram introduzidos os pinos de cerâmica à base de dióxido de zircônio ou zircônia ${ }^{25,59,67,90,95,101}$. Apesar de favorecerem a estética na reconstrução de dentes tratados endodonticamente, este material tem alto módulo de elasticidade, em torno de 200GPa, assim como a resistência flexural, características estas similares as do aço não inoxidável ${ }^{6,21,86,90}$. Estas propriedades limitam a fabricação de núcleos intraradiculares em monobloco com este material, mas podem ser consideradas vantajosas, desde que, reduzem o risco de fratura das coroas cerâmicas. Ao mesmo tempo, aumentam o risco de fratura do próprio pino ou da raiz. Quando a fratura ocorre nesta última, ela pode ser de caráter irrecuperável, o que torna este material inaceitável para uso clínico $28,31,32,71,84,90$.

$\mathrm{Na}$ procura de novos materiais, que forneçam características estéticas superiores às fornecidas pelo sistema de coroas com infra-estrutura opaca e núcleos metálicos fundidos, deve-se considerar que além destas, é de primordial importância que a expectativa de sucesso clínico de todo o complexo restaurador seja comparável a das técnicas convencionais. Neste aspecto, existem informações limitadas na literatura relatando comparações de sistemas de núcleos intra-radiculares confeccionados com materiais de diferentes módulos de elasticidade tais como zircônia, resina composta ou titânio, e seus efeitos na resistência de dentes tratados endodonticamente. As comparações mais comuns são as feitas em trabalhos laboratoriais, onde estes materiais são, geralmente, comparados com materiais de reconhecido sucesso clínico, tais como os núcleos intra-radiculares metálicos $^{2,15,28,40,50,51,56,71,73,74,79,84,89,91,92,93,94}$. Dentre os recursos disponíveis em laboratório, os testes de carga cíclica utilizando máquinas de fadiga, é um que tem fornecido dados valiosos na previsão do desempenho clínico destes materiais, além de ser um importante passo para direcionar os experimentos clínicos ${ }^{107}$. Estes testes têm sido estabelecidos como sendo um instrumento de pesquisa essencial para testar restaurações adesivas, porque eles reproduzem padrões de carga cíclica comparáveis à função fisiológica presentes na cavidade oral, e portanto, podem simular os resultados de experimentos clínicos, os quais demandam muito tempo para execução. Estudos mais recentes também têm usado tais recursos para testar sistemas de núcleos intra-radiculares ${ }^{15,22,28,37,40,50,51,52,55,56,66,71,83,89,92,94}$.

Os resultados dos estudos de laboratório, onde os espécimes foram reconstruídos com pinos pré-fabricados estéticos e metálicos, restaurados com coroas totais, revelam resultados não conclusivos ${ }^{15,50,51,52,89,92,94}$. O desempenho daqueles 
restaurados com pinos pré-fabricados de zircônia geralmente mostram resistência à fratura maior do que os pinos de resina composta reforçados por fibras, sendo ambos superiores aos restaurados com pinos metálicos. Por outro lado, contrariamente aos outros dois sistemas, o uso de pinos de resina composta reforçados por fibra parece induzir um tipo de fratura mais favorável, de caráter recuperável, ou seja, permite que uma nova restauração seja confeccionada, reaproveitando o remanescente dental. $O$ uso de carga cíclica parece não afetar a ordem de resistência dos espécimes, embora os trabalhos comparando o efeito da carga cíclica sobre os diversos sistemas de núcleos intra-radiculares sejam muito escassos.

Clinicamente, dos muitos fatores envolvidos nas falhas dos núcleos intra-radiculares, alguns estão relacionados às propriedades mecânicas dos pinos $^{26,30,31,32,53,56,58,65,71,72,74,79,90,92,94}$. Obviamente, esse é o caso da distorção e fratura dos pinos intra-radiculares, onde um alto módulo de elasticidade e resistência reduziriam essas possibilidades. Perda de retenção de uma coroa, por sua vez, é indubitavelmente relacionada à qualidade do seu suporte, que novamente reflete módulo de elasticidade do pino intra-radicular.

A respeito de fratura radicular, existe um consenso de que aumentar o diâmetro do pino intra-radicular fa-lo-á mais resistente, mas menos estrutura dental remanescerá, e um efeito combinado pode ser uma redução da resistência do conjunto. A situação é menos óbvia quando a rigidez do pino é considerada. Reduzir o estresse na dentina radicular ao mínimo possível faz alguns autores suportarem a idéia de que um pino intra-radicular de alta rigidez leva a uma distribuição mais igual do estresse ao longo da raiz, enquanto outros suportam que pinos intra-radiculares de baixo módulo de elasticidade e menor rigidez cumprem este requisito de forma mais adequada $1,2,5,15,28,29,31,36,50,51,52,56,62,64,65,71,72,73,74,90,91,92,94,95,101,103$.

Assim, foi proposto analisar a influência de três sistemas de reconstrução de núcleos intra-radiculares obtidos a partir de três materiais com diferentes propriedades mecânicas, na resistência à fratura, modo de fratura e ainda, o efeito da carga cíclica na resistência à fratura e possível associação entre as dimensões $M D$ e $V L$ e resistência à fratura, de dentes tratados endodonticamente reconstruídos com aqueles sistemas. 
REVISÃO DA LITERATURA 


\section{REVISÃO DE LITERATURA}

\subsection{Materiais dos núcleos intra-radiculares}

Estudos que têm comparado as propriedades mecânicas de diferentes sistemas de pinos pré-fabricados/núcleos de preenchimento sugerem que a habilidade de resistir às forças mastigatórias e proteger a raiz de falhas biomecânicas de cada sistema pode variar enormemente 5,8,9,24,27,28,36,37,40,46,50,55.56.68,71,73,74,76,84,86,90,91,97,102,106. . Atualmente, o principal questionamento é se um sistema de pinos pré-fabricados com propriedades mecânicas de valores mais altos tais como rigidez e resistência flexural maiores seria mais desejável para tal fim $6,8,9,15,51,52,53,71,73$.

Os pinos pré-fabricados metálicos têm sido preconizados em associação com núcleos de preenchimento feitos de resina composta desde a década de 70, como base para retenção de coroas totais ${ }^{2,5,15,22,28,29,31,32,40,44,55,76,92,94,97,102}$. Estudos clínicos de longo prazo têm evidenciado a eficácia e confiabilidade desta técnica, que tem como principal vantagem a sua confecção em uma sessão única, em detrimento às técnicas de núcleos metálicos fundidos que exigem duas sessões clínicas para sua confecção ${ }^{4,8,15,29,30,31,32,46,73,76,89,92,94,102}$. Essas vantagens, no entanto, são sobrepostas por algumas limitações estéticas para o uso desse material como base retentora quando se usam coroas de porcelana pura translúcida em dentes anteriores.

Dentre os tipos de ligas metálicas, para confecção de pinos préfabricados disponíveis, que preenchem requisitos tais como resistência mecânica, resistência à corrosão e baixo custo, as ligas de 4TiVa6Al são as mais adequadas $^{31,32,35,86,90}$. Essas ligas se mostram inertes em meio tecidual, apresentam baixo nível de corrosão ou oxidação e altos valores de resistência estrutural, permitindo confecção de pinos intra-radiculares de proporções reduzidas, ideais para restaurações intra-radiculares.

No contexto do desenvolvimento de materiais e técnicas, o advento da cimentação resinosa associado às técnicas de condicionamento ácido do substrato dentário e aplicação de adesivos permitiu tanto a cimentação de peças protéticas, principalmente coroas e facetas de porcelana vítrea, como a posterior extensão do seu 
uso para a cimentação de pinos pré-fabricados intracanal $^{3,7,11,12,13,17,18,31,32,57,59,63,64,65,70,72,73,76,78,80,81,82,85,87,90,93,96,101,103,104}$.

Recentemente, foram desenvolvidos pinos pré-fabricados de resina reforçados por fibras os quais, por requisito de resistência, exigem cimentação resinosa 3 ,13,18,28,31,32,34,40,79,80,85,103,104. Inicialmente, foram desenvolvidos pinos de resina epóxica reforçados por fibras de carbono, com boas propriedades mecânicas e relatos de desempenho clínico em curto prazo promissores ${ }^{36,72,90}$. No entanto, a cor escura das fibras de carbono presentes restringia o seu uso em regiões consideradas estéticas e foram substituídos por materiais estéticos tais como fibras de quartzo e cerâmica. Mais recentemente foram desenvolvidos os pinos de resina composta reforçados por fibra de vidro, que têm exibido propriedades estéticas melhoradas, propriedades mecânicas satisfatórias e facilidade de assegurar uma cimentação resinosa eficiente, pois permitem transmissão de luz halógena em toda a extensão do canal preparado para o pino, e conseqüente superior conversão de monômeros dos adesivos dentinários e cimentos resinosos ${ }^{18,34,43,90,103,104}$. Por suas propriedades mecânicas tais como resistência à fratura, módulo de elasticidade, que é similar ao da dentina, têm-se sugerido que seu uso reduz o risco de fratura do remanescente e, em caso de fratura da raiz, que o remanescente dental que seja passível de recuperação com uma nova restauração ${ }^{19,27,28,31,32,36,71,73,91,92}$.

As cerâmicas à base de dióxido de zircônio ou cerâmica de zircônia são compostas em $96,5 \mathrm{~mol} / \%$ por dióxido de zircônio, que foram inicialmente estabilizadas em uma fase tetragonal, em temperatura ambiente, por óxidos tais como o de cálcio ou o de magnésio. Inicialmente, seu uso na área de saúde se restringiu à área de ortopedia como próteses de epífises ósseas, mas sofriam deterioração devido à umidade do meio e não apresentavam boas propriedades mecânicas de resistência ${ }^{21}$. A substituição desses óxidos por óxido de ítrio em concentrações da ordem de $3,5 \mathrm{~mol} / \%$ melhorou as propriedades da cerâmica, que passou a exibir propriedades mecânicas mais estáveis ${ }^{16,35,45,68,86}$. Sua coloração branca opaca a qualificou como material restaurador em dentes tratados endodonticamente. Inicialmente, foi utilizado para confecção de pinos pré-fabricados em associação com núcleos de preenchimento obtidos em cerâmica vítrea termo-injetada ${ }^{1,69}$. O núcleo de preenchimento era fundido e tratado superficialmente com ácido hidrofluorídrico, silanizado, e em seguida cimentado ao pino pré-fabricado com cimento resinoso. Mais recentemente, com o controle do coeficiente de expansão térmica da cerâmica vítrea em relação à cerâmica de zircônia, esta passou a ser fundida e injetada diretamente 
sobre o pino pela técnica da cera perdida $25,59,95,101,105$. Os altos valores de resistência do conjunto permitem que sejam, inclusive, cimentados intra-canal com cimento de fosfato de zinco e ionômero de vidro, além dos cimentos resinosos. Mas, apesar de permitir fácil confecção e estética, esses materiais ainda deixam dúvidas quanto ao seu comportamento clínico em termos de longo prazo. Características como alto módulo de elasticidade, em torno de $200 \mathrm{GPa}^{16,21,35,68,86}$, fizeram diversos autores contra-indicar o seu uso como pino pré-fabricado intra-radicular, uma vez que induziria a concentração de estresse no remanescente dentário, levando a uma iminente fratura, sobretudo de caráter irrecuperável, para o remanescente dental $\left.\right|^{18,27,28,36,71,72,84,90,92,103}$. No entanto, os pinos pré-fabricados estéticos tanto de resina composta reforçados por fibras como os de cerâmica à base de zircônia ainda carecem de estudos clínicos, em longo prazo, que comprovem a sua eficiência.

As resinas compostas têm sido usadas para confecção de núcleos intraradiculares em associação com pinos pré-fabricados metálicos desde o início da década de $70^{8,31,32,76}$. Diversos trabalhos de laboratório demonstram que suas propriedades mecânicas são superiores em relação aos materiais ionoméricos e similares às do amálgama ${ }^{20,22,23,40}$. Estudos clínicos têm evidenciado que a associação de pinos pré-fabricados metálicos e núcleos de preenchimento em resina, para reconstrução de remanescentes dentais previamente à restauração com coroas totais, têm alta taxa de sucesso clínico, variando de 67,9\% em dentes comprometidos periodontalmente após 9,5 anos, até 94\% para dentição com implantação normal após 9 anos $^{4,26,30,44,52,76,102}$. Além dos pinos pré-fabricados, as resinas compostas para núcleos de preenchimento também tiveram sua composição modificada pela adição de fibras de vidro que Ihes proporcionaram propriedades mecânicas melhoradas em relação às resinas compostas convencionais ${ }^{14,32}$.

O desenvolvimento de cimentos resinosos e adesivos de polimerização dupla aliado ao condicionamento ácido das superfícies dentinárias, que permitem obter valores consideráveis de adesão das resinas compostas aos tecidos dentais, aumentou o espectro de indicações das técnicas que fazem uso dos materiais resinosos ${ }^{13,17,34,38,43,48,63,70,78,85,103,104}$. O uso da cimentação resinosa, por exemplo, passou a ser considerado benéfico nos casos de cimentação de pinos intra-radiculares pois, além das características favoráveis de adesão, gera a formação de uma camada de cimento entre o pino pré-fabricado e o dente, a qual funcionaria como absorvedor de estresse mastigatório, uma vez que o módulo de elasticidade similar ao do dente formaria uma extensão do mesmo. No caso de uso de pino pré-fabricado de resina 
composta reforçado por fibras, a cimentação resinosa traz ainda mais benefícios, pois além de prover maior resistência ao pino, forma um corpo único com o dente, suportando e distribuindo melhor o estresse mastigatório ${ }^{18,22,28,36,54,71,72,73,79,90,91,92}$.

\subsection{Características dos pinos pré-fabricados}

Alguns estudos têm relatado um efeito deletério de cunha atribuído a núcleos intra-radiculares cônicos ${ }^{44,52,66,98}$. Assim como os núcleos metálicos fundidos, que copiam a anatomia intra-canal, geralmente cônica, os pinos pré-fabricados cônicos têm sido responsabilizados pelo efeito de cunha estabelecendo menor resistência à fratura de dentes tratados endodonticamente. Alguns autores relatam que há uma melhor distribuição de estresse ao redor do remanescente dental com o uso de pinos pré-fabricados não cônicos, em relação aos núcleos metálicos fundidos de forma cônica ${ }^{24,55}$, mas outros não conseguiram demonstrar diferenças entre os pinos pré-fabricados paralelos e pinos pré-fabricados cônicos ${ }^{5,24,52}$.

Aliado à forma dos pinos pré-fabricados, o diâmetro também desempenha um papel na resistência dos dentes tratados endodonticamente reconstruídos com núcleos intra-radiculares. Estudos de comparações da resistência de grupos de dentes restaurados com e sem núcleos intra-radiculares, concluíram que os dentes nos quais não são usados núcleos intra-radiculares são mais resistentes à fratura por carga estática ${ }^{31,32,46,51}$, sugerindo que a remoção de tecido dentário necessária para instalação dos pinos pré-fabricados diminui a resistência dos dentes à fratura, ao invés de aumentá-la. Mas a remoção de tecido em quantidades muito similares parece não ter relação direta com a resistência à fratura dos dentes tratados endodonticamente reconstruídos com núcleos intra-radiculares. AKKAYAN; GÜLMEZ ${ }^{2}$ compararam a resistência à fratura de dentes tratados endodonticamente restaurados com pinos de titânio, resina composta reforçado por fibras e pinos de zircônia, cujos diâmetros variaram de 1,5 a 1,7mm. Os maiores valores foram achados para os pinos com menor diâmetro (ParaPost Fiber White ${ }^{\circledR}$ - de $1,50 \mathrm{~mm}$ ), os piores, para pinos de titânio $(1,65 \mathrm{~mm})$, sugerindo não haver correlação entre o diâmetro do pino e resistência à fratura.

As diferentes texturas de superfície, por sua vez, podem ser relacionadas com a adesão de um cimento à superfície do pino pré-fabricado, influenciando na estabilidade do pino quando submetido ao estresse. AL-HARBI e 
NATHANSON ${ }^{3}$ relataram que os pinos pré-fabricados de resina composta reforçados por fibra de vidro apresentaram maior resistência à remoção por força de tração nos remanescentes radiculares do que os de cerâmica de zircônia, mas igual aos dos pinos de titânio com retenções mecânicas. MILLER et $\mathrm{al}^{75}$ testaram a resistência à remoção por força de tração de sistemas de cimentação resinosa a pinos préfabricados metálicos confeccionados com diferentes ligas, com posterior análise microscópica. Houve uma grande variabilidade de interação com bons valores entre diferentes cimentos e metais, fazendo com que os autores recomendassem que a seleção do cimento deve ser baseada no metal e tratamento de superfície usado. A retenção ao canal radicular de pinos pré-fabricados metálicos com diferentes texturas superficiais, depende não somente da superfície de contato, mas também do ângulo de convergência das paredes dos pinos, da espessura da camada de cimento, forma dos pinos, neste caso incluíndo-se a presença de retenções mecânicas e, finalmente, a forma do canal ${ }^{78}$. É consenso, no entanto, que os pinos de paredes paralelas são mais retentivos do que os de paredes puramente cônicas $3,24,31,32,75,76,78$.

Considerando a retenção do núcleo de preenchimento aos pinos préfabricados, aquela oferecida pelos pinos pré-fabricados de cerâmica de zirconia à cerâmica vítrea é igual àquela oferecida pelos pinos de titânio com retenções mecânicas horizontais à resina composta ${ }^{105}$. É relatado, também, que a retenção oferecida aos núcleos de preenchimento de resina composta pelos pinos de titânio foi igual à dos pinos de resina composta reforçados por fibra de vidro, que foram maiores do que os de cerâmica à base de zircônia ${ }^{3}$.

\subsection{Tipos de dentes}

Dentes humanos têm sido comumente usados para testar, in vitro, as reconstruções de núcleos intra-radiculares $2,9,15,27,37,43,50,51,54,55,66,78,79,83,84,85,89,92,94,98,99,100$. A principal desvantagem destes é sua grande variação em tamanho e parâmetros mecânicos ${ }^{61,70}$, geralmente resultando em grandes desvios-padrões dos resultados. Para contornar esses problemas, alguns autores têm usado tanto dentes bovinos ${ }^{55}$ como dentes de acrílico ${ }^{40,91}$. Enquanto os dentes bovinos são comparados aos dentes humanos em módulo de elasticidade, resistência à tração e características de adesão, ao se considerar que a proporção coroa/raiz é um fator preponderante no sucesso de tratamento de dentes tratados endodonticamente, os dentes bovinos sofrem de um inaceitável exagero de tamanho em relação aos dentes humanos. Dentes de resina, 
por outro lado, além de reproduzirem o tamanho dos dentes humanos, podem ser padronizados em um só tamanho e material, mas não simulam apropriadamente as propriedades de adesão e elasticidade inerentes daqueles ${ }^{41,50,51,84}$. Uma das soluções para minimizar os problemas inerentes ao uso de dentes humanos é fazer uma distribuição dos dentes pelo método estratificado ${ }^{2,71}$. Em trabalhos nos quais os dentes são reconstruídos com núcleos intra-radiculares e restaurados com coroas totais, é importante que seja medido o tamanho do remanescente dental após o preparo, e não os dentes íntegros, evitando assim o problema da variação de tamanho das coroas anatômicas ${ }^{2,71}$.

\subsection{Preparo dos espécimes}

Além do material dos núcleos intra-radiculares, a quantidade de remanescente coronário e a qualidade da restauração final sobre este estão entre os fatores que influenciam sobremaneira o prognóstico de dentes tratados endodonticamente.

Embora alguns estudos não relatem o preparo e obturação de canal ${ }^{40,92}$, a inclusão deste passo é essencial para simular cuidadosamente todos os parâmetros clínicos. Os dentes que recebem núcleos intra-radiculares são sempre tratados endodonticamente, resultando em pequena, mas não negligenciável perda de tecido dental. Uma vez que este fator pode influenciar os resultados, o tratamento endodôntico é mandatário para se obter resultados confiáveis ${ }^{46,51}$. Nesse aspecto, a presença de eugenol no cimento de obturação endodôntica, gera dúvidas quanto à sua influência na polimerização do sistema resinoso usado para cimentação do pino pré-fabricado intra-radicular. No entanto, a resistência de adesão de pinos préfabricados cimentados com cimento resinoso a dentes obturados endodonticamente com cimento resinoso é considerada igual àquela conseguida quando se usa tanto cimento à base de hidróxido de cálcio como cimento à base de óxido de zinco e eugenol, desde que o condicionamento ácido adequado seja feito previamente à cimentação ${ }^{47,91}$. Apesar disso, na maioria dos trabalhos revisados, o cimento de obturação de canais usado foi à base de resina ou hidróxido de cálcio ${ }^{2,5,15,18,19,22,24,28,37,50,51,55,56,71,73,89}$.

Embora tenha sido relatado que existe grandes diferenças na taxa de sobrevivência durante o teste de carga cíclica ou resistência à fratura sob carga 
estática entre os dentes tratados endodonticamente, reconstruídos com pinos préfabricados estéticos e coroa de porcelana pura, um dos fatores responsáveis por esta diferença pode ter sido a ausência do efeito de férula ${ }^{28,56,71}$. A este respeito, no preparo do remanescente radicular dental, é preconizada a presença de remanescente coronal de, no mínimo, $1,5 \mathrm{~mm}$ para que sejam usados sistemas restauradores de pinos pré-fabricados/núcleos de preenchimento ${ }^{9,41,52,55,99}$. Não existe dúvida de que uma coroa cria um efeito de férula sobre o núcleo intra-radicular quando suas margens contornam um colar de dentina saudável com essas dimensões ${ }^{2,9,15,52}$.

Alguns autores discutem o não uso de uma restauração final com coroas em espécimes que foram reconstruídos com núcleos intra-radiculares nos trabalhos in vitro ${ }^{9,22,79,93}$. Tal procedimento poderia mascarar o efeito da reconstrução com diferentes técnicas de núcleos intra-radiculares. No entanto, pode ser concluído também que realmente existem poucas diferenças entre a grande quantidade de tipos de pinos pré-fabricados e sistemas de reconstrução quando uma coroa total vai ser confeccionada $^{52}$. Atualmente, é de consenso geral que testar espécimes sem coroas não simularia uma condição clínica, além de uma férula de pelo menos $1,5 \mathrm{~mm}$, o que asseguraria um prognóstico favorável para a restauração com coroa total do dente $^{2,9,31,32,41,50,51,55,76,99}$.

Ainda considerando o recobrimento total, o material da coroa e o tipo de material utilizado para cimentá-las podem influenciar nos resultados do trabalho. Em todos os trabalhos revisados, exceto 3 , os autores utilizaram coroas metálicas e cimentação convencional. Dos 3 trabalhos citados com exceção, onde foi testada a resistência à fratura de dentes anteriores reconstruídos com diferentes sistemas de núcleos intra-radiculares, em dois ${ }^{89,94}$, os dentes foram restaurados com copings de cerâmica de alumina cimentados com o sistema resinoso Panavia $21 \mathrm{TC}^{\circledR} /$ Scotchbond Multipurpose ${ }^{\circledR}$. Nesses trabalhos, os autores relataram alto índice de fratura das coroas, o que pode ter sido causado pelos baixos valores de adesão conseguidos entre cerâmicas à base de alumina e cimentos resinosos ao dente. Esta adesão, aliada à fina espessura dos copings $(0,6 \mathrm{~mm})$, que confere uma resistência mecânica menor que determinados pinos intra-radiculares, certamente influenciou no resultado dos valores de resistência à fratura dos espécimes, uma vez que o coping pode ter-se fraturado antes dos sistemas de núcleos intra-radiculares ou das raízes, ou seja, em realidade, o que pode ter sido testada foi a resistência à fratura das coroas de cerâmica, levando a conclusões distorcidas quanto aos resultados dos trabalhos. No terceiro trabalho, MANNOCCl et al. ${ }^{71}$ utilizaram coroas Empress ${ }^{\circledR}$ para restaurar os 
dentes tratados endodonticamente reconstruídos com núcleos intra-radiculares estéticos. Nesse estudo, foi feito teste de carga cíclica destrutiva e medida a taxa de sobrevivência dos espécimes, sendo que aqueles restaurados com pinos préfabricados de zircônia apresentaram taxa de sobrevivência menor do que os restaurados com pinos pré-fabricados de resina. Os espécimes não tiveram efeito de férula, o que pode ter gerado resultados enganosos.

\subsection{Teste mecânico - ensaio de fadiga}

As falhas de próteses parciais fixas ocorrem devido, entre outros, a fatores biológicos, por exemplo, relacionados à presença de placa, e mecânicos, nas quais fraturas sempre estão presentes em uma proporção significante. As falhas em curto prazo e sobrecarga aguda são muito raras, e geralmente relacionadas aos materiais, presença e forma das trincas ou trauma, enquanto as falhas mecânicas em longo prazo ocorrem depois de 5 a 10 anos. Assim, a maioria das falhas mecânicas é atribuída a um processo que alcança o final catastrófico somente após muitos anos de serviço. Geralmente, o que ocorre é uma fissura crescendo lentamente sob estresse de fadiga, com enfraquecimento estrutural do componente e, finalmente, a fratura. Isso justifica a ênfase que deve ser colocada na caracterização de materiais dentários e estruturas, por testes com uso de carga cíclica ${ }^{107}$.

Em estudos mais simples encontrados na literatura, os dentes são restaurados com diferentes sistemas de núcleos intra-radiculares e submetidos à carga estática até a fratura do sistema, sendo então comparados os valores de resistência à fratura dos grupos ${ }^{2,56,73}$. Enquanto a aplicação de carga estática não necessariamente simula a carga intra-oral, a hipótese geral é que ela poderia, pelo menos, detectar diferenças entre variadas modalidades de tratamento com respeito à resistência dos espécimes testados. Trabalhos de comparação, que simulam condições clínicas com carga cíclica, são mais relevantes clinicamente, mas muito escassos até meados da década de $1990^{52}$.

De maneira geral, inter-relações já conhecidas indicam que cargas cíclicas maiores causarão falha após poucos ciclos, enquanto que o material pode suportar um número infinito de ciclos se a carga é diminuída, ou seja, como regra, geralmente quanto menor o estresse aplicado, maior o número de ciclos de carga suportados por um espécime. Tal comportamento é tradicionalmente projetado em um 
gráfico referido como um diagrama S-N (Carga - $\mathrm{n}^{\circ}$ de ciclos) ou curva de resistência ${ }^{107}$.

WISKOTT; NICHOLLS; BELSER ${ }^{107}$, preconizam que os testes de carga cíclica em trabalhos laboratoriais de Odontologia devem ser programados com pelo menos $10^{6}$ ciclos se é desejado estimar um tempo de serviço de relevância clínica para materiais dentários. Além disso, que os diagramas Carga $/ n^{\circ}$ de ciclos não são requeridos, uma vez que esquemas de baixo número de ciclos (menos do que $10^{6}$ ) são aplicáveis somente para materiais temporários e subestruturas.

Diversos estudos in vitro utilizam a carga cíclica num modelo $\mathrm{S}-\mathrm{N}$, ou seja, submetem os corpos de prova à carga cíclica até haver falha dos espécimes por fadiga, e relatam a taxa de sobrevivência dos espécimes, relacionando assim, o efeito dos diferentes pinos pré-fabricados com a taxa de sobrevivência dos dentes. São os chamados testes de carga cíclica destrutiva ${ }^{22,71}$.

Outros trabalhos têm usado a carga cíclica, inicialmente, com valores que simulam uma carga de valores próximos ao que os dentes anteriores são submetidos na cavidade oral e, posteriormente, submetem os espécimes à carga estática para que a resistência residual dos espécimes seja quantificada. Outros, ainda, submetem os dentes restaurados à carga cíclica e posteriormente analisam, através de microscopia ótica e/ou eletrônica, o grau de infiltração de corante e/ou a degradação da linha de cimento e/ou grau de desadaptação das coroas ${ }^{28,37}$.

O tipo de máquina utilizado no teste é mandatário nos parâmetros e tipo do teste. Muitas máquinas de fadiga contemporâneas têm mecanismo baseado em circuito de loop fechado servo-hidráulico sob pressão, no qual uma ponta impõe uma carga do tipo impacto no espécime, gerando estresses que podem ser do tipo compressão ou curvamento, unidirecional ou reverso ${ }^{83}$. Em esquemas mais complexos, o espécime é submetido simultaneamente a forças torsionais. Essas máquinas são controladas por computador; então, virtualmente, qualquer espectro de carga pode ser gerado por pontas diferentes e um espécime pode receber uma combinação de cargas, com indução de pressões extremamente complexas ${ }^{107}$. Por outro lado, impor carga mecânica em uma estrutura protética em sentido unidirecional reproduzirá somente em parte as condições mecânicas do ambiente oral. Alguns autores têm relatado o uso de máquinas que reproduzem mais fielmente o ambiente oral, os chamados simuladores mecânicos de mastigação, pois mesclam a carga cíclica mecânica com a ciclagem térmica ${ }^{15,50,51,94}$ 
Na programação do teste de carga cíclica, a freqüência e quantidade de carga, geralmente, são baseadas em dados encontrados no ambiente oral, relatados na literatura. Se uma média de freqüência devesse ser estipulada, 80 ciclos por minuto seria considerada normal (em média $1,4 \mathrm{~Hz})^{10,60}$, uma vez que a velocidade de mastigação varia entre 49 a 120 ciclos por minuto. Ainda assim, a mais usada pela maioria dos autores se situa entre 1,3 e $2 \mathrm{~Hz}^{15,28,50,51,56,71,89,91,94}$. No aspecto de quantidade de ciclos, é assumido que ocorram 3 períodos de 15 minutos de mastigação por dia, a uma taxa de mastigação de 60 ciclos por minuto (o que equivale a $1 \mathrm{~Hz}$ ). A média individual de mastigação é calculada então em 2.700 vezes por dia. Essa quantidade equivale grosseiramente a $10^{6}$ ciclos por ano. Baseado nessa premissa, se a vida média de uma prótese parcial fixa é estipulada em 20 anos, essa prótese será submetida provavelmente a $2 \times 10^{7}$ ciclos mastigatórios. Mas, por outro lado, pode-se argumentar que nem todo ciclo mastigatório é ativo, ou seja, nem todo ciclo de estresse aplicado à estrutura protética tem amplitude máxima. Portanto, os $2 \times 10^{7}$ ciclos mastigatórios, previamente calculados, devem ser diminuídos por um fator que varia de 5 a 20 se um valor real é desejado. Baseado nesta matemática, para aplicações dentais, os testes com carga cíclica devem ser realizados por um mínimo de $10^{6}$ de ciclos ${ }^{107}$. Entretanto, um teste com carga cíclica com programação de 1,2 milhões de ciclos de carga de $30 \mathrm{~N}$ para dentes tratados endodonticamente restaurados com pinos pré-fabricados e núcleos de preenchimento cobertos com coroas totais, pode não causar diferenças significantes de valores de resistência em relação a espécimes não submetidos à fadiga ${ }^{52}$.

Outro aspecto a ser considerado na programação do teste de carga cíclica é o ângulo de incidência da carga no espécime, que também deve ser seguido para o posterior teste sob carga estática nos espécimes. Na maioria dos estudos in vitro usando carga estática, o ângulo usado para se incidir a carga nos espécimes é programado em $130^{\circ}$ a $135^{\circ} \mathrm{em}$ relação ao longo eixo dos dentes. Inclinações de $110^{\circ}$ e $130^{\circ}$ não produzem valores de resistência à carga de compressão estática diferentes entre si; em contrapartida, se comparados valores de resistência de dentes tratados endodonticamente reconstruídos com núcleos intra-radiculares e coroa total, submetidos à carga estática, quando se usa ângulo de $150^{\circ}$, este último gera valores de carga maiores. A homogeneidade na angulação de incidência de carga entre os trabalhos é crucial para a comparação de resultados com outros estudos ${ }^{52,67}$.

$\mathrm{Na}$ determinação do valor de carga a ser usada durante o teste de carga cíclica, não há uma concordância entre os trabalhos revisados. Alguns autores 
preferem utilizar valores de carga similares aos encontrados no ambiente oral $^{15,50,51,52,83}$, que variam de $30 \mathrm{~N}$ a $130 \mathrm{~N}^{60,107}$, fazendo uso também de estresse térmico associado, enquanto outros se preocupam em causar somente estresse mecânico nos espécimes ${ }^{28,40,71}$ utilizando valores de carga muito acima dos valores de mastigação normal, variando de $250 \mathrm{~N}$ a $400 \mathrm{~N}$. Estes últimos justificam o emprego de tais valores como forma de reproduzir o pior cenário encontrado no ambiente oral, ou seja, quando um indivíduo submete a restauração a forças parafuncionais.

\subsection{Estudos clínicos}

CREUGERS; MENTINK; KÄYSER ${ }^{26}$ realizaram uma meta-análise, em 1993, para revisar estudos clínicos de restaurações dentais sobre núcleos intraradiculares. O método para meta-análise usado foi o preconizado por L'abbé et al. Uma pesquisa de literatura foi feita pelos autores, para identificar os estudos entre 1970 a 1992.

Seguindo os objetivos do estudo, os critérios de inclusão e exclusão para selecionar os dados foram: (1) o período médio de acompanhamento deveria ser de pelo menos 5 anos; (2) a publicação deveria fornecer informações relevantes sobre os pacientes e o procedimento de seleção dos pacientes; (3) deveria haver informações suficientes sobre os sistemas de pinos intra-radiculares e núcleo de preenchimento; (4) deveria haver uma definição clara para o termo "falha"; (5) a publicação deveria apresentar os dados de sobrevida (incluindo informações censuradas) ou deveria conter informações apropriadas para calcular ou acessar dados de sobrevivência, incluindo intervalos de confiança.

Foram encontrados 16 artigos que continham dados confiáveis sobre pinos intra-radiculares e núcleos de preenchimento. Destes, 11 foram excluídos para análises posteriores. Foram constatadas, nesses 11 artigos, definições diferentes para "falhas". As restaurações de núcleos intra-radiculares foram consideradas falhas nos casos onde um ou mais dos seguintes eventos ocorreram: perda de retenção (recimentação), inserção de um novo núcleo intra-radicular (nova restauração), fratura da raiz ou extração do dente. O método Kaplan e Meier foi usado para reconstruir a curva de sobrevivência dos núcleos intra-radiculares em diferentes estudos.

Como resultado, foi obtido um ponto final de curva de sobrevivência, após 6 anos, de $81 \%$ para núcleo de preenchimento de resina composta em 
combinação com pinos intra-radiculares metálicos, e $91 \%$ para os 2 estudos que incluíam núcleos metálicos fundidos. Os estudos que relataram definições diferentes para "falha" apresentaram sobrevida com taxas que variaram de $77,6 \%$ de sobrevida após um acompanhamento de 5,2 anos, até $98,6 \%$ após acompanhamento de mais de 10 anos, dependendo do critério utilizado na definição de falha.

Em 1995, TORBJÖRNER; KARLSSON; ÖDMAN ${ }^{102}$ fizeram um estudo retrospectivo de 638 pacientes tratados com 788 núcleos intra-radiculares.

Como resultado, de 788 núcleos intra-radiculares foram registradas 72 falhas técnicas, com percentual de 2,1\% ao ano, ou taxa cumulativa de sucesso de $87,7 \%$ em 6 anos. Foram feitos 345 núcleos intra-radiculares em homens e 443 em mulheres. A taxa de falha cumulativa foi maior para homens $(15 \%)$ do que para mulheres $(10 \%)(p<0,05)$, e maior em idosos com mais de 60 anos $(24 \%)$ comparado com $8 \%$ para o grupo até 60 anos. A maioria dos núcleos intra-radiculares foi colocada na maxila, onde a taxa de falha cumulativa foi de $15 \%$ comparado com $5 \%$ na mandíbula. A taxa cumulativa de falha, em média, foi mais óbvia em dentes anteriores e foi observada também quando eles foram usados como pilares de próteses parciais fixas e próteses parciais removíveis. Fraturas de raízes, que ocorreram em 21 dentes, resultaram em extração. Houve maior freqüência de fraturas radiculares entre núcleos intra-radiculares cônicos do que nos núcleos intra-radiculares fundidos a partir de ParaPost ${ }^{\circledR}$. Os pilares de próteses parciais fixas demonstraram menor taxa de falha do que coroas unitárias e pilares de próteses parciais removíveis. A taxa de falhas para pilares distais de cantilevers foi maior do que outros pilares de próteses parciais fixas. Seis falhas foram registradas para 48 dentes pilares distais com extensão em cantilevers. As falhas ocorreram em prótese parcial fixa com 1 pôntico em cantilever enquanto os 4 pinos pré-fabricados com 2 cantilevers continuaram em função. Nesse estudo, 72 núcleos intra-radiculares foram classificados como mal-sucedidos, o que correspondeu a taxa de insucesso de $2,1 \%$ ao ano.

Considerando que os pinos intra-radiculares de resina composta reforçados por fibra oferecem boa característica de retenção intra-radicular pelo uso de cimentação resinosa, excelente adesão do cimento ao dente e ao pino, e do pino pré-fabricado com o material de núcleo de preenchimento, confecção em uma só sessão, além de facilidade de remoção do canal caso seja necessário, FREDRIKSSON et al. $^{36}$, em 1998, publicaram um estudo retrospectivo de 236 pacientes nos quais foi usada a técnica de restauração com pinos de resina epóxica reforçados por fibras de carbono. De um total de 236 pacientes (92 homens e 145 
mulheres), com idade variando de 31 a 88 anos, 146 pacientes concordaram em participar do reexame clínico. Os dados dos outros 90 pacientes foram obtidos de programa de revisão individual feito por outros dentistas que não da pesquisa, de 3 a 6 meses antes desta pesquisa. O tempo de serviço dos pinos resinosos reforçados com carbono foi de 27 a 41 meses, com média de 32 meses. As restaurações finais foram $80 \%$ de coroas metalo-cerâmicas, $10 \%$ de porcelana pura e o restante dos dentes restaurados com resina composta. Dos dentes opostos, $88 \%$ tinham prótese parcial fixa, $4 \%$ com prótese parcial removível, $4 \%$ ocluíam com dentes não restaurados e $4 \%$ não estavam em oclusão.

O sucesso foi julgado por exame clínico e radiografias intra-orais. Em 146 pacientes examinados, 117 dentes contralaterais estavam disponíveis para controle.

Dos 236 dentes tratados, 5 foram extraídos de 2 a 6 meses devido a periodontite severa, destruição periapical em volta da raiz e 2 por fraturas radiculares, e, portanto não foram considerados dentes perdidos. Não houve diferença quanto a índices de placa, de sangramento e gengival. Na medida de profundidade de bolsa, houve diferença entre os 2 tipos de núcleos intra-radiculares, com os núcleos convencionais apresentando índice maior de profundidade de bolsa do que os restaurados com pinos de resina composta reforçados por fibra de carbono Composipost. Nenhum deslocamento ou fratura de pinos ou raízes ou cáries foram observados nos 231 dentes remanescentes.

Em um estudo de acompanhamento de 3 anos, foi comparado o desempenho de dentes tratados endodonticamente reconstruídos com pinos intraradiculares de resina composta reforçados por fibra de carbono, tendo como restauração final coroas totais ou restaurações de resina composta, por MANNOCCI et al. $^{72}$, em 2002. Eles incluíram indivíduos com um pré-molar maxilar e um mandibular, para o quais estivessem indicados tratamento endodôntico e restauração com coroa total e que se encaixavam nos seguintes critérios de inclusão/exclusão: somente pré-molares com cavidade classe II e estruturas das cúspides preservadas, sem tratamento endodôntico prévio, em função oclusal após a restauração e não serem usados como pilar de PPR ou PPF. Não apresentar perda óssea maior do que 40\%; dentes com índice de sangramento grau 3 (espontâneo) foram excluídos. Dos 117 indivíduos incluídos (54 homens e 63 mulheres), a idade variou de 35 a 55 anos, com média de 48 anos. Foram incluídos 24 primeiros pré-molares superiores, 57 segundos pré-molares superiores, 31 pré-molares inferiores e 33 segundos pré- 
molares inferiores. Sessenta dentes foram incluídos no grupo de restaurações com resina composta, e 57 foram restaurados com coroas metalo-cerâmicas. Os núcleos intra-radiculares foram feitos por um único operador usando técnica adesiva. Os pinos intra-radiculares usados foram Composipost ${ }^{\circledR}$ e sistema adesivo cimento C\&B/All Bond $2^{\circledR}$. As causas de falha foram classificadas como fratura de raiz, de pinos intraradiculares e descimentação de pinos intra-radiculares ou evidência radiográfica de infiltração marginal entre dente e restauração, ou evidência clínica de contigüidade com as margens da restauração.

Nenhum dente foi perdido e no reexame de 1 ano não houve falhas. Após os reexames de 2 e 3 anos, houve descimentação de pinos intra-radiculares (1 no grupo 1 e 2 no grupo 2) e espaços marginais (3 para grupo 1 e 1 para grupo 2). Os autores citam não ter encontrado nenhuma diferença entre os dois grupos $(p<0,05)$, apesar de terem sido reexaminados 104 dentes após 3 anos e não terem sido explicadas as ausências dos outros indivíduos da pesquisa. Os autores citaram que a descimentação dos pinos intra-radiculares deve-se ao contato dos pinos através da sua extensão na superfície oclusal com água nos dentes restaurados somente com resina composta, o que causaria desagregamento das fibras de carbono da matriz de resina epóxica.

Com o objetivo de testar a hipótese de que a colocação de coroas totais (cobertura coronal) está associada com aumento de sobrevida de dentes em estudos clínicos controlados, quando outros fatores tais como problemas endodônticos, restaurações e pré-acessos são controlados, em 2002, AQUILINO; CAPLAN ${ }^{4}$ fizeram um estudo retrospectivo e uma análise de multivariância de riscos proporcionais para perda de dentes em estudos clínicos controlados.

Foram selecionados todos os dentes que receberam tratamento endodôntico entre 1985 e 1987 na Escola de Odontologia de lowa. A lista foi restrita aos pacientes com pelo menos 1 visita em intervalos tanto no período de 1985-1987 e 1995-1996, resultando 1089 dentes de 734 pacientes.

Os registros, radiografias e dados em computador dos pacientes foram analisados para definir as variáveis com relação à perda de dentes e para verificar se os critérios de inclusão/exclusão foram satisfatórios. Setenta dentes não satisfizeram os critérios de inclusão inicial; isso incluiu dentes que foram submetidos a tratamento endodôntico $(n=50)$, dentes sem dados registrados $(n=11)$, dentes com dados errados ou sem registro $(n=4)$, dentes com dados perdidos $(n=5)$. Dos 330 dentes restantes, 
cujos dados foram coletados, terceiros molares $(n=6)$ e dentes sem registro de restaurações definitivas $(n=18)$ foram excluídos da análise. Dentes que serviram como pilares de PPF $(n=24)$ e dentes que foram restaurados com coroas $(n=52)$ também foram excluídos pelas mesmas razões: a condição pré-operatória do remanescente coronário não poderia ser classificada, e a presença de coroa ou retentor para PPF necessitaria de que o dente fosse restaurado com coroa ou que funcionasse como pilar $(n=1)$. Dentes, cujas radiografias pré e pós-operatórias tivessem sido perdidas, também foram excluídos $(n=26)$.

Assim, 203 dentes tratados endodonticamente em 156 pacientes (88 mulheres e 68 homens com média de idade de $54 \pm 15,2$ anos) foram avaliados. A amostra incluiu 33 incisivos, 25 caninos, 72 pré-molares, 43 primeiros molares e 30 segundos molares. Lesões cariosas na época da análise, foram diagnosticadas através de radiografias periapicais, assim como pré-tratamento em 103 (50,7\%) dos 203 dentes. Noventa e cinco dentes foram restaurados com pinos pré-fabricados e núcleos de preenchimento ou núcleos metálicos fundidos, enquanto 108 dentes receberam núcleos de preenchimento de amálgama, resina composta ou ionômero de vidro sem pinos pré-fabricados. Após a terapia endodôntica, coroas foram instaladas em 129 dentes, enquanto em 74 dentes foram feitas restaurações definitivas com amálgama ou resina composta. Desse total referente à triagem inicial, $42(20,7 \%)$ dos 203 dentes no estudo controlado aleatório foram extraídos durante o período de acompanhamento (14 com coroas e 28 com restaurações diretas).

No resultado, foi avaliada a perda de dente, seguindo a data de acesso endodôntico. Para os dentes que foram extraídos subseqüentemente, o acompanhamento terminou na data de extração. As radiografias mais recentes foram examinadas para verificar as extrações ou falta dos dentes como documentado nos registros de tratamento.

A análise dos resultados mostrou que os dentes que tiveram restauração final com coroa, após tratamento endodôntico, tiveram significantemente maior tempo de sobrevida do que os dentes sem coroas $(p<0,0001)$. Ainda mais, $o$ número de contatos proximais na hora da análise foi significantemente associado com sobrevivência $(p<0,0001)$ : dentes com 2 contatos proximais tiveram melhor estimativa de sobrevivência do que dentes com 0 ou 1 contato proximal. Dentes com cáries dentais tiveram taxas de sobrevivência mais pobre em 5 e 10 anos do que dentes sem cáries ( $p<0,0016)$. $O$ efeito do tipo de dente foi analisado com 2 métodos diferentes. Primeiro, incisivos, caninos, pré-molares, primeiros molares, e segundos molares 
foram avaliados separadamente, e a análise mostrou não haver diferença de tipo de tratamento quanto à sobrevivência $(p=0,04)$. Pelo fato de os segundos molares terem uma pior taxa de sobrevivência do que os outros dentes, ao exame de 10 anos, foi feita comparação dos segundos molares com todos os outros dentes, em uma segunda análise, individualmente. Os segundos molares tiveram menor taxa de sobrevivência do que todos os outros tipos combinados $(p<0,007)$. $O$ tipo de fundação também teve associação significativa com sobrevivência: dentes que receberam pinos pré-fabricados demonstraram melhor taxa de sobrevivência do que os que não os receberam $(p=0,01)$. Finalmente, o tempo decorrido entre a obturação do canal e colocação do núcleo de preenchimento foi associada com sobrevivência $(p=0,02)$, com maior taxa de sobrevivência obtida por dentes que receberam núcleo de preenchimento oito ou mais dias após a obturação. Nenhuma outra variável foi associada com taxa de sobrevivência dos dentes incluídos neste estudo aleatório controlado. Dentes que não receberam coroa foram perdidos em uma proporção 4 vezes maior do que os dentes que não receberam coroas.

Em 2003, ELLNER; BERGENDAR; BERGMAN ${ }^{30}$ publicaram um estudo prospectivo de 10 anos de avaliação de comportamento de 4 tipos de núcleos intraradiculares: o grupo 1 recebeu núcleos metálicos fundidos $(n=14)$; o grupo 2 recebeu pinos pré-fabricados ParaPost ${ }^{\circledR}$ com núcleos de preenchimento fundidos $(n=13)$; o grupo 3 recebeu pinos pré-fabricados ParaPost ${ }^{\circledR}$ fundidos e o grupo 4 recebeu sistema Radix-Anchor $^{\circledR}(n=10)$, totalizando 50 dentes tratados endodonticamente em 31 pacientes distribuídos aleatoriamente nos 4 grupos. O grupo de pacientes foi constituído de 14 mulheres e 17 homens, com idade variando entre 16 e 75 anos. Os tratamentos foram realizados entre 1989 e 1993. Nos critérios de inclusão constaram: 1- um ou mais dentes unirradiculares que necessitassem de coroa individual que não fossem usados para suportar PPR; 2- nenhum sinal marcante de bruxismo (não especificado no trabalho) expressado como atrição pesada; um número limitado de facetas de desgaste nos dentes remanescentes foi aceito; 3- pelo menos $2 \mathrm{~mm}$ de dentina coronária para fornecer efeito de férula. No exame inicial avaliaram-se: 1cáries por exame clínico e radiográfico; 2- relação maxilo-mandibular sagital, transversa e vertical; 3- oclusal (qualquer interferência notada foi ajustada); 4- oclusão em excursões laterais; índice de placa, bolsa e sangramento; retração gengival, inchaço gengival; trincas nos dentes experimentais; condições periapicais. O espaço para os núcleos intra-radiculares foi de $8 \mathrm{~mm}$, com o objetivo de o comprimento de o pino ser igual à altura da coroa artificial, e que o selamento apical tivesse no mínimo 
$4 \mathrm{~mm}$. Os pacientes foram reexaminados regularmente até 1999. O exame final foi feito após um período entre 72 e 122 meses (média de 109 meses).

A taxa de falha geral foi de $6 \%$. Se o grupo 4 (Radix Anchor ${ }^{\circledR}$ ) fosse excluído, a taxa final seria $3 \%$ ao exame final. O grupo 1 teve 0 (zero) falhas $(n=14)$; o grupo 2 teve 1 falha ( $n=13)$; o grupo 3 não teve falhas; o grupo 4 teve 2 falhas $(n=10)$. Assim, dentre os 30 pacientes, 46 dos 49 núcleos intra-radiculares (94\%) continuavam em função após uma média de 103 meses, e não houve diferença entre os 4 grupos. Um detalhe observado é que 34 dos 50 núcleos intra-radiculares obedeceram à proporção coroa artificial/núcleo intra-radicular $\leq 1$.

Os autores não conseguiram encontrar nenhuma relação entre tamanho de pino intra-radicular/tamanho de coroa; tamanho pino intra-radicular/tamanho do dente; comprimento do pino intra-radicular protruindo para fora da coroa/comprimento pino intra-radicular, e comprimento do pino intra-radicular abaixo do nível ósseo.

Complicação é definida como uma "doença secundária ou condição desenvolvida no curso da doença ou condição primária". As complicações em próteses fixas foram objeto de interesse de GOODACRE et $\mathrm{al}^{44}$, em 2003, que fizeram uma revisão de literatura onde os critérios de inclusão foram: identificação do número de restaurações ou próteses avaliadas, quanto tempo de serviço clínico e quantos dentes foram afetados pelas complicações. As publicações foram agrupadas de acordo com o tipo de restauração/prótese. Os dados não tratados de restaurações, em particular, foram combinados e uma média de incidência de complicações foi calculada para cada tipo de restauração/prótese. Os valores médios foram comparados com o propósito de identificar quais grupos foram associados com maiores quantidades de complicações.

Para coroas unitárias, 1476 coroas foram avaliadas em 8 estudos, e um total de 157 foram associados com complicações resultando em 11\%. A duração dos estudos foi de 1 a 23 anos, com duração média de 6 anos. Para retratamento endodôntico, foram relatadas 27 de 823 coroas avaliadas, com média de incidência de $3 \%$ num intervalo de 0 a $6 \%$. A fratura de porcelana atingiu $9 \%$ de 199 coroas. Perda de retenção foi relatada em 19 coroas dentre 1061 avaliadas. Doença periodontal respondeu por $0,6 \%$ ou 6 coroas entre 986 avaliadas, e cáries foram responsáveis por $0,4 \%$ ou 4 em 1105 coroas avaliadas. 
$\mathrm{Na}$ análise de núcleos intra-radiculares foram avaliados 12 estudos clínicos, que relataram 279 (10\%) complicações dentre 2784 analisados. Dentre os 12 estudos avaliados, o período de observação foi de 1 a 25 anos, com média de 6 anos. As complicações mais comuns encontradas foram: 1- perda de núcleos intraradiculares de um total de 2596, sendo a incidência de 135 (5\% em média); 2- fratura de raízes, correspondendo a 3\% ou 95 de 3043 dentes avaliados; 3- cáries foram responsáveis por 16 falhas de 1047 dentes avaliados ou 2\%; 4- doença periodontal respondeu por 6 dentes em 283 ou $2 \%$ das falhas.

\subsection{Estudos in vitro}

Em 1979, GUZY; NICHOLLS ${ }^{46}$ compararam in vitro, a resistência de dentes tratados endodonticamente com e sem pinos intra-radiculares cimentados, com o propósito de determinar se os pinos intra-radiculares reforçariam realmente os dentes tratados endodonticamente. Foram utilizados 59 dentes, incisivos centrais e caninos, os quais tiveram seus condutos radiculares preenchidos com guta-percha, pela técnica da condensação lateral. Em 29 dentes, não foram utilizados pinos intraradiculares, e posteriormente foi removido $1 \mathrm{~mm}$ de material obturador, aquém de suas junções cemento-esmalte. Nessa região foi feita, então, restauração de silicato. Os outros 30 dentes receberam pinos intra-radiculares, tendo sido removido de 7 a $8 \mathrm{~mm}$ de material restaurador intra-canal; foram cimentados pinos intra-radiculares Kerr Endo-Post ${ }^{\circledR}$ com cimento de fosfato de zinco e uma broca foi usada para preparar uma cavidade lingual, a qual recebeu uma restauração de silicato. Uma carga foi incidida num ângulo de $130^{\circ}$, em relação ao longo eixo dos dentes, a uma velocidade de $5 \mathrm{~cm} / \mathrm{min}$, até fratura dos dentes. A análise dos resultados mostrou que não houve diferença estatística significante entre a média de carga aplicada para os dois grupos de dentes.

Com o propósito de determinar se há diferença na resistência à fratura em dentes reconstruídos com núcleos intra-radiculares submetidos à carga estática com diferentes ângulos de incidência, LONEY, MOULDING, RITSCO ${ }^{67}$, em 1995, usaram 30 incisivos centrais superiores que foram restaurados com núcleos metálicos fundidos a partir de ParaPost ${ }^{\circledR}$ plásticos, cimentados com cimento de fosfato de zinco e cobertos com coroas metálicas. Os dentes foram levados à máquina de testes universal e testados com ângulos de incidência de força diferentes em relação ao longo eixo dos dentes. No grupo 1 foi usado um ângulo de $110^{\circ}=372,4 \pm 140,8 \mathrm{~N}$; no 
grupo 2 , de $130^{\circ}=597,6 \pm 138,5 \mathrm{~N}$ e no grupo 3 , de $150^{\circ}=1274,3 \pm 429,9 \mathrm{~N}$. Houve diferença estatisticamente significante entre os grupos 3 e 1 e 2, mas não entre os grupos 1 e 2. As médias de carga aumentaram com o aumento do ângulo de incidência da carga.

DIETSCHI; ROMELLI; GORETTI ${ }^{28}$, em 1997, estudaram as interfaces entre restaurações e pinos intra-radiculares de diferentes sistemas de pinos intraradiculares, depois de teste com carga cíclica não destrutivo. Os grupos de sistemas de pinos intra-radiculares investigados foram: (1) Komet ${ }^{\circledR}$, de titânio tendo a cabeça recoberta por uma camada de agente opacificador e corpo jateado com óxido de alumínio, forma cônica, cabeça em forma de bola, com módulo de elasticidade=110; (2) Titânio coberto com plasma de alumínio de forma cônica com módulo de elasticidade=110; (3) Zircônia sinterizada estabilizada por dióxido de ítrio e jateada com óxido de alumínio, de forma cilíndrica com módulo de elasticidade = 200; (4) Resina epóxica com fibras de carbono, de paredes paralelas, com retenções mecânicas e resistência à tração = 90 e flexural = 8; (5) Experimental de resina epóxica reforçado por fibra, de paredes paralelas, com retenções mecânicas, com resistência flexural e à tração de $8,9 \mathrm{MPa}$ e $60 \mathrm{MPa}$, respectivamente. O autor cita o módulo de elasticidade da dentina coronária $=16,5-18,5 \mathrm{GPa}$, e o da dentina radicular $=18 \mathrm{GPa}$.

Foram utilizados 40 incisivos e caninos superiores obturados com cimento sem eugenol. As coroas foram reduzidas até a junção cemento-esmalte a fim de que fossem obtidas somente superfícies dentinárias para procedimentos adesivos. As raízes foram preparadas e, exceto para o grupo em que se utilizou o sistema Composipost $^{\circledR}$, os canais radiculares foram tratados com agente autocondicionante ED Primer $^{\circledR}$, cimento resinoso Panavia $21 \mathrm{EX}^{\circledR}$. A dentina foi tratada com ácido fosfórico a $37 \%$ por 10s, e Scotchbond Multipurpose ${ }^{\circledR}$ primer e adesivo. Os núcleos de preenchimento foram confeccionados com resina composta.

Para o grupo em que foi usado Composipost ${ }^{\circledR}$, as raízes foram condicionadas por 30s com EDTA, e uma camada de resina não polimerizada foi aplicada. Os núcleos de preenchimento foram feitos com resina composta. Não foram confeccionadas coroas. Os espécimes foram submetidos a 250.000 ciclos de carga mecânica, com uma força de $70 \mathrm{~N}$ a $1,5 \mathrm{~Hz}$ de freqüência, e 5000 ciclos térmicos de $5^{\circ} \mathrm{C}-55^{\circ} \mathrm{C}$. Foram obtidas réplicas em resina epóxica dos espécimes cortados, as 
quais foram avaliadas no microscópio eletrônico de varredura, num aumento de 250 vezes.

A interface núcleo de preenchimento/pino intra-radicular e pino intraradicular/agente cimentante e a interface núcleo de preenchimento/pino intra-radicular não apresentaram nenhum defeito de adesão. Na interface pino intra-radicular/agente cimentante houve deslocamento de $10,75 \%$ para o grupo dos pinos intra-radiculares de zircônia; na interface núcleo de preenchimento/dentina, o percentual de adesão em continuidade variou de $44,88 \%$ no grupo Composipost ${ }^{\circledR}$ a $83,88 \%$ no grupo Komet $^{\circledR}$. O grupo Komet ${ }^{\circledR}$ apresentou valores mais altos de continuidade de interface comparado às restaurações dos grupos Zircon e Experimental.

Somente as interfaces entre o material restaurador e a dentina demonstraram defeitos significantes; o pino intra-radicular de zircônia Komet ER $^{\circledR}$ exibiu a maior continuidade entre as interfaces coronais e radiculares, embora os espécimes nesse grupo apresentassem fraturas. Os autores concluíram que os pinos intra-radiculares de zircônia tiveram uma influência adversa na adaptação da interface entre o núcleo de preenchimento e pino intra-radicular/dentina, provavelmente resultado de sua alta rigidez; as propriedades mecânicas do Composipost ${ }^{\circledR}$, que são próximas às da dentina, pareceram ter sido benéficas nesse estudo; o uso de agentes de adesão dentinários pareceu ser mandatário para melhorar a adesão dos materiais usados à dentina.

Em 1998, MARTINEZ-INSUA et $\mathrm{al}^{73}$ compararam a resistência à fratura entre 2 tipos de tratamentos para dentes tratados endodonticamente: pinos préfabricados de resina epóxica/resina composta e núcleo metálico fundido. Foram usados 44 pré-molares em 2 grupos: 1- pinos pré-fabricados de resina epóxica com fibra de carbono; 2- núcleos metálicos fundidos. O tamanho e forma dos pinos foram idênticos nos dois grupos. Ambos foram restaurados com coroas totais metálicas. A resistência à fratura foi medida pela aplicação de carga em um angulo de $45^{\circ} \mathrm{em}$ relação ao longo eixo dos dentes. Os valores de resistência à fratura foram: grupo $1=103,5 \pm 31,0 \mathrm{~kg}$ e para o grupo $2=202,7 \pm 125,0 \mathrm{~kg}$, havendo diferença significante entre os dois. No grupo 2 as fraturas quase sempre afetaram os dentes, enquanto no grupo 1 os núcleos intra-radiculares quase sempre falharam primeiro. Os autores concluíram que apesar de os valores de fraturas serem mais altos no grupo 2, neste grupo ocorreu mais fratura de dentes que no grupo dos núcleos intra-radiculares de resina epóxica reforçados por fibra de carbono. 
Em 1999, GATEAU; SABEK; DAILEY ${ }^{40}$ investigaram o comportamento de três tipos de materiais de preenchimentos (amálgama de prata, ionômero de vidro reforçado com prata e resina composta) sob coroas artificiais metálicas, durante mastigação simulada, suportados por pinos intra-radiculares pré-fabricados metálicos.

Foram utilizados 75 primeiros pré-molares superiores pré-fabricados. Os pinos intra-radiculares foram cimentados com ionômero de vidro e núcleos de preenchimento foram confeccionados, sendo 25 de cada material. Coroas foram fundidas em liga básica e cimentadas com ionômero de vidro.

Os espécimes foram submetidos a uma carga de 400N por 1,5 milhão de ciclos.

As observações sob microscopia eletrônica de varredura evidenciaram fraturas iniciando-se nos pinos intra-radiculares, fraturas dentro do material, variação de separação ao longo dos pinos intra-radiculares, microinfiltração cervical e presença de porosidade. $\mathrm{Na}$ análise macroscópica, observou-se que nos corpos de prova de amálgama de prata não havia defeitos, enquanto que nos de resina composta os defeitos foram observados entre os núcleos de preenchimento e os pinos intraradiculares. Nos espécimes de ionômero de vidro ocorreram tanto fraturas entre o ionômero e o pino intra-radicular, como no corpo do ionômero. Os autores concluíram que quando submetidos à carga cíclica, dentes restaurados com pinos intraradiculares e núcleos de preenchimento, o material do núcleo de preenchimento mais resistente é o amálgama de prata seguido da resina composta, e do ionômero de vidro.

Em 1999, KOUTAYAS; KERN ${ }^{62}$ discorreram sobre os vários tipos de núcleos intra-radiculares totalmente cerâmicos, e dentre os 4 tipos possíveis, a técnica de termo-injeção de cerâmica vítrea aos pinos de cerâmica de zircônia é mais vantajosa do que as restaurações dos núcleos cerâmicos fundidos; são uniformes, com uma técnica familiar, ou seja, a técnica da cera perdida. A combinação de cerâmica vítrea e cerâmica de zircônia é possibilitada devido à similaridade de seus coeficientes de expansão térmica $\left(9,5 \pm 0,5 \times 10^{-6}\right.$ e $10,0 \pm 1,0 \times 1^{-6}$ respectivamente), que resultam em uma contração que propicia uma boa adaptação após o processo de termo-injeção. No entanto, os autores destacam que não é sabido se o processo de termo-injeção tem um efeito negativo na resistência dos pinos pré-fabricados de cerâmica de zircônia, pois a estrutura cristalina da zircônia é influenciada por grandes mudanças de temperatura. 
Para testar a taxa de sobrevivência de dentes tratados endodonticamente reconstruídos com pinos pré-fabricados estéticos, em 1999, MANNOCCI, FERRARI, WATSON ${ }^{71}$ utilizaram 4 grupos de 10 dentes reconstruídos com: resina composta reforçada com fibra de quartzo (grupo 1), resina composta reforçada com fibra de quartzo-carbono (grupo 2) e cerâmica de zircônia (grupo 3). O grupo-controle consistiu de raízes sem nenhum preparo de canal, nenhum pino intraradicular; somente $3 \mathrm{~mm}$ da parte coronária da guta-percha do canal foi removida (grupo 4). As coroas dos dentes dos grupos 1, 2 e 3 foram amputadas, deixando raízes com 14mm, e tomadas as dimensões vestíbulo-lingual e mésio-distal, e distribuídos nos diferentes grupos, de acordo com um método estratificado. Os condutos para os pinos pré-fabricados nos remanescentes dentais foram tratados com ácido fosfórico a $38 \%$ por 30 s, e secados levemente com ar comprimido. Os pinos intra-radiculares foram cimentados, e em seguida confecionados os núcleos de preenchimento em resina composta fotopolimerizável. Após 24 horas, foram feitos preparos para coroa total Empress ${ }^{\circledR}$. Nenhum remanescente dentinário coronário foi deixado para cumprir efeito de férula. A altura dos preparos foi de $5 \mathrm{~mm}$, e o término cervical de $1,5 \mathrm{~mm}$ de espessura. Após a cimentação das coroas com cimento resinoso, os espécimes foram deixados em água por 4 semanas. Os espécimes foram envolvidos em uma camada de silicone e montados em blocos de resina acrílica, deixando $6 \mathrm{~mm}$ de dente se estendendo além da resina (neste trabalho não é possível determinar a quantidade de remanescente radicular que ficou acima da margem de resina acrílica). Os espécimes foram submetidos a uma carga de $250 \mathrm{~N}$ a uma freqüência de $2 \mathrm{~Hz}$, por 400.000 ciclos, sob umidade. Foi determinada a curva de sobrevivência dos espécimes, as causas de falhas (fratura de raízes, fratura de coroas, fratura de pinos e descimentação da coroa ou pinos pré-fabricados). Os resultados mostraram que ocorreu 1 fratura de raiz e pino no grupo 1 e grupo 2, mas 6 fraturas no grupo 3 , sendo 1 em coroa e 5 com fraturas de raiz e pino. 0 grupo 4 teve fratura de raiz em todos os 10 espécimes. A curva de sobrevivência (pela análise Kaplan-Meier) foi significantemente menor no grupo-controle do que nos grupos experimentais; menor no grupo 3 do que nos grupos 1 e 2, mas nenhuma diferença entre as dos grupos 1 e 2 . Os autores consideraram que a técnica que utiliza os pinos de fibra de quartzo e carbono-quartzo com núcleo de preenchimento em resina composta restaurados com coroas Empress podem reduzir o risco de fratura das raízes restauradas. Todas as fraturas observadas nestes grupos foram acima da margem de resina acrílica, sendo consideradas favoráveis, uma vez que os espécimes poderiam ser restaurados. Os autores ainda justificam o uso de carga de $250 \mathrm{~N}$, o que excede as forças normais de mastigação, pois assim seria possível a comparação com 
outros trabalhos onde foram usados os mesmo pinos e ciclagem mecânica (não citados no texto). Outro fato a ser considerado no trabalho é que os autores extrapolam a indicação dos sistemas de pinos pré-fabricados e núcleo de preenchimento, não deixando nenhum remanescente coronário nos dentes usados como espécimes. Tentam também explicar os tipos de fraturas ocorridas no estudo, sugerindo que o módulo de elasticidade dos pinos de resina reforçados por fibra tenha valor mais próximo do módulo de elasticidade da dentina (em torno de 18MPa), contrariamente ao dos pinos de zircônia que têm valores da ordem de 200MPa.

Em 2001, FERNANDES; DESSA ${ }^{31}$ fizeram uma revisão, tanto trabalhos de laboratório quanto os estudos clínicos, dos fatores que afetam a resistência à fratura de dentes reconstruídos com núcleos intra-radiculares, e citaram:

1. Tamanho da porção intra-radicular do núcleo intra-radicular com exceção de um estudo laboratorial, todos os outros concordaram que uma extensão intra-radicular igual ou maior do que a coroa aumentava a taxa de sucesso dos dentes tratados endodonticamente. Também é aconselhado que o ápice do pino seja colocado além da crista óssea e o mais profundo possível na raiz, ou seja, na parte em que a raiz é suportada pelo osso. A extensão do pino também a $2 / 3$ do remanescente diminui o estresse no terço cervical da raiz.

2. Diâmetro do pino intra-radicular e remanescente dental - há um consenso de que a preservação de dentina residual é de suma importância. Remanescentes dentais com grande perda de estrutura e paredes alargadas podem ter benefícios de reforço com resina composta.

3. Desenho do pino intra-radicular - supõe-se que os pinos cônicos ou com uma extremidade cônica causam efeito de cunha. Alguns autores advogam que os pinos de paredes paralelas dispersam o estresse uniformemente, exceto no ápice, onde concentram estresse, devido aos ângulos vivos dessa extremidade do pino, remoção de estrutura e assentamento do pino nesta região.

Os pinos rosqueáveis causam padrões de estresse indesejáveis. No entanto, técnicas como pré-rosqueamento nos canais, limitação do número de roscas e contra-rotacionar o pino em 1/2 volta após total rosqueamento são as soluções preconizadas. Os pinos serrilhados com paredes paralelas produzem menos estresse e menor freqüência de fratura. 
4. Material dos pinos pré-fabricados - os autores sustentam que existe uma correlação bem definida entre o tipo de material do pino pré-fabricado e fratura de raízes. O material dos pinos deve ter o mesmo módulo de elasticidade da dentina radicular para distribuir as forças aplicadas uniformemente ao longo do comprimento do pino e da raiz. No entanto, quanto mais rígido o material, mais apto a resistir às forças sem distorção. O componente menos rígido falha e alivia o estresse.

As propriedades óticas dos pinos pré-fabricados de zircônia e de resina composta reforçados com fibra de vidro os indicam para casos estéticos. Os dentes tratados endodonticamente restaurados com pinos pré-fabricados metálicos mostram menos resistência do que os restaurados com pinos intra-radiculares de resina epóxica reforçados por fibra de carbono. Isso provavelmente, devido a maior rigidez, que causa concentração de estresse e leva à fratura radicular.

5. Agente de cimentação - a camada de cimento pode ser considerada uma camada de amortecimento, que contribui para a distribuição uniforme do estresse. A friabilidade e baixa resistência do cimento afetam a resistência à fratura dos dentes tratados endodonticamente, pois se fraturam na região cervical causando concentração de estresse apical, levando à fratura da raiz. Os cimentos resinosos se aderem efetivamente aos pinos e ao canal. A técnica de cimentação utilizando broca de lentulo é a melhor, pois cria uma camada uniforme, sem bolhas, o que distribui o estresse uniformemente.

6. Material do núcleo de preenchimento - o módulo de elasticidade afeta a distribuição do estresse. Os núcleos de preenchimento mais rígidos aumentam o estresse cervical e diminuem o estresse apical, pois inibem a intrusão do pino. Sob carga cíclica, os núcleos de preenchimento em resina composta propiciam melhores resultados do que os de ionômero de vidro, e ainda permitem melhor retenção dos pinos com técnicas adesivas.

7. Desenho da coroa - o efeito de férula ou abraçamento melhora a integridade dos dentes tratados endodonticamente. Considera-se que seu efeito antagoniza o braço de forças funcionais, o efeito de cunha dos pinos cônicos e as forças laterais exercidas durante inserção dos pinos e a função mastigatória dos dentes tratados endodonticamente. Os tamanhos considerados adequados variam de 1 a $2 \mathrm{~mm}$ de estrutura coronária acima da margem do término da coroa.

8. Biocompatibilidade - a resistência à corrosão deve ser considerada. Alguns relatos têm ligado a fratura radicular à corrosão de pinos pré- 
fabricados. O início da corrosão dos pinos se dá pelo acesso dos eletrólitos a eles. Esse acesso ocorre via cemento e via dentina na superfície radicular, uma vez que ambos os materiais são permeáveis à água e à solução de saliva. Uma segunda hipótese é via microinfiltração na restauração, e a terceira hipótese é que seja devido à fratura da raiz, produzida durante o preparo dos pinos ou cimentação deste. De todas as ligas, as de titânio são as que sofrem menos corrosão, mas são menos resistentes do que as de aço inoxidável ou liga de CrCo.

9. Posição do dente - os dentes anteriores estão expostos a forças transversais e, portanto, é aconselhável prover resistência pela preservação de estrutura e efeito de férula como parte do núcleo de preenchimento.

10. Dentes tratados endodonticamente como pilar de próteses parciais removíveis e fixas - dentes tratados endodonticamente têm um reduzido nível de propriocepção (nocicepção). Isso poderia desabilitar reflexos protetores normais quando forças destrutivas são aplicadas. É sugerido que dentes tratados endodonticamente e reconstruídos com núcleos intra-radiculares sejam contraindicados como pilares próteses parciais em cantilevers.

11. Métodos de estudos in vitro e sua significância clínica - a aplicação direta de resultados de estudos onde são usados modelos de fotoelasticidade e elemento finito é muito limitada, uma vez que as propriedades das estruturas simuladas, tais como isotropia, homogeneidade e elasticidade linear não é usualmente uma representação absoluta da estrutura. Em realidade, as estruturas modeladas (osso, dente, sistema do núcleo intra-radicular e coroa) são muito mais dinâmicas. Ainda, as características físicas dos tecidos variam de local para local e de indivíduo para indivíduo. Os estudos in vitro com dentes extraídos são afetados pelas variações nos dentes. Mudanças dentinárias podem ser causadas pelo conteúdo de água, condições pulpares pré-extração, idade do paciente, composição da dentina. Estes fatores afetam elasticidade do dente mudando os padrões de fratura durante a carga. O material onde os dentes são montados, geralmente resina acrílica ou gesso, não reproduzem as condições bucais, onde o osso é elástico, e há a presença de ligamento periodontal. Estudos mais recentes têm tentado simular este último, mas sua exata natureza não pode ser reproduzida.

Muitos estudos in vitro têm utilizado forças aplicadas diretamente, tanto na cabeça do pino quanto no núcleo de preenchimento. A coroa quando confeccionada sobre uma férula distribui forças ao núcleo intra-radicular e raiz 
diferente do que diretamente ao pino intra-radicular ou núcleo de preenchimento. As cargas das máquinas de testes universais não reproduzem forças oblíquas, torsionais e laterais de cisalhamento produzidas na mastigação.

12. Considerações práticas - os autores expõem fatores a serem considerados para se assegurar longo termo de serviço dos dentes tratados endodonticamente:

a) o comprimento deve ser o maior possível sem enfraquecer 0 selamento apical ou perfurar a raiz.

b) deve ser escolhido o menor diâmetro do pino intra-radicular para preservar o máximo de dentina, e ao mesmo tempo, prover resistência.

c) o pino intra-radicular deve ter lados paralelos, ser serrilhado, com canal de escape para o cimento, passivo e bem adaptado ao canal.

d) dos materiais, o titânio é o mais biocompatível. Experimentos clínicos de longo prazo com pinos intra-radiculares de resina composta reforçados por fibra e cerâmica de zircônia não estão ainda disponíveis.

Para comparar a resistência à fratura e o modo de fratura de raízes tratadas com núcleos metálicos fundidos, pinos intra-radiculares e núcleos de preenchimento em resina composta, e pinos intra-radiculares de resina composta reforçados por fibra e núcleo de preenchimento em resina composta, RAYGOT; CHAI; JAMESON $^{91}$, em 2001, usaram 30 incisivos centrais superiores, obturados com cimento à base de eugenol e guta-percha, divididos em 3 grupos de 10: grupo 1= restaurados com pinos intra-radiculares de resina composta reforçados por fibra, de 1,4mm de diâmetro/ resina composta; grupo 2= restaurados com ParaPost, de 1,5mm de diâmetro / resina composta; O grupo 3 foi restaurado com pinos intra-radiculares de paredes paralelas, de $1,5 \mathrm{~mm}$ de diâmetro, fundidos em metal nobre.

Os dentes foram amputados ao nível da junção cemento-esmalte e os canais preparados com $10 \mathrm{~mm}$ de profundidade. Foram incluídos em resina acrílica, deixando $4 \mathrm{~mm}$ de dentes expostos acima desta, até o limite da junção cementoesmalte. O término do preparo ficou $1 \mathrm{~mm}$ abaixo da junção cemento-esmalte, provendo $1 \mathrm{~mm}$ de efeito de férula e $1 \mathrm{~mm}$ de largura no ombro. As coroas metálicas foram cimentadas com fosfato de zinco. Os espécimes foram levados a uma máquina de testes universal, e uma carga foi aplicada até a fratura, numa velocidade de 
$25,4 \mathrm{~mm} / \mathrm{min}$ incidindo em um ângulo $130^{\circ}$ em relação ao longo eixo dos dentes. $\mathrm{Na}$ análise de resistência à fratura, não houve diferença significativa entre o grupo dos núcleos metálicos fundidos $(374 \pm 104 N)$, o grupo dos pinos intra-radiculares de resina composta reforçado por fibra $(307 \pm 33 \mathrm{~N})$ e o grupo de pinos intra-radiculares de aço inoxidável $(305 \pm 47 \mathrm{~N})$.

Todos os espécimes falharam por fratura de raiz. Entre $70 \%$ e $80 \%$ dos dentes dos 3 grupos mostraram fraturas favoráveis, ou seja, localizadas acima do nível da resina acrílica.

A infiltração das margens cervicais pode ser influenciada pela orientação dos túbulos dentinários nesta região que, determinam aí, a espessura da camada híbrida. FERRARI et al. ${ }^{33}$, em 2001, investigaram o efeito dos preparos para coroas na orientação dos túbulos dentinários, na resistência de adesão das resinas, e se houve aumento do número de desses após o condicionamento ácido no cemento e na dentina periférica, através do mapeamento da morfologia dos túbulos dentinários em dentes preparados para coroas de porcelana pura. Ainda, a influência da orientação tubular, sua densidade na camada híbrida e formação dos prolongamentos, além de identificar áreas onde os problemas relacionados à adesão podem ser esperados.

Para mapear os preparos para coroas, quantitativamente e qualitativamente, e avaliar a formação da camada híbrida juntamente com a penetração do sistema adesivo no cemento, os autores utilizaram três diferentes protocolos: 1- observação direta das paredes de dentes pilares preparados. 2observação da formação da camada híbrida entre o preparo para coroa em porcelana pura e o sistema adesivo; 3- observação dos prolongamentos do adesivo quanto à densidade e morfologia. Os autores usaram trinta dentes anteriores e trinta posteriores (15 incisivos centrais superiores, 15 caninos superiores, 15 segundos pré-molares e 15 primeiros molares), de pacientes com idade média de 59 anos (43-73 anos). Os dentes foram preparados com ponta diamantada e irrigação abundante, deixando chanfro de $1,5 \mathrm{~mm}$ na margem cervical, com redução de $1,5 \mathrm{~mm}$ nas paredes axiais e $2 \mathrm{~mm}$ na superfície oclusal e incisal. As margens cervicais foram extendidas $1 \mathrm{~mm}$ abaixo da junção cemento-esmalte. Os dentes foram aleatoriamente divididos em 6 grupos de 10 dentes, sendo 1,2 e 3 composto por anteriores e 4,5 e 6, por posteriores. Os grupos 1 e 4 foram levados ao microscópio eletrônico de varredura para observação e mapeamento da morfologia dos túbulos dentinários no preparo; os grupos 2 e 5 foram usados para avaliar a formação da camada híbrida entre dentina 
tratada e sistema adesivo; os grupos 3 e 6 foram usados para se observar a formação e morfologia dos prolongamentos de resina dentro dos túbulos.

Os espécimes do grupo 1 e 4 foram condicionados com ácido fosfórico a $32 \%$, por $15 \mathrm{~s}$, secados por $15 \mathrm{~s}$ e posteriormente metalizados com uma camada de ouro. Foram tomadas fotomicrografias das paredes cervical, oclusal, incisal e axiais em intervalos de $200 \mu \mathrm{m}$, começando da parede cervical e dirigindo-se para as paredes axiais. $\mathrm{Na}$ área do chanfro, a densidade dos túbulos foi calculada a cada $100 \mu \mathrm{m}$, começando da margem cervical e se movendo para a parede axial pelos primeiros $500 \mu \mathrm{m}$ e então a $1 \mathrm{~mm}$ da margem cervical. Na superfície foi tomada apenas 1 foto. $\mathrm{Na}$ superfície axial as fotomicrografias foram tomadas a 1 e $3 \mathrm{~mm}$ do ângulo áxio-pulpar em direção oclusal nos sentidos lingual, vestibular, mesial e distal para avaliar a densidade tubular. Os túbulos dentinários foram contados por meio de um aumento de 1000X, independente de sua direção. As fotos foram lidas através do método duplo cego. Ainda, nesses grupos foi medida a espessura da dentina remanescente, sendo considerada a distância direta da porção mais próxima da câmara pulpar e o sítioteste, medida com micrômetro.

Nos grupos 2, 3, 5 e 6, os espécimes foram tratados com ácido fosfórico a $32 \%$ e sistema adesivo (Scotchbond Multipurpose Plus ${ }^{\circledR}$ ) seguido de cobertura com resina composta fotopolimerizável $Z 100^{\circledR}$. Os espécimes dos grupo 2 e 5 foram, então, fraturados no longo eixo e no sentido vestíbulo-lingual, e cada secção foi desmineralizada com ácido fosfórico a $32 \%$ por $15 \mathrm{~s}$. Em seguida, foram desproteinizados por imersão em hipoclorito de sódio a $1 \%$ por 60 s. Os espécimes do grupo 3 e 6 foram mantidos em solução de hipoclorito de sódio por 2 dias, até completa dissolução da estrutura dentária, para que fossem observadas a densidade e morfologia dos prolongamentos resinosos. Para tanto, foram metalizados com uma camada de ouro e levados ao microscópio eletrônico de varredura. A espessura da camada de resina infiltrada foi avaliada em 8 regiões diferentes. Os resultados mostraram que a região $1 \mathrm{~mm}$ abaixo da junção cemento-esmalte consiste de uma camada relativamente espessa, sem aberturas tubulares, a qual foi superficialmente coberta por uma camada fina de cemento ao longo do comprimento integral da margem cervical. Examinando a parede gengival em direção interna, a partir da margem cervical, túbulos cortados perpendicularmente eram claramente visíveis. A largura da camada externa atubular foi maior nas regiões proximais do que em todos os setores vestibular e lingual. Os dentes anteriores apresentaram maior densidade de túbulos do que os posteriores. A densidade tubular na oclusal e a $1 \mathrm{~mm}$ da margem 
cervical foi maior do que nos outros locais avaliados. Na parede gengival, os túbulos aumentaram de densidade a partir da margem em direção à parede axial. No primeiro $1 \mathrm{~mm}$ quase não foram achados túbulos. A partir daí foram aumentando progressivamente. Não houve diferença entre os grupos 1 e 4 nos primeiros $100 \mu \mathrm{m}$, $200 \mu \mathrm{m}$ e $300 \mu \mathrm{m}$, assim como entre $200 \mu \mathrm{m}$ do grupo 2 e a $3 \mathrm{~mm}$ das paredes axiais e ângulo axio-pulpar do grupo 1, de 1 e $3 \mathrm{~mm}$ aquém do ângulo gêngivo-axial do grupo 1 e as mesmas regiões do grupo 4. Diferenças foram encontradas quando comparados todos os outros setores entre si.

Nas áreas com baixa densidade tubular, nos grupos 2 e $5(100 \mu m$ e $200 \mu \mathrm{m}$ da margem cervical), e nos setores com túbulos de orientação oblíqua ou paralela (3mm acima do ângulo gêngivo-axial), a camada híbrida foi mais fina (1,0$1,2 \mu \mathrm{m})$ do que nos outros setores, e os prolongamentos resinosos estavam ausentes ou não regularmente dispostos. Em áreas com corte de túbulos perpendicular e alta densidade tubular $(300 \mu \mathrm{m}$ e $400 \mu \mathrm{m}$ e $500 \mu \mathrm{m}$ da margem cervical, oclusal e $1 \mathrm{~mm}$ do ângulo gêngivo-axial), a espessura da camada híbrida foi entre $3,2 \mu \mathrm{m}$ e $5,5 \mu \mathrm{m}$. Nessas áreas, foram encontrados prolongamentos resinosos longos.

Os prolongamentos resinosos do grupo 3 e grupo 6 confirmaram as observações dos grupos 1 e grupo 4. Em geral, nenhum prolongamento resinoso foi detectado perto da margem cervical. A densidade dos prolongamentos resinosos foi diretamente correlacionada com a densidade tubular. A morfologia dos prolongamentos resinosos característicos, com formações laterais, foi a mais notada. Os autores concluíram que: 1- quando a margem cervical de um pilar é colocada abaixo da junção cemento-esmalte, uma camada externa não dentinária e uma camada de cemento formam parte da margem cervical; 2- após o tratamento com sistema de adesivo dentinário, a camada de aumento pode ser infiltrada pela resina, mas não em toda a extensão de dentina tratada pelo ácido; 3- a densidade e direção dos túbulos influenciaram a eficácia de adesão do sistema adesivo na dentina e 4- a morfologia dentinária dos pilares é grandemente previsível.

Com o propósito de investigar o comportamento de pinos pré-fabricados de titânio e cerâmica de zircônia com resina composta como núcleo de preenchimento, os pinos pré-fabricados de cerâmica de zircônia com cerâmica vítrea como núcleo de preenchimento e núcleo metálico fundido, sob fadiga termodinâmica, quanto à taxa de sobrevivência dos espécimes e modo de falha, BUTZ et al. ${ }^{15}$, em 2001, utilizaram 64 incisivos centrais superiores, dos quais foram removidas as coroas $2 \mathrm{~mm}$ acima da junção cemento-esmalte. Os canais foram obturados com guta-percha e cimento 
resinoso. Foram constituídos 4 grupos: grupo 1=pinos pré-fabricados de titânio/resina composta; grupo 2= pinos pré-fabricados de cerâmica de zircônia/resina composta; grupo 3=pinos pré-fabricados de cerâmica de zircônia/cerâmica vítrea termo-injetada e grupo 4=núcleos metálicos fundidos. As superfícies de todos os pinos pré-fabricados foram jateadas com óxido de alumínio $50 \mu \mathrm{m}$. Em todos os grupos, os pinos intraradiculares foram cimentados com resina composta. Os núcleos de preenchimento foram feitos com resina composta. A altura do núcleo de preenchimento foi de $4 \mathrm{~mm}$ nas superfícies proximais e $6 \mathrm{~mm}$ na vestibular. A extensão intra-radicular foi até $3 \mathrm{~mm}$ do ápice de cada dente, estabelecendo tamanhos variados de núcleos intraradiculares.

Todos os núcleos intra-radiculares foram cobertos por coroas metálicas e cimentadas com ionômero de vidro. As raízes foram cobertas desde $2 \mathrm{~mm}$ abaixo da linha de término da coroa, com silicone, para simular ligamento periodontal e incluídos em resina acrílica. Os espécimes foram submetidos a 1,2 milhão de ciclos de carga, sendo a força aplicada a $3 \mathrm{~mm}$ abaixo da borda incisal na superfície palatina, com uma freqüência de $1,3 \mathrm{~Hz}$, com uma força de $30 \mathrm{~N}$, incidindo em um angulo de $130^{\circ} \mathrm{em}$ relação ao longo eixo dos dentes, simultaneamente à ciclagem térmica que variou de $5^{\circ}$ a $55^{\circ} \mathrm{C}$, por $60 \mathrm{~s}$, com intervalo de $12 \mathrm{~s}$, por $10,000 \mathrm{X}$. Todos os espécimes que não fraturaram durante o teste de carga cíclica foram submetidos à carga estática até falha a uma velocidade de deslocamento de $1,5 \mathrm{~mm} / \mathrm{min}$, a um ângulo de $130^{\circ}$. O modo de fratura também foi analisado e classificado como reparável e não reparável. Para os espécimes que fraturaram no teste de carga cíclica foi designado valor igual a 0(zero) na análise estatística. Como resultado, 1 espécime do grupo 1, 6 do grupo 2, 0 do grupo 3 e 1 do grupo 4 falharam durante o teste de carga cíclica. Os grupos 1, 3 e 4 mostraram valores iguais entre si e superiores aos do grupo 2. Os padrões de fratura nos grupos 1 e 4 foram similares, com somente 1 fratura oblíqua. Todos os pinos préfabricados de titânio permaneceram intactos. O padrão no grupo 2 foi variado. Todos os pinos fraturaram e as fraturas geralmente envolveram o terço incisal abaixo da coroa, com a maioria delas envolvendo o núcleo de preenchimento em resina composta, se estendendo na superfície mesial da raiz, abaixo da margem da coroa. No grupo 3, todas as fraturas envolveram o terço incisal dos dentes e todos os núcleos de preenchimento foram separados dos pinos. Todos os pinos fraturaram, mas as fraturas raramente se estenderam abaixo da margem da coroa. No grupo-controle (4), todas as fraturas foram oblíquas e envolveram as raízes. Todos os núcleos intraradiculares metálicos permaneceram intactos. As fraturas não envolveram as porções coronárias dos dentes recobertas pelas coroas. 
Os autores concluíram que os pinos pré-fabricados de cerâmica de zircônia, com resina composta como núcleo de preenchimento, não devem ser indicados para uso clínico.

Uma análise de estudos clínicos sobre dentes restaurados com sistemas de pinos pré-fabricados/núcleos de preenchimento, publicada em 1970, relata taxas de sobrevivência de $98,6 \%$ depois de um acompanhamento de mais de 10 anos, até $77,6 \%$ após um período de 5,2 anos. Essa variação extrema de longevidade dos diferentes tratamentos pode refletir variações em materiais e técnicas ou pode ser relacionada a limitações em estudos clínicos e à falta de critérios de avaliação bem padronizados. Em 2001, STRUB; PONTIUS; KOUTAYAS ${ }^{94}$ compararam a taxa de sobrevivência e resistência à fratura de incisivos centrais superiores $(n=40)$ tratados endodonticamente. As coroas foram amputadas $2 \mathrm{~mm}$ acima da junção cementoesmalte. Os canais foram desobstruídos, deixando-se $5 \mathrm{~mm}$ de material obturador e os dentes distribuídos em 4 grupos de acordo com os pinos pré-fabricados. Grupo 1 pinos intra-radiculares pré-fabricados Permador $^{\circledR}$ e núcleo de preenchimento fundidos em metal cimentados com fosfato de zinco. No grupo 2, foram usados pinos intraradiculares de cerâmica de zircônia, cimentados com Panavia $\mathrm{TC}^{\circledR} / \mathrm{Scotchbond}$ Multipurpose ${ }^{\circledR}$ e Ceracap ${ }^{\circledR}$ como núcleo de preenchimento, cimentados aos pinos com resina composta. No grupo 3, pinos intra-radiculares de resina composta reforçados por fibra com infusão de cerâmica foram maquinados, cimentados com Panavia $\mathrm{TC}^{\circledR} /$ Scotchbond Multipurpose ${ }^{\circledR}$. No grupo 4 , foram usados os pinos intra-radiculares de cerâmica de zircônia e núcleos de preenchimento termo-injetados com porcelana vítrea. Copings de coroa de porcelana pura Procera All-Ceram ${ }^{\circledR}$ com espessura de $0,6 \mathrm{~mm}$ foram cimentados nos preparos, usando Panavia $\mathrm{TC}^{\circledR} /$ Scotchbond Multipurpose ${ }^{\circledR}$. Os espécimes foram incluídos em resina acrílica, simulando espaço biológico de $3 \mathrm{~mm}$, e levados a um simulador de ambiente oral, submetidos a 1.200 .000 ciclos a uma carga de $30 \mathrm{~N}$, incidindo num ângulo de $135^{\circ} \mathrm{com}$ o longo eixo dos dentes, $2 \mathrm{~mm}$ abaixo da margem incisal, e em seguida levados a uma máquina de testes universal e submetidos a uma carga estática com um deslocamento de $0,5 \mathrm{~mm} / \mathrm{min}$ até a fratura.

Sete dos 40 espécimes fraturaram parcialmente ou totalmente durante a carga cíclica. A taxa de sobrevivência foi de $90 \%$ para o grupo 1, 80\% para o grupo 2 , $60 \%$ para o grupo 3 e 100\% para o grupo 4. Quatro espécimes do grupo 3 não foram levados à máquina de testes universal devido à fratura do núcleo intra-radicular ou do coping. A média de resistência residual $(\mathrm{N})$ à fratura sob carga estática foi: grupo 
$1=1270 \pm 312,5$; grupo $2=1494,5 \pm 333,5$; grupo $3=1146,7 \pm 182,6$ e grupo $4=463,3 \pm 46,2$. A média de valores de resistência do grupo 4 foi significantemente menor do que a dos outros grupos, no entanto, os autores concluíram que seu valor de resistência média foi 1 1/2 maior do que o nível clínico necessário de $290 \mathrm{~N}$, que incide nos dentes anteriores in vivo.

Os autores concluíram que os pinos pré-fabricados de cerâmica de zircônia com núcleo de preenchimento de resina composta podem ser indicados para uso na clínica.

Em 2002, OTTL; LAUER; FAY ${ }^{84}$ compararam as características de fratura de dentes restaurados com 7 sistemas de núcleos intra-radiculares, usando incisivos centrais superiores feitos de resina composta Estilux Posterior VS ${ }^{\circledR}$, com tamanho dos canais de $9 \mathrm{~mm}$. No grupo 1, foram usados pinos intra-radiculares e núcleo de preenchimento metálicos em liga nobre; no grupo 2, pinos intra-radiculares e núcleos de preenchimento metálicos em liga básica; no grupo 3, pinos intra-radiculares metálicos à base de platina/irídio e núcleo de preenchimento em liga básica. No grupo 4 , foram usados pinos intra-radiculares de platina/irídio e núcleo de preenchimento em liga básica. No grupo 5, usaram-se pinos intra-radiculares de cerâmica de zircônia e núcleo de preenchimento em resina composta; no grupo 6 , foram usados núcleos intra-radiculares usinados a partir de blocos de alumina pré-sinterizados. No grupo 7, foram usados pinos intra-radiculares de liga básica e núcleo de preenchimento em cerâmica feldspática e no grupo 8 foram usados pinos de resina epóxica reforçados por fibras de carbono e núcleo de preenchimento em resina composta. Todos os pinos intra-radiculares foram tratados com sistema Rocatec ${ }^{\circledR}$ e cimentados, assim como as coroas metálicas com Panavia $21 \mathrm{TC}^{\circledR}$. No grupo-controle os dentes tratados endodonticamente com guta-percha e cimento, e receberam coroas, assim como os outros grupos. Os espécimes foram envoltos com elastômero, incluídos em resina acrílica e levados a uma máquina de testes universal, onde uma força foi aplicada num ângulo de $135^{\circ}$ em relação aos longos eixos, a uma velocidade de $0,5 \mathrm{~mm} / \mathrm{min}$, até a fratura. Os dentes foram incluídos até $3 \mathrm{~mm}$ aquém da linha de término das coroas. $A$ carga incidiu $2 \mathrm{~mm}$ abaixo da borda incisal. Os valores (em $\mathrm{N}$ ) de resistência foram: grupo $1=265,9 \pm 47$; grupo $2=288,7 \pm 91,2$; grupo $3=300,4 \pm 70,2$; grupo $4=242,3 \pm 60,9$; grupo 5=193,5 $\pm 57,0$; grupo 6=300,3 $\pm 89,3$; grupo $7=208,0 \pm 67,8$; grupo $8=312,5 \pm 58,8$ e grupo $9=228,8 \pm 35,7$. 
Houve diferença entre os grupos 1 e 6 , sendo os grupos 3 e 5 os de maior resistência.

AKKAYAN; GÜLMEZ, em $2002^{2}$, compararam o efeito de três sistemas de pinos estéticos e um sistema de pinos de titânio quanto à resistência e modo de fratura de dentes tratados endodonticamente, restaurados com coroas totais. Foram utilizados 40 caninos superiores, que tiveram suas coroas removidas, tratados endodonticamente, divididos em quatro grupos de 10, de acordo com distribuição estratificada. As dimensões dos remanescentes foram tratadas estatisticamente com ANOVA a 1 critério, para demonstrar não haver diferenças entre os grupos. Os dentes foram restaurados com pinos de titânio de 1,6mm de diâmetro (grupo 1), pinos intraradiculares de resina composta reforçados por fibra de quartzo de forma cônica, com diâmetro coronário de $1,7 \mathrm{~mm}$ e apical de $1 \mathrm{~mm}$ (grupo 2), pinos intra-radiculares de resina composta reforçados por fibra de vidro de $1,5 \mathrm{~mm}$ de diâmetro (grupo 3 ) e pinos de cerâmica de zircônia com 1,7m de comprimento, de forma cilíndrica com extremidade cônica (grupo 4). O tamanho de todos os pinos foi $11 \mathrm{~mm}$ e cimentados com o sistema adesivo Single Bond ${ }^{\circledR} /$ Rely $X A R C^{\circledR}$. Os núcleos de preenchimento foram feitos em resina composta, sem dentina coronária para efeito férula, e coroas de metal foram cimentadas com ionômero de vidro. Os dentes foram incluídos em resina acrílica com uma camada de elastômero, deixando $2 \mathrm{~mm}$ de raiz exposta acima da superfície de resina. A carga estática foi feita a $3 \mathrm{~mm}$ da borda incisal das coroas, até fratura, num ângulo de $130^{\circ}$ em relação ao seu longo eixo, a uma velocidade de deslocamento de $1 \mathrm{~mm} / \mathrm{min}$. O valor médio do grupo $2(91,20 \mathrm{Kg})$ foi maior do que o do grupo $1(66,95 \mathrm{Kg})$, grupo $3(75,90 \mathrm{Kg})$ e grupo $4(78,91 \mathrm{Kg})(p>0,05)$. As fraturas observadas nos espécimes do grupo 2 e 3 foram do tipo reparáveis, enquanto as dos grupos 1 e 4 foram do tipo não restaurável. Os autores consideram que o módulo de elasticidade dos diferentes pinos intra-radiculares desempenhou um papel preponderante nos resultados, onde os pinos com módulo de elasticidade muito diferente da dentina (grupo 1 e 4) provocaram modos de fratura diferentes dos pinos com módulo de elasticidade mais próximos da dentina.

A grande controvérsia gerada pelos diversos trabalhos na área de núcleos intra-radiculares fez com que HEYDECKE; PETERS ${ }^{52}$ fizessem uma metaanálise, em 2002, dos trabalhos de laboratório e estudos clínicos nesta área. Os autores pesquisaram nas bases de dados MEDLINE e EMBASE para conseguir as publicações em língua inglesa, alemã ou francesa, de 1995 a 2002. Num total, 1773 publicações foram identificadas. Os autores utilizaram os seguintes critérios para 
inclusão das publicações: 1)- para estudos in vitro: dentes unirradiculares, não análogos em resina, restaurados com coroa e ângulo de aplicação da carga de $130^{\circ}$ a $135^{\circ}$; 2)- para estudos in vivo: acompanhamento de 3 ou mais anos, que os dentes anteriores fossem identificados separadamente, restaurados com coroas totais, pilares de PPF, descrição dos sistemas utilizados e informações adequadas quanto à sobrevida ou sucesso dos dentes selecionados. Somente 10 estudos in vitro e 6 estudos in vivo se adequaram a estes critérios. Para os estudos in vitro, a falha sob carga estática foi definida como o resultado primário para fins de comparação.

Os resultados da meta-análise mostraram que a média de resistência à fratura dos dentes restaurados com núcleos metálicos fundidos foi de $571,3 \mathrm{~N}$, e para os dentes restaurados com núcleo de preenchimento e pinos pré-fabricados foi de $601,3 \mathrm{~N}$ nos trabalhos em laboratório. Os autores também avaliaram o modo de fratura e obtiveram uma variação dos tipos desde horizontal profunda a vertical, profunda oblíqua ou somente deslocamento do núcleo intra-radicular, assim como fratura de núcleo de preenchimento, sendo estes últimos somente em dentes restaurados com pinos pré-fabricados e núcleo de preenchimento. Os autores sugerem que existe pouca diferença entre a larga variedade de formas de pinos pré-fabricados e sistemas, quando uma coroa total é usada, e que a resistência à fratura é mais dependente da quantidade de dentina saudável remanescente para permitir o efeito férula pela coroa total.

Quando os autores consideraram os estudos in vivo, a taxa de sucesso para os núcleos metálicos fundidos foi de $87,2 \%$ a $93,0 \%$, num prazo de avaliação de 3 a 6 anos, e a taxa de sucesso dos pinos pré-fabricados e núcleo de preenchimento direto variou de $67,9 \%$ a $92 \%$ num prazo de 3 a 9,5 anos. O sucesso de $67,9 \%$ foi observado em um trabalho onde o autor utilizou uma amostra de 59 pinos préfabricados Dentatus ${ }^{\circledR}$ rosqueáveis cônicos, que registrou 19 falhas. Nesse estudo, o autor enfatizou, no entanto, que o tratamento com estes pinos pré-fabricados foi escolhido para dentes de prognóstico duvidoso, com o intuito de evitar a extração dos mesmos.

Da meta-análise, de maneira geral, os autores concluem que não existem evidências conclusivas em favor tanto de núcleos metálicos fundidos como para sistemas de núcleo de preenchimento e pinos pré-fabricados.

Em 2002, PONTIUS; HUTTER ${ }^{89}$ compararam a taxa de sobrevivência e resistência residual à fratura de incisivos centrais superiores tratados 
endodonticamente e restaurados com 3 tipos de núcleos intra-radiculares, e um grupo sem reforço intra-radicular cobertos com copings de porcelana pura após exposição à carga cíclica. Os autores usaram 40 dentes incisivos centrais superiores tratados endodonticamente e distribuídos aleatoriamente em 4 grupos de 10. As coroas dos dentes dos grupos A, B e C foram removidas $2 \mathrm{~mm}$ acima da junção cemento-esmalte. No grupo $A$, foram usados núcleos metálicos fundidos cimentados com fosfato de zinco. No grupo B, usaram-se pinos intra-radiculares de cerâmica de zircônia, cimentados com sistema Scotchbond Multipurpose ${ }^{\circledR} /$ Panavia $21 \mathrm{TC}^{\circledR}$. Os núcleos de preenchimento foram feitos com capas de cerâmica feldspática Ceracap $\mathrm{F} 1^{\circledR}$, cimentada nos pinos intra-radiculares com Scotchbond Multipurpose ${ }^{\circledR} /$ Herculite $^{\circledR}$. Os núcleos de preenchimento foram usinados até o tamanho dos núcleos de preenchimento dos grupos A e C. No grupo C, os pinos intra-radiculares de resina composta reforçados com cerâmica foram cimentados com Panavia $21 \mathrm{TC}^{\circledR}$, assim como os núcleos de preenchimento de cerâmica Ceracap $F 1^{\circledR}$. No grupo $D$, no qual as coroas não foram removidas, o acesso para tratamento endodôntico foi selado com resina composta Herculite ${ }^{\circledR}$, em combinação com o agente adesivo dentinário, sem nenhum preparo intra-radicular. Copings de Procera All Ceram ${ }^{\circledR}$ foram cimentados com Panavia $21 \mathrm{TC}^{\circledR}$, e os espécimes foram incluídos em resina acrílica, levados em ambiente oral artificial, ficando o limite desta $3 \mathrm{~mm}$ abaixo da junção cemento-esmalte ou do limite cervical dos copings. Os espécimes foram submetidos a uma carga cíclica por 1,2 milhão de ciclos, e os que resistiram ao teste de carga cíclica foram testados à fratura em uma máquina de testes universal, onde uma força foi aplicada com velocidade de $0,5 \mathrm{~mm} / \mathrm{min}, 2 \mathrm{~mm}$ abaixo da borda incisal na face lingual, num ângulo de $135^{\circ}$ em relação ao longo eixo dos dentes.

A taxa de sobrevivência foi de $90 \%$ no grupo $A ; 80 \%$ no grupo $B ; 60 \%$ no grupo $C$ e $100 \%$ no grupo $D$, sendo que neste último grupo, 7 espécimes fraturaram parcialmente ou totalmente durante a carga cíclica. Outra amostra do grupo $C$ não foi à máquina de testes universal, pois tanto o pino intra-radicular quanto o núcleo de preenchimento fraturaram durante o teste de fadiga. Houve diferença na resistência residual $(N)$ entre todos os grupos, exceto entre $A(1270,0 \pm 312,5)$ e $B(1494,7 \pm 333,5)$, A e $C(1146,7 \pm 182,6)$ e entre $B$ e $C$; o grupo $D$ teve o valor de $2362,5 \pm 673,1$. Na análise das fraturas, os espécimes do grupo $A$ (núcleos metálicos fundidos) tiveram fratura vertical, enquanto $C$ e $D$ tiveram fratura ao longo da junção cemento-esmalte. No grupo $B$, houve fratura do coping e núcleo de preenchimento, mas não do pino de cerâmica de zircônia ou da raiz. 
HEYDECKE et $\mathrm{al}^{50}$, em 2002, testaram a resistência à fratura de dentes tratados endodonticamente restaurados com diferentes sistemas de pinos préfabricados e núcleos de preenchimento, depois de submetidos à carga cíclica. Os sistemas testados foram: pinos de zircônia e resina composta, pinos de zircônia e cerâmica vítrea termo-injetada, pinos de titânio e resina composta e núcleos metálicos fundidos em ouro. Para tanto, os pinos foram cimentados em 4 grupos de 10 dentes cada, preparados para coroas totais, deixando 1 a $2 \mathrm{~mm}$ de remanescente dentinário coronário para permitir efeito de férula, cimentados com cimento resinoso, e cobertos com coroa total metálica cimentadas com fosfato de zinco. Os espécimes foram submetidos a 1,2 milhão de ciclos de carga de $30 \mathrm{~N}$, a uma freqüência de $1,3 \mathrm{~Hz}$ em uma máquina de fadiga. Durante o período do teste de carga cíclica, os espécimes foram submetidos simultaneamente à ciclagem térmica variando de $5^{\circ} \mathrm{C}$ a $55^{\circ} \mathrm{C}$ aplicado por 60 s com uma pausa intermediária de 12s. Em seguida, os espécimes foram posicionados em uma máquina de testes universal e carga estática foi aplicada até fratura, incidindo em um ângulo de $130^{\circ} \mathrm{com}$ o longo eixo dos espécimes. As taxas de sobrevivência dos grupos variaram de 93,8\% para os grupos 1 e 2, 100\% para o grupo 3 e 87,5\% para o grupo 4 . A média de resistência à fratura foi de $450 \mathrm{~N}, 503 \mathrm{~N}$, $521 \mathrm{~N}$ e $408 \mathrm{~N}$ respectivamente. Nenhuma diferença foi detectada entre os grupos. $\mathrm{O}$ uso de pinos de cerâmica de zircônia não resultou em significante aumento do número de fraturas catastróficas de raízes. Os autores sugerem que os pinos de cerâmica de zircônia com núcleos de preenchimento de cerâmica termo-injetada podem ser recomendados como uma alternativa segura aos núcleos metálicos fundidos. Ainda mais, se um procedimento em uma única sessão é o preferido, que a associação entre os pinos de cerâmica de zircônia e resina composta pode ser empregada, desde que sejam observadas as condições do remanescente dental especificadas pelo trabalho.

FERNANDES; SHETTY; COUTINHO ${ }^{32}$, em 2003, ao realizarem uma revisão de literatura de 1961 a 2002, verificaram os vários fatores que influenciam na seleção do pino intra-radicular para restaurar dentes tratados endodonticamente. Os seguintes fatores foram listados: 1- Tamanho da raiz; 2- Anatomia da raiz; 3- Largura do pino - quanto mais dentina for deixada em detrimento da largura do pino, mais resistente será o dente restaurado; 4- Configuração do canal e adaptabilidade do pino, que é um fator relevante na decisão entre pinos pré-fabricados e núcleos metálicos fundidos. Se o pino intra-radicular selecionado se adapta intimamente ou se conforma à forma e tamanho do canal, esta pode ser a opção mais conservadora, pois menos remoção de dentina é requerida, assim aumentando a resistência do dente à fratura, como também a retenção do pino intra-radicular. No entanto, o dilema aparece em 
canais em forma de funil, onde se deve optar pelo uso de pinos pré-fabricados de paredes paralelas e preenchimento de espaço remanescente do pino com cimento ou usar pino pré-fabricado cônico que se adapta intimamente à parede do canal. Uma terceira opção, de acordo com os autores, seria a de usar pinos pré-fabricados grandes, pela remoção de estrutura dental adicional, para que se consiga um íntimo contato entre o pino pré-fabricado e o canal. É também sugerido que se um canal requer preparo extenso, um núcleo metálico fundido será mais retentivo do que um pino pré-fabricado que não se adapta à forma do canal. Ainda mais, sugere-se que um reforço radicular com compósito pode ser indicado para canais extremamente alargados antes da instalação do núcleo metálico fundido; 5 - Estrutura coronária uma estrutura coronária de 1,5 a 2,0 $\mathrm{mm}$ acima da linha de término marginal permite que seja atingida uma forma de resistência para o remanescente dental restaurado com coroa total, permitindo o uso de pino pré-fabricado de resina composta reforçado por fibra. A ausência deste remanescente sugere o uso de núcleo metálico fundido; 6 - Papel da pressão hidrostática - os cimentos resinosos têm sido usados em detrimento ao cimento de fosfato de zinco, sendo os de polimerização dupla lenta os mais indicados; 7 - Forma e desenho do pino pré-fabricado - os pinos pré-fabricados de paredes paralelas aumentam a retenção e produzem distribuição do estresse ao longo do seu comprimento. No entanto, é esperado que uma concentração de estresse ocorra no ápice do pino, principalmente em ápices de raízes cônicas ou estreitadas. O desenho dos pinos de paredes paralelas e extremidade cônica permite preservação da porção mais apical, que é cônica. Este desenho permite a preservação de dentina no ápice e, ao mesmo tempo, atinge retenção suficiente por causa do desenho paralelo; 8- Material do pino pré-fabricado - para atingir ótimos resultados, o material usado para o pino pré-fabricado deveria ter propriedades físicas similares àquelas da dentina, ser aderido à estrutura dental e biocompatível com o meio ambiente oral. Os pinos pré-fabricados mais rígidos, tais como os metálicos, resistem a forças maiores sem distorção, mas podem suscitar um perigo potencial de fraturas. É relatado que os pinos intra-radiculares de resina composta reforçados por fibra têm propriedades mecânicas que se aproximam às dos dentes. Por outro lado, é assumido que os pinos pré-fabricados de cerâmica de zircônia têm um alto módulo de elasticidade, e que as forças são transmitidas diretamente do pino pré-fabricado para a interface do dente sem absorção de choque. Os pinos pré-fabricados de cerâmica, mais rígidos, podem causar mais fraturas dos remanescentes dentais, comparados com pinos intra-radiculares de resina composta reforçados por fibra; 9 Compatibilidade do material - das várias ligas metálicas utilizadas para pinos préfabricados, as de titânio são as mais resistentes à corrosão. Com a disponibilidade dos 
materiais de pinos não metálicos, o fator corrosão foi eliminado; 10 - Propriedade de adesão - a adesão do pino à estrutura dental aumenta o bom prognóstico dos dentes tratados endodonticamente pelo reforço da estrutura dental. Tem sido postulado que o reforço do dente deve-se à distribuição do estresse dos materiais adesivos. Recentemente, tem sido relatado que a adesão de materiais resinosos a pinos préfabricados de resina composta é muito melhor do que aos de cerâmica de zircônia; 10 - Estética, e 11 - Facilidade de remoção - a remoção de pinos pré-fabricados sem perda de tecido dentário seria ideal. Os pinos intra-radiculares de resina composta reforçados por fibra são preferíveis aos pinos metálicos e de cerâmica de zircônia.

QUALTROUGH; MANNOCCI ${ }^{90}$, em 2003, revisaram as perspectivas atuais dos pinos pré-fabricados estéticos. Citaram as vantagens dos pinos de cerâmica de zircônia: boa estética e propriedades mecânicas, aliadas ao seu comportamento biológico inerte, e como desvantagens o fato de serem difíceis de remover, alto módulo de elasticidade e que podem agir desfavoravelmente na raiz, levando a sua fratura ao invés de simplesmente se descimentar. Pinos intraradiculares de resina composta reforçados por fibra de carbono são escuros,o que determinou a substituição do carbono por fibras de vidro ou quartzo. Esse fato tornou estes pinos esteticamente agradáveis, somando-se a isso sua boa resistência mecânica, bom comportamento estético e biológico. Além disso, seu módulo de elasticidade, similar ao da dentina (18 a $21 \mathrm{GPa}$ ), resistência à corrosão, fácil remoção dos canais, boa resistência adesiva à resina composta, quando usado com as técnicas de cimentação adesiva intra-radicular. Supõe-se que quando dentes restaurados com estes pinos são submetidos a estresse, ocorre descimentação dos pinos ao invés de fratura radicular.

Os autores sugerem que ao invés de se ressaltar as vantagens adicionais dos sistemas de núcleos intra-radiculares estéticos mais novos deve-se evidenciar que, estudos de longo prazo, para fornecer boas evidências clínicas, ainda são escassos ou inexistentes, mas absolutamente essenciais para se julgar o desempenho clínico destes materiais. 
3 PROPOSIC̣ÃO 


\section{PROPOSIÇÃO}

Este estudo se propõe testar as seguintes hipóteses:

1- A carga cíclica diminui a resistência de dentes tratados endodonticamente reconstruídos com núcleos estéticos e metálicos e restaurados com coroas de porcelana pura.

2- Dentes tratados endodonticamente reconstruídos com pinos pré-fabricados estéticos apresentam valores maiores do que aqueles restaurados com pinos pré-fabricados metálicos, todos restaurados com coroas de porcelana pura, quanto a:

a- Taxa de sobrevivência quando submetidos à carga cíclica em teste não destrutivo.

b- Resistência à fratura sob carga estática com e sem efeito de carga cíclica.

c- Modo de fratura radicular favorável à recuperação do remanescente dental após aplicação de carga estática até a falha, com e sem efeito de carga cíclica.

3- Há relação entre as dimensões MD e VL com a carga estática necessária à fatura, de dentes tratados endodonticamente reconstruídos com sistemas de pinos pré-fabricados metálicos e estéticos, restaurados com coroas de porcelana pura. 
4 MATERIAL e MÉTODOS 


\section{MATERIAL e MÉTODOS}

\subsection{Seleção da Amostra}

Foram selecionados sessenta caninos superiores, obtidos de pacientes da Universidade Federal do Espírito Santo, na disciplina de Cirurgia Oral. Os pacientes foram esclarecidos quanto ao uso dos dentes para esta pesquisa, e assinaram o termo de consentimento de doação dos mesmos, seguindo o protocolo do conselho de ética sob o $\mathrm{n}^{\circ}$ 116/2002. Os dentes foram conservados em solução de Timol $0,1 \%$ por no máximo 6 meses. Durante todo o trabalho os dentes foram mantidos em água destilada nos intervalos dos procedimentos e envoltos em gases úmidas durante os mesmos. Foram analisados quanto à presença de cáries ou trincas por inspeção visual e análise no microscópio ótico, com um aumento de 20X, tendo sido admitida à presença de pequenas cáries nas faces proximais localizadas acima da junção cemento-esmalte. As coroas foram amputadas a $1,5 \mathrm{~mm}$ acima da junção cemento-esmalte, com disco de diamante em um cortador de dentes, utilizando uma velocidade de $300 \mathrm{rpm}$ e uma força de $800 \mathrm{~g}$ sob refrigeração com água. Os desgastes dentários foram realizados com brocas diamantadas, de forma cilíndrica com extremos arredondados. Os dentes foram preparados para receber coroas de porcelana pura deixando término com espessura de $1,0 \mathrm{~mm}$ nas faces vestibular e lingual, e $0,8 \mathrm{~mm}$ nas faces proximais. A altura das paredes axiais foi estabelecida em 1,5mm, determinando o término do preparo ao nível da junção cemento-esmalte. Em seguida, foram registradas suas medidas $M D$ e VL com um paquímetro digital. Foram admitidas dimensões MD variando de 4,60 a 6,37mm e 6,39 a 7,99mm para o sentido VL.

Os intervalos entre as extensões máximas e mínimas de cada face (VL e MD) foram divididos em 3 grupos iguais e denominados de Pequeno (P), Médio (M) e Grande $(G)$, sendo que no sentido $V L$ as medidas $P$ ficaram entre 6,39 e 6,93mm, as $M$ entre 6,94 e $7,48 \mathrm{~mm}$ e as $G$ entre 7,49 e $7,99 \mathrm{~mm}$. No sentido $M D$, as medidas $P$ estavam entre 4,60 e 5,14mm, as $M$ entre 5,15 e 5,69mm e as $G$ entre 5,70 e 6,37mm. Assim, os dentes foram classificados de acordo com a combinação das medidas (VL/MD), resultando em dentes G/G, G/M, G/P, M/M, M/P e P/P. Utilizando o sistema de distribuição estratificada, os dentes foram distribuídos em 6 grupos de 10 dentes, de acordo com estas medidas, e são citados na Tabela 4.1. 
Tabela 4.1 - Distribuição dos dentes $\left(n^{\circ}\right)$ e suas dimensões $(\mathrm{mm})$ MD e VL.

\begin{tabular}{|c|c|c|c|c|c|c|c|c|c|c|c|c|c|c|c|c|c|}
\hline \multicolumn{3}{|c|}{ Grupo 1} & \multicolumn{3}{|c|}{ Grupo 2} & \multicolumn{3}{|c|}{ Grupo 3} & \multicolumn{3}{|c|}{ Grupo 4} & \multicolumn{3}{|c|}{ Grupo 5} & \multicolumn{3}{|c|}{ Grupo 6} \\
\hline \multicolumn{3}{|c|}{ Dimensões } & \multicolumn{3}{|c|}{ Dimensões } & \multicolumn{3}{|c|}{ Dimensões } & \multicolumn{3}{|c|}{ Dimensões } & \multicolumn{3}{|c|}{ Dimensões } & \multicolumn{3}{|c|}{ Dimensões } \\
\hline $\mathrm{N}^{\circ}$ & VL & MD & $\mathrm{N}^{\circ}$ & VL & MD & $\mathrm{N}^{\circ}$ & $\mathrm{VL}$ & MD & $\mathrm{N}^{\circ}$ & $\overline{V L}$ & MD & $\mathrm{N}^{\circ}$ & $\mathrm{VL}$ & MD & $\mathrm{N}^{\circ}$ & $\mathrm{VL}$ & MD \\
\hline 10 & 7,99 & 5,75 & 08 & 7,32 & 5,22 & 07 & 7,95 & 6,00 & 03 & 7,11 & 4,95 & 02 & 7,14 & 5,45 & 01 & 7,39 & 5,01 \\
\hline 17 & 7,85 & 5,76 & 09 & 7,91 & 6,13 & 11 & 7,08 & 5,22 & 05 & 7,74 & 5,40 & 12 & 7,86 & 5,94 & 04 & 7,67 & 4,83 \\
\hline 21 & 7,95 & 5,95 & 14 & 7,12 & 5,36 & 19 & 7,88 & 5,37 & 06 & 7,31 & 5,12 & 15 & 7,96 & 5,50 & 13 & 7,85 & 5,41 \\
\hline 30 & 7,48 & 5,14 & 23 & 7,60 & 4,93 & 26 & 7,97 & 5,07 & 18 & 7,96 & 5,15 & 22 & 7,62 & 5,06 & 16 & 7,95 & 5,05 \\
\hline 35 & 7,99 & 5,21 & 32 & 7,85 & 5,76 & 29 & 7,80 & 5,64 & 25 & 7,95 & 5,74 & 24 & 7,74 & 5,30 & 20 & 7,61 & 5,63 \\
\hline 36 & 7,26 & 4,60 & 34 & 7,56 & 5,01 & 33 & 7,99 & 5,20 & 27 & 7,95 & 5,54 & 37 & 7,99 & 5,46 & 28 & 7,10 & 5,19 \\
\hline 41 & 7,61 & 5,64 & 39 & 7,15 & 5,40 & 38 & 7,95 & 5,55 & 31 & 7,85 & 4,63 & 44 & 7,91 & 6,07 & 45 & 7,97 & 5,58 \\
\hline 46 & 7,99 & 5,38 & 43 & 7,36 & 5,55 & 42 & 7,03 & 5,30 & 40 & 7,85 & 4,91 & 48 & 7,59 & 4,87 & 47 & 7,83 & 6,00 \\
\hline 49 & 7,49 & 5,40 & 53 & 7,98 & 5,10 & 52 & 7,67 & 4,90 & 56 & 7,97 & 5,54 & 58 & 7,91 & 5,52 & 50 & 7,25 & 4,98 \\
\hline 55 & 7,96 & 5,95 & 60 & 7,99 & 5,64 & 54 & 7,93 & 5,98 & 57 & 7,98 & 5,41 & 59 & 7,84 & 5,36 & 51 & 7,97 & 5,70 \\
\hline
\end{tabular}

Os dados da estatística descritiva dos valores das dimensões VL e MD estão descritos nas Tabelas 4.2 e 4.3 no Anexo 1. Esses dados foram submetidos ao teste estatístico de Levene para confirmar a homegeneidade entre os grupos $(p<0,05)$, expressos nas Tabela 4.4 (Anexo 2). O teste de ANOVA a 1 critério $(p<0,05)$ foi usado e confirmou a homogeneidade entre os valores das dimensões MD e VL de todos os grupos (Tabelas 4.5 e 4.6 - Anexo 2).

\section{2 - Preparo dos Canais Radiculares}

Utilizando uma broca diamantada esférica, foi completado o acesso aos canais radiculares de todos os dentes e, em seguida, usadas limas para instrumentar os canais até o no 40 . Foi usado hipoclorito de sódio a $2,5 \%$ para irrigação e limpeza dos canais os quais foram secos com cones de papel absorventes. Os condutos foram obturados com guta percha e cimento de hidróxido de cálcio pela técnica de condensação lateral, usando os condensadores laterais $n^{\circ} 30$ e 35 . Os excessos dos 
cones foram cortados e removidos com instrumento aquecido. Procedeu-se, então à obturação dos canais e os dentes foram recolocados em água destilada.

Em seguida, os condutos de todos os remanescentes dentários foram preparados para os pinos intra-radiculares com as brocas dos respectivos sistemas. Os espaços para os pinos intra-radiculares foram programados para terem $10,5 \mathrm{~mm}$ de comprimento e os pinos intra-radiculares $15 \mathrm{~mm}$, sendo a extensão coronária dos núcleos de preenchimento de 4,5mm de comprimento.

\section{3 - Constituição dos Grupos}

Os grupos foram constituídos de acordo com o material utilizado e tratamentos a que foram submetidos, e estão dispostos na Tabela 4.7.

Tabela 4.7. Constituição dos grupos de acordo com os sistemas de núcleos intraradiculares, materiais e tratamentos usados.

\begin{tabular}{c|c|c|c|c}
\hline \hline Grupos & Pino Pré-fabricado & $\begin{array}{c}\text { Material do Núcleo de } \\
\text { Preenchimento }\end{array}$ & $\begin{array}{c}\text { Ciclagem } \\
\text { Térmica(no de } \\
\text { ciclos) }\end{array}$ & $\begin{array}{c}\text { Ciclagem } \\
\text { Mecânica(no } \\
\text { de ciclos) }\end{array}$ \\
\hline $\mathbf{1}$ & Cerâmica de zircônia & Cerâmica vítrea & $300 \mathrm{X}$ & 0 \\
\hline $\mathbf{2}$ & Cerâmica de zircônia & Cerâmica vítrea & $300 \mathrm{X}$ & 500,000 \\
\hline $\mathbf{3}$ & $\begin{array}{c}\text { Resina composta } \\
\text { reforçada com fibra } \\
\text { de vidro }\end{array}$ & $\begin{array}{c}\text { Resina composta } \\
\text { reforçada com fibra de } \\
\text { vidro }\end{array}$ & $300 \mathrm{X}$ & 0 \\
\hline $\mathbf{4}$ & $\begin{array}{c}\text { Resina composta } \\
\text { reforçada com fibra } \\
\text { de vidro }\end{array}$ & $\begin{array}{c}\text { Resina composta } \\
\text { reforçada com fibra de } \\
\text { vidro }\end{array}$ & $300 \mathrm{X}$ & 500,000 \\
\hline $\mathbf{5}$ & Liga de titânio & $\begin{array}{c}\text { Resina composta } \\
\text { reforçada com fibra de } \\
\text { vidro }\end{array}$ & $300 \mathrm{X}$ & 0 \\
\hline $\mathbf{6}$ & Liga de titânio & $\begin{array}{c}\text { Resina composta } \\
\text { reforçada com fibra de } \\
\text { vidro }\end{array}$ & $300 \mathrm{X}$ & 500,000 \\
\hline \hline
\end{tabular}

Os sistemas de pinos pré-fabricados intra-radiculares e as respectivas brocas utilizados para a confecção dos espécimes são mostrados na figura 4.1. 


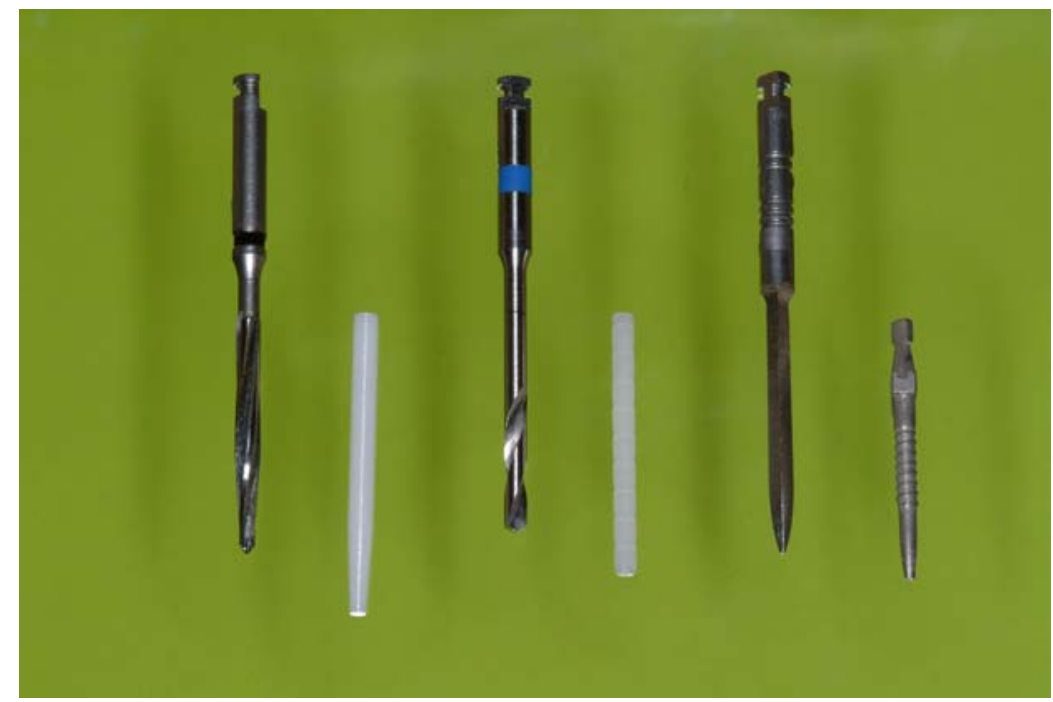

Figura 4.1. Sistemas de pinos e respectivas brocas utilizados: (A)Zircônia, (B)Resina composta reforçada por fibra de vidro e (C)Titânio.

\subsection{Preparo dos núcleos intra-radiculares dos grupos 1 e 2}

\subsubsection{Obtenção dos modelos e ceroplastia}

Os grupos 1 e 2 receberam pinos pré-fabricados de cerâmica de zircônia de $1,7 \mathrm{~mm}$ de diâmetro e 20,5mm de comprimento, de forma cilíndrica, com extremidade cônica.

Após o preparo inicial com as brocas de Peeso, os canais foram preparados utilizando as brocas fornecidas pelo fabricante. Sendo a técnica de confecção pelo método indireto, os canais dos 20 remanescentes dentais foram moldados utilizando-se pinos metálicos fornecidos pelo fabricante e as massas densa e fluida da silicona de adição, por meio da técnica de dupla mistura. Após $1 \mathrm{~h}$, os moldes foram vazados com gesso especial na proporção $22 \mathrm{ml} / 100 \mathrm{~g}$, espatulados a 350 rpm em um misturador mecânico a vácuo e deixados cristalizar por $2 \mathrm{~h}$. Os modelos foram tratados com um líquido endurecedor de gesso e isolados com isolante próprio. Os pinos de zircônia foram posicionados nos modelos e usou-se cera para confeccionar a parte coronária dos núcleos intra-radiculares, com 4,5mm de comprimento e face lingual oblíqua, com inclinação de $45^{\circ}$. 


\subsubsection{Inclusão e termo-injeção da porcelana vítrea}

Os conjuntos pinos/padrões de cera foram removidos dos modelos e preparados para inclusão, de acordo com as instruções do fabricante, em anel de papel especial. O revestimento foi usado segundo as instruçõess do fabricante, na proporção $22 \mathrm{ml} / 100 \mathrm{~g}$, sendo $11 \mathrm{ml}$ de líquido de revestimento e $11 \mathrm{ml}$ de água destilada e manipulado manualmente por 20s com cubeta de borracha e espátula metálica e, em seguida, no misturador mecânico a vácuo. O revestimento foi vazado no anel e deixado cristalizar por 45min. Os anéis de termo-injeção foram levados ao forno de fundição para evaporação da cera. O programa seguido está descrito no Anexo 3 (Tabela 4.8).

Após a evaporação da cera, os lingotes de porcelana frios foram inseridos nos anéis de termo-injeção, os quais eram posicionados imediatamente no forno de termo-injeçao de porcelana, acionando-se o programa $n^{\circ} 13$, como descrito na tabela 4.9, no Anexo 3.

\subsubsection{Desinclusão dos núcleos intra-radiculares cerâmicos e ajuste nos modelos}

Após o processo de termo-injeção, os anéis foram deixados resfriar sobre a bancada e, em seguida, desincluídos com jato de micro-esferas de $50 \mu \mathrm{m}$ a uma pressão de 2,8Bars até completar a limpeza (Figura 4.2 ).

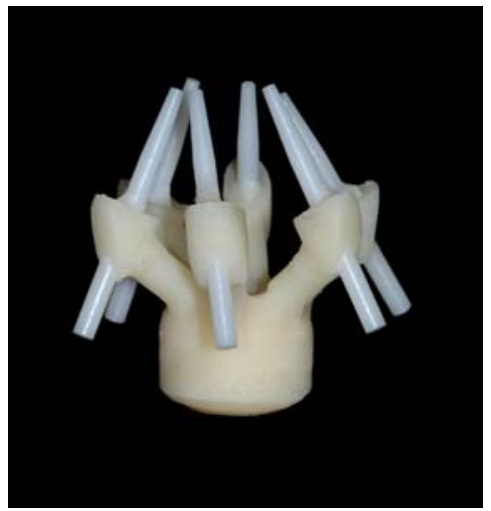

Figura 4.2. Pinos de zircônia após a termo-injeção da porcelana vítrea.

Para a separação dos núcleos de cerâmica de zircônia do botão de termo-injeção, a peça termo-injetada foi mantida umedecida e, então, usado um disco de dupla face diamantada em baixa rotação. A adaptação dos núcleos nos respectivos 
modelos de gesso foi feita com auxílio de líquido evidenciador e, se necessário, ajustes eram feitos com uma broca diamantada esférica sob irrigação abundante. Uma vez adaptados, os núcleos intra-radiculares de zircônia foram lavados com sabão neutro e imersos em álcool isopropílico no aparelho de ultra-som, por $15 \mathrm{~min}$, para limpeza e, em seguida, secados com jatos de ar comprimido.

\subsection{Cimentação dos núcleos intra-radiculares cerâmicos e pinos intra-radiculares de resina composta reforçados com fibra de vidro e titânio}

Para cimentação dos núcleos intra-radiculares cerâmicos nos remanescentes radiculares, a parte de cerâmica vítrea em contato com o remanescente dental dos núcleos foi tratada com ácido hidrofluorídrico a $5 \%$ por $1 \mathrm{~min}$, de acordo com o fabricante, lavados com água e secados com jatos de ar comprimido. Em seguida, aplicado silano somente na região atacada por ácido e, após $1 \mathrm{~min}$, secados com jatos ar comprimido. O agente de adesão dentinária foi misturado, manipulado por 10s em um casulo plástico próprio e aplicado somente na parte interna que recebeu tratamento com ácido hidrofluorídrico dos núcleos com um pincel fornecido pelo fabricante.

Para os grupos 3 e 4, foram utilizados os pinos pré-fabricados de resina composta reforçados por fibra de vidro de $1,5 \mathrm{~mm}$ de diâmetro e $18 \mathrm{~mm}$ de comprimento, com formato cilíndrico e retenções mecânicas ao longo de toda a extensão (Figura 4.1). Para os grupos 5 e 6, foram utilizados os pinos pré-fabricados de titânio de 1,65mm de diâmetro e $18 \mathrm{~mm}$ de comprimento, com formato cilíndricocônico, com retenções no terço médio (Figura 4.1). Para os dois tipos de pinos foi aplicado ácido fosfórico a $37 \%$ por 20 s e, em seguida, lavados com água e secados com jatos de ar comprimido. Nos dois tipos de pinos foi aplicado o agente de adesão dentinária, o qual foi previamente misturado e manipulado por 10 s no casulo plástico próprio.

O restante dos procedimentos do processo de cimentação foi o mesmo para os 6 grupos: os canais dos remanescentes dentais foram lavados com água, secados com jatos de ar comprimido e cones de papel até garantir absoluta secagem. Em seguida, foi aplicado ácido fosfórico a $37 \%$ por 15 s, lavados com água e secados com cones de papel absorvente, permitindo à dentina ficar levemente úmida para aplicação do agente de adesão dentinária de acordo com as instruções do fabricante. Em seguida, foi feita aplicação do agente de adesão dentinária, o qual foi misturado, 
manipulado por 10s no casulo plástico próprio e aplicado no remanescente dentário com pincel fornecido pelo fabricante. Para cimentação dos pinos pré-fabricados, foi utilizado um cimento de polimerização dupla, dosado e manipulado em bloco de papel com espátula de plástico própria. Para sua inserção nos condutos dos remanescentes dentários para os pinos, foi usada broca de Lentulo em baixa rotação. O cimento foi também pincelado nos pinos pré-fabricados os quais em seguida, foram inseridos nos canais. Após $2 \mathrm{~min}$, o excesso foi removido com sonda exploradora $\mathrm{n}^{\circ} 5$. Foram esperados $5 \mathrm{~min}$ para polimerização final, e somente os espécimes do grupo 1 e 2 foram armazenados em água em seguida.

\subsection{Confecção dos núcleos de preenchimento em resina composta}

Nos grupos 3, 4, 5 e 6, utilizando um pincel fornecido pelo fabricante, foi aplicado novamente o agente de adesão dentinária nos pinos, dentina e cimento, previamente misturado, manipulado por 10s no casulo plástico próprio. Em seguida, uma resina reforçada com fibras de vidro de polimerização dupla foi dosada em bloco de papel, manipulada com espátula de plástico própria e inserida em formas plásticas para em seguida, serem posicionadas na porção coronária dos remanescentes. Após o tempo de polimerização de $4 \mathrm{~min}$, as formas plásticas foram removidas e os espécimes recolocados em água destilada.

\subsection{Repreparo e moldagem dos dentes}

Para iniciar o repreparo houve uma espera de 24 horas após a confecção dos núcleos de preenchimento. A porção coronária dos espécimes foi repreparada com brocas diamantadas, com forma cilíndrica, e extremos arredondados, para receber coroas de porcelana pura. Os preparos apresentaram término com espessura de $1,0 \mathrm{~mm}$ nas faces vestibular e lingual, e $0,8 \mathrm{~mm}$ nas faces proximais. A altura do preparo foi de $6 \mathrm{~mm}$, e a superfície lingual foi confeccionada com inclinação de $45^{\circ}$ em relação ao longo eixo dos dentes (Figura 4.3). Para dar acabamento nos preparos, foram usadas brocas multilaminadas carbide em baixa rotação. 

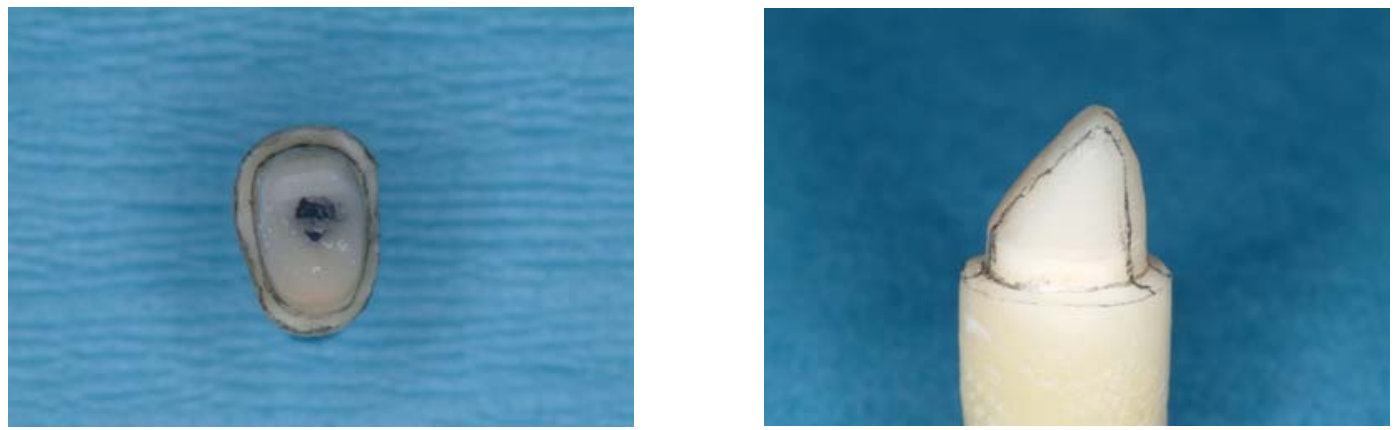

Figura 4.3. Preparo concluído: vistas incisal e lateral.

Os preparos foram moldados com silicona usando a técnica da dupla mistura e, após $1 \mathrm{~h}$ vazado gesso especial, proporcionado na relação $22 \mathrm{ml} / 100 \mathrm{~g}$ e espatulado a vácuo. Após $2 \mathrm{~h}$, os modelos foram removidos dos moldes e tratados com agente endurecedor e isolados.

\subsection{Confecção das coroas de porcelana pura}

A ceroplastia das coroas foi feita com cera sobre os troquéis de gesso, nas seguintes dimensões: altura de $8,0 \mathrm{~mm}$, espessura do bordo incisal de $2,0 \mathrm{~mm}$, espessura de bordos cervicais de $0,8 \mathrm{~mm}$ nas faces proximais e $1,0 \mathrm{~mm}$ nas faces vestibular e lingual. A altura da parede lingual foi de $2,5 \mathrm{~mm}$ e a superfície lingual foi confeccionada, plana com inclinação de $45^{\circ}$, para alojar a esfera metálica durante 0 teste com carga cíclica e o cilindro para o teste com carga estática.

Os padrões de cera foram incluídos com revestimento especial, dosado na proporção $100 \mathrm{~g} / 22 \mathrm{ml}$, sendo $13 \mathrm{ml}$ de líquido de revestimento e $9 \mathrm{ml}$ de água. $\mathrm{O}$ revestimento foi manipulado manualmente por $20 \mathrm{~s}$, em cubeta de borracha com espátula metálica e, depois, no misturador mecânico a vácuo. Em seguida, o revestimento foi vazado em anel de papel fornecido pelo fabricante e deixado cristalizar por 45min. Os anéis foram, então, levados ao forno de fundição para evaporação da cera, seguindo o programa descrito na Tabela 4.8 (Anexo 3).

Os lingotes de porcelana foram submetidos ao mesmo processo de aquecimento que os anéis de termo-injeção. Ao término do programa do forno de evaporação da cera, os lingotes de porcelana foram inseridos nos anéis, os quais foram posicionados no forno de termo-injeção de porcelana. O programa no 11 do 
forno de porcelana, acionado para a termo-injeção de porcelana, está descrito na Tabela 4.10 (Anexo 4).

Após o processo de termo-injeção, os anéis foram deixados resfriar sobre a bancada e desincluídos utilizando jateamento com micro-esferas de $50 \mu \mathrm{m}$, a uma pressão de 2,8Bars até completa limpeza. Em seguida, os espécimes foram separados do botão de termo-injeção com auxílio de um disco diamantado e adaptados nos respectivos modelos. Para tanto, foi usado líquido evidenciador que foi pincelado sobre os troquéis, marcando os contatos na superfície interna das coroas que impediam seu assentamento completo nos troquéis.

Esses contatos foram desgastados com broca diamantada esférica em alta rotação sob refrigeração com água. Uma vez adaptadas nos respectivos troquéis, as coroas foram assentadas nos preparos e a adapatação conferida com a sonda exploradora no 5 e sob aumento de $20 X$ no microscópio ótico. A adaptação foi considerada adequada quando não era mais detectado nenhum tipo de degrau à sondagem no término da coroa. Se necessário, o interior das coroas era pincelado com o líquido evidenciador para melhorar a adaptação das mesmas. Em seguida, as coroas foram polidas com borrachas diamantadas, lavadas com água e sabão, levadas ao aparelho de ultra-som para limpeza em álcool isopropílico, por 15min, e secadas com jato de ar comprimido. A massa para glaze foi usada a fim de glazear as coroas, utilizando um forno para cerâmica conforme o programa descrito na Tabela 4.11 (Anexo 4). Após o processo de glazeamento, a adaptação das coroas foi novamente aferida.

\subsection{Cimentação das coroas}

As coroas tiveram suas superfícies internas tratadas com ácido hidrofluorídrico a $5 \%$, por 20 s, de acordo com as instruções do fabricante, lavados com água e secados com jatos de ar comprimido. Em seguida, foi aplicado o silano, deixado secar por $1 \mathrm{~min}$ e removido o excesso com jatos de ar comprimido. $\mathrm{O}$ agente de adesão dentinária foi misturado por $10 \mathrm{~s}$, em um casulo plástico próprio, e aplicado no interior da coroa com um pincel fornecido pelo fabricante. Para a cimentação das coroas, foi utilizado o cimento resinoso de polimerização dupla, o qual foi dosado e manipulado em bloco de papel com espátula de plástico própria. O cimento foi pincelado nas superfícies internas das coroas, que foram posicionadas nos preparos e mantidas em posição com força digital. Em seguida, os espécimes foram posicionados em um dispositivo para manter as coroas sob pressão de $5 \mathrm{~kg}$ por $5 \mathrm{~min}$. Finalizando, 
os excessos de cimento foram removidos com uma lâmina de bisturi $n^{\circ} 15$, e os espécimes foram armazenados novamente em água destilada.

\subsection{Teste de termociclagem}

Para a termociclagem foram esperadas vinte e quatro horas após a cimentação. Os espécimes foram levados a uma máquina de termocliclagem (Laboratório de Materiais Restauradores e Biomateriais da Escola de Odontologia da Universidade de Boston), onde foram submetidos a 300 ciclos, com variação de temperatura de $5^{\circ} \mathrm{C}$ a $55^{\circ} \mathrm{C}$, com tempo de espera de 30 s em cada banho, e intervalo entre os dois tanques de $30 \mathrm{~s}$. As temperaturas foram controladas com termômetros digitais garantindo uma variação de temperatura de no máximo $\pm 0,5^{\circ} \mathrm{C}$.

\subsection{Teste de carga cíclica}

Para a realização do teste de carga cíclica, os espécimes foram montados em bases obtidas a partir de barras de alumínio, com $5 \mathrm{~cm}$ de comprimento e $2 \mathrm{~cm}$ altura, com as extremidades inclinadas em $45^{\circ}$. Nos dois extremos das bases foram feitas perfurações, com diâmetro de $10 \mathrm{~mm}$, suficientes para alojar os espécimes com seus longos eixos inclinados em $45^{\circ}$ em relação ao plano horizontal. Nos espécimes foram feitas marcas com grafite a $2 \mathrm{~mm}$ abaixo do limite das margens cervicais das coroas, simulando o limite da crista óssea e, em seguida, foram posicionados com os longos eixos paralelos às paredes das perfurações das barras de alumínio e mantidos em posição com cera utilidade. Resina acrílica foi manipulada e vertida nas perfurações com auxílio de espátula 7 , cobrindo as raízes até a marca indicativa do nível da crista óssea. Em seguida, os conjuntos foram colocados em água até completa polimerização da resina. Após $10 \mathrm{~min}$, procedeu-se à remoção dos excessos de resina acrílica (Figura 4.4).

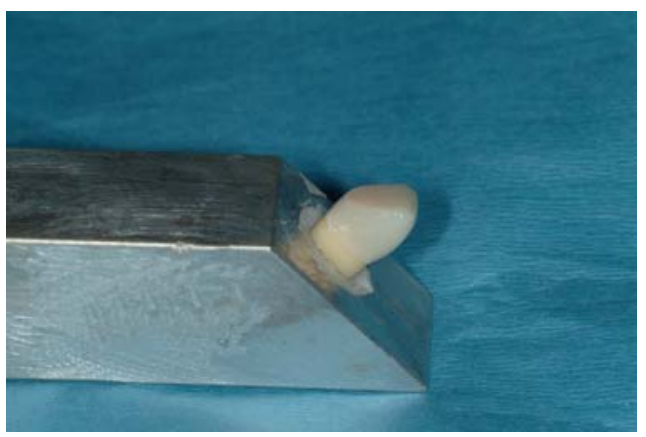

Figura 4.4. Espécime montado na base metálica para o ensaio de fadiga. 
Dos 60 espécimes do trabalho, 30 foram destinados ao teste de carga cíclica (grupos 2, 4 e 6), agora chamados "grupos-experimentais". Os outros espécimes (grupos 1, 3 e 5) foram denominados "grupos-controles".

$\mathrm{Na}$ base dos espécimes dos grupos-experimentais, foi colada uma caixa acrílica com cianoacrilato funcionando como recipiente de água destilada para manter os espécimes sempre hidratados durante o teste de carga cíclica. Em seguida, foram feitas duas perfurações de $1,5 \mathrm{~mm}$ de diâmetro nas superfícies superiores das bases metálicas, onde foram posicionados dois pinos de aço inoxidável, distantes $20 \mathrm{~mm}$ entre si. Sobre os pinos foi acoplada uma barra de aço não inoxidável, de $0,8 \mathrm{~mm}$ de altura, 0,8mm de largura e $45 \mathrm{~mm}$ de comprimento, com duas perfurações distantes $20 \mathrm{~mm}$ entre si. Numa das extremidades dessa barra foi inserida uma esfera metálica em um casulo que permitia um movimento de rotação da mesma. O encaixe das barras aos pinos de aço inoxidável permitiu sua movimentação no sentido vertical, proporcionando contato da esfera a $3 \mathrm{~mm}$ da face incisal da coroa de porcelana. Figura 4.5 .

Os 30 espécimes dos grupos-experimentais foram posicionados na máquina de fadiga regulada a uma freqüência de $1,7 \mathrm{~Hz}$ e submetidos a 500.000 ciclos de carga com pico máximo de $250 \mathrm{~N}$. O contato entre a esfera metálica e as coroas de porcelana dos espécimes foi aferido com fita de marcar contatos oclusais, a cada 50.000 ciclos, e calibrados quando necessário.
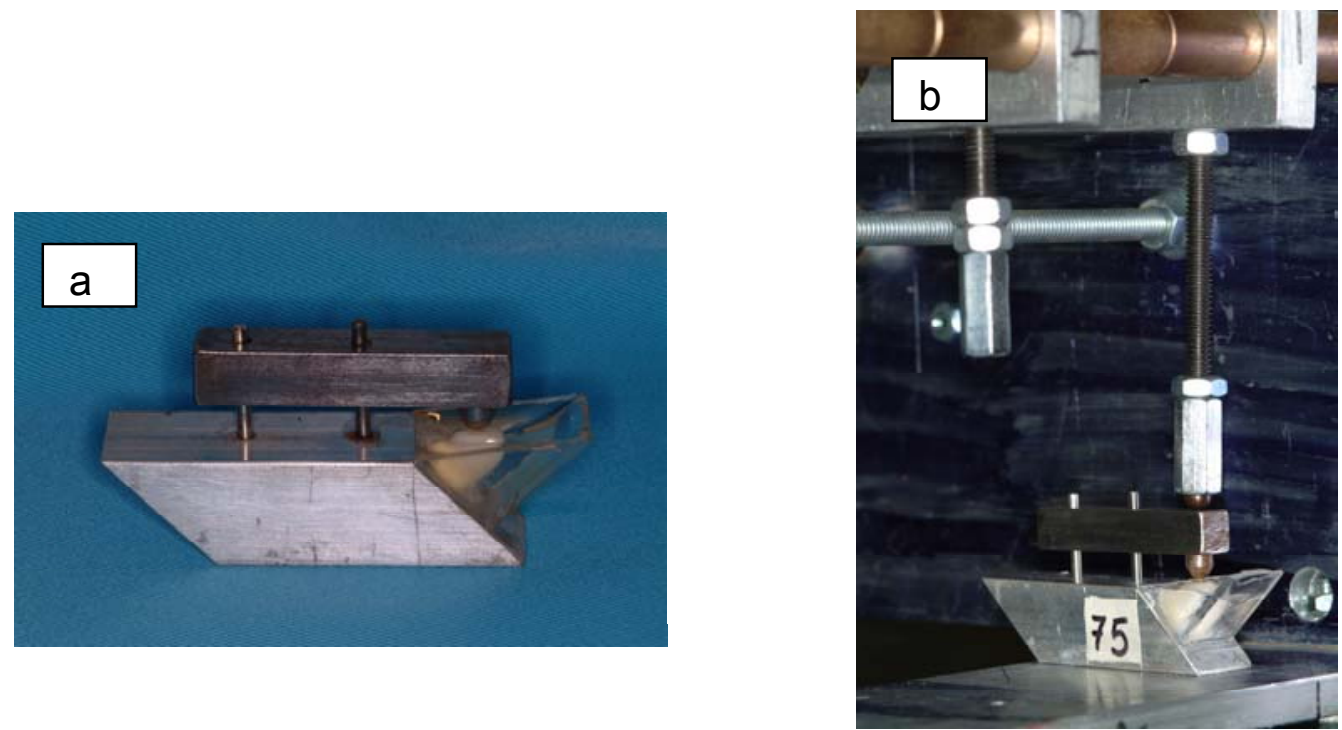

Figuras 4.5. Espécime montado na base de alumínio (a) e durante o teste de carga cíclica (b). 
Após o término do teste de carga cíclica os espécimes foram examinados no microscópio ótico a um aumento de 20X para certificar que nenhum dos espécimes sofrera fratura na raiz ou coroa.

\subsection{Teste com carga estática}

Para os testes com carga estática, os espécimes foram posicionados numa máquina de ensaios universal. Um cilindro foi posicionado $3 \mathrm{~mm}$ aquém da borda incisal das coroas, com contato tangenciando a superfície lingual, usando a mesma angulação de $135^{\circ}$ e pontos usados na carga cíclica, em relação ao longo eixo dos dentes (Figura 4.6). Uma força de compressão, no sentido vertical, a uma velocidade de $0,5 \mathrm{~mm} / \mathrm{min}$ com uma célula de carga de $10 \mathrm{KN}$, foi feita sobre os espécimes até causar falha dos mesmos. A força máxima foi registrada em $\mathrm{N}$.

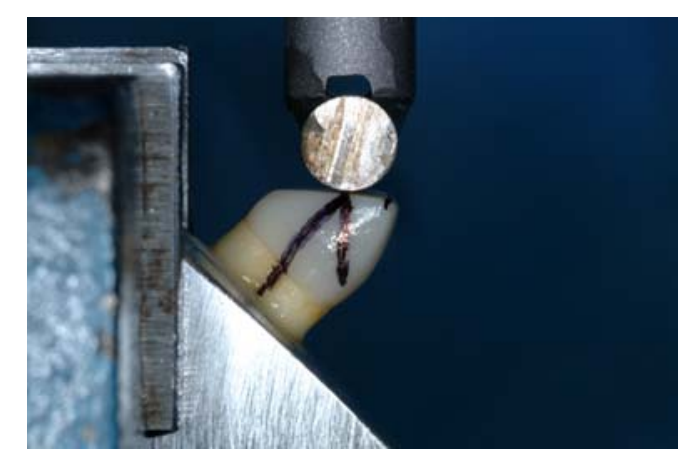

Figura 4.6. Espécime posicionado para o teste com carga estática na máquina de testes universal.

\subsection{3 - Análise do modo de fratura}

A análise do modo de fratura foi feita com auxílio de um microscópio ótico, com base para transluminação, com um aumento de 8X. As fraturas foram classificadas em função do nível da resina acrílica, que determinou o nível da crista óssea. Aquelas localizadas até $1 \mathrm{~mm}$ abaixo do nível mais superior da resina acrílica foram consideradas Supra-crestais (SC) ou reparáveis; e aquelas localizadas abaixo deste nível foram consideradas Infra-crestais (IC) ou catastróficas. 


\section{RESULTADOS}




\section{RESULTADOS}

Para os testes estatísticos foram usados os programas SPSS para Macintosh versão 11.0 e Pacotico para Windows versão 2.0.

Os valores individuais de resistência à fratura dos espécimes testados e seus respectivos grupos estão dispostos na Tabela 5.1. Os dados da estatística descritiva estão discriminados no Anexo 5 na tabela 5.2.

Tabela 5.1. Valores individuais de carga, média e desvio-padrão, necessários para fratura dos espécimes, expressos em $\mathrm{N}$.

\begin{tabular}{|c|c|c|c|c|c|c|c|c|c|c|c|}
\hline \multicolumn{2}{|c|}{$\begin{array}{l}\text { Grupo } 1 \\
\text { Zircônia } \\
\text { Controle }\end{array}$} & \multicolumn{2}{|c|}{$\begin{array}{c}\text { Grupo } 2 \\
\text { Zircônia } \\
\text { Experimental }\end{array}$} & \multicolumn{2}{|c|}{$\begin{array}{l}\text { Grupo } 3 \\
\text { Resina } \\
\text { Comosta } \\
\text { Controle }\end{array}$} & \multicolumn{2}{|c|}{$\begin{array}{c}\text { Grupo } 4 \\
\text { Resina } \\
\text { Composta } \\
\text { Experimental }\end{array}$} & \multicolumn{2}{|c|}{$\begin{array}{l}\text { Grupo } 5 \\
\text { Titânio } \\
\text { Controle }\end{array}$} & \multicolumn{2}{|c|}{$\begin{array}{c}\text { Grupo } 6 \\
\text { Titânio } \\
\text { Experimental }\end{array}$} \\
\hline Espec & Carga & Espec & Carga & Espec & Carga & Espec & Carga & Espec & Carga & Espec & Carga \\
\hline 10 & 1146 & 08 & 910 & 7 & 1043 & 03 & 822 & 02 & 903 & 01 & 751 \\
\hline 17 & 979 & 09 & 853 & 11 & 740 & 05 & 640 & 12 & 1138 & 04 & 783 \\
\hline 21 & 1043 & 14 & 989 & 19 & 1073 & 06 & 779 & 15 & 1040 & 13 & 836 \\
\hline 30 & 968 & 23 & 1097 & 26 & 1159 & 18 & 773 & 22 & 1087 & 16 & 692 \\
\hline 35 & 1100 & 32 & 987 & 29 & 735 & 25 & 868 & 24 & 922 & 20 & 898 \\
\hline 36 & 1176 & 34 & 690 & 33 & 1118 & 27 & 961 & 37 & 883 & 28 & 669 \\
\hline 41 & 1081 & 39 & 597 & 38 & 1065 & 31 & 601 & 44 & 1074 & 45 & 725 \\
\hline 46 & 1351 & 43 & 995 & 42 & 830 & 40 & 659 & 48 & 852 & 47 & 721 \\
\hline 49 & 1128 & 53 & 1048 & 52 & 1141 & 56 & 689 & 58 & 922 & 50 & 847 \\
\hline 55 & 1683 & 60 & 699 & 54 & 1511 & 57 & 830 & 59 & 1033 & 51 & 767 \\
\hline$\mu$ & 1165,50 & $\mu$ & 886,50 & $\mu$ & 1041,50 & $\mu$ & 762,20 & $\mu$ & 985,40 & $\mu$ & 768,90 \\
\hline$\Pi$ & 211,95 & $\pi$ & 170,62 & $\pi$ & 231,20 & $\pi$ & 113,63 & $\pi$ & 99,89 & $\pi$ & 72,95 \\
\hline
\end{tabular}

Os dados de resistência à fratura dos espécimes foram submetidos ao Teste de Levene (Anexo 5, Tabela 5.3) e não foram constatadas diferenças de variância de valores intra-grupos(Levene $=1,694 ; p=0,152)$. A análise estatística com o teste de ANOVA a 2 critérios, discriminados na Tabela 5.4, foi usada para analisar possíveis interações entre os tipos de pino, carga necessária para levar à fratura dos espécimes e a influência da carga cíclica. 
Tabela 5.4. Teste de ANOVA a 2 critérios, para comparação de carga à fratura, tipo de pinos e carga cíclica $(p<0,05)$.

\begin{tabular}{c|c|c|c|c|c}
\hline \hline $\begin{array}{c}\text { Fonte de } \\
\text { variação }\end{array}$ & $\begin{array}{c}\text { Soma dos } \\
\text { quadrados }\end{array}$ & $\begin{array}{c}\text { Graus de } \\
\text { liberdade }\end{array}$ & $\begin{array}{c}\text { Quadrado } \\
\text { Médio }\end{array}$ & F & Sig. \\
\hline $\begin{array}{c}\text { Tipos de } \\
\text { Pino }\end{array}$ & 254530,900 & 2 & 127265,450 & 4,903 & 0,011 \\
\hline $\begin{array}{c}\text { Carga } \\
\text { Cíclica }\end{array}$ & 1000525,06 & 1 & 1000525,06 & 38,552 & 0,000 \\
\hline Interação & 13083,63 & 2 & 6541,081 & 0,252 & 0,778 \\
\hline \hline
\end{tabular}

O Teste de ANOVA a 2 critérios mostrou que houve diferença entre os tipos de pinos, $(p<0,011)$, diferença entre os espécimes dos grupos-experimental e controle $(p<0,000)$; no entanto não houve interação entre o tipo de pino e a carga cíclica $(p=0,778)$ quanto aos valores de resistência à fratura com a carga estática.

Foram comparados as médias de resistência entre os grupos-controles ( 1,3 e 5$)$ e os grupos-experimentais (2, 4 e 6$)$ com o teste de ANOVA a 2 critérios $(p<0,05)$. Houve diferença entre o grupo 1 e 2 , entre o grupo 3 e 4 , e entre o grupo 5 e $6(p<0,05)$. A diminuição de valores de média resistência à fratura do grupo 1 para 0 grupo 2 foi de 23,91\%; entre os grupos 3 e 4 de 26,80\%, e entre os grupos 5 e 6 de $21,97 \%$.

Em seguida foi usado o Teste de Tukey para detectar entre quais grupos havia diferença, examinando interações entre tipos de pinos com aplicação de carga cíclica e resistência à fratura (Tabela 5.5).

Tabela 5.5. Teste de Tukey para detectar diferenças nos valores de resistência à fratura entre os grupos quanto ao tipo de pinos e influência da carga cíclica $(p<0,05)$.

\begin{tabular}{c|c|c}
\hline \hline Comparação entre-grupos & Diferença & Interpretação \\
\hline $\begin{array}{c}\text { Zircônia X Resina } \\
\text { Composta }\end{array}$ & 124,150 & Significante \\
\hline Zircônia X Titânio & 148,850 & Significante \\
\hline Resina Composta X Titânio & 24,7000 & Não Significante \\
\hline Experimental X Controle & 258,266 & Significante \\
\hline \hline
\end{tabular}

O teste de Tukey mostrou que o valor médio de resistência à fratura do grupo de zircônia foi maior do que os grupos de resina composta e titânio, independente da aplicação de carga cíclica. O valor do grupo de resina composta foi igual ao grupo de titânio, independente da aplicação de carga cíclica. 
Quando a aplicação de carga cíclica foi analisada, os valores dos grupos-controles foram maiores do que os dos grupos-experimentais.

As diferenças entre as médias de resistência à fratura entre os grupos testados podem ser melhores visualizadas na figura 5.1.

\section{Média de resistência à fratura dos dentes} restaurados

$\square$ Grupos-Controles $\square$ Grupos-Experimentais

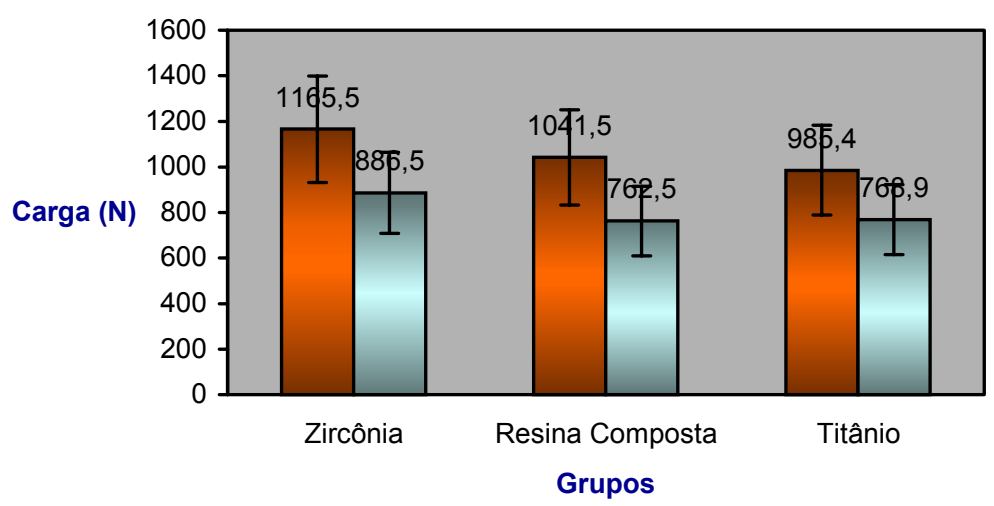

Figura 5.1. Comparação de médias de resistência à fratura $(N)$ entre os gruposexperimentais e controles.

Usando o Teste de Coeficiente de Correlação de Pearson, foram analisadas as correlações entre a carga necessária para a fratura e as dimensões MD e VL dos espécimes. Para a análise de dimensão MD X Carga, foi encontrada fraca, porém significante correlação $(r=0,26 ; p=0,044)$. Na análise entre dimensão $V L X$ Carga a correlação foi fraca e não significante $(r=0,24 ; p=0,059)$. Tabela 5.6. 
Tabela 5.6. Teste de Correlação de Pearson para análise de correlação entre as dimensões VL e MD dos espécimes e a carga necessária para suas fraturas.

\begin{tabular}{c|c|c|c}
\hline \hline Variáveis & Correlação de Pearson & Probabilidade & Número \\
\hline Carga X VL & 0,244 & 0,059 & 60 \\
\hline Carga X MD & & & 60 \\
\hline \hline
\end{tabular}

Os modos de fratura dos espécimes foram classificados em Supracrestais (SC) ou Reparáveis e Infra-crestais (IC) ou Catastróficos e estão descritos na Tabela 5.7.

Tabela 5.7. Modo de fratura dos espécimes submetidos à carga estática.

\begin{tabular}{c|c|c|c|c|c|c|c|c|c|c|c}
\hline \hline \multicolumn{2}{c|}{ Grupo 1 } & \multicolumn{2}{c|}{ Grupo 2 } & \multicolumn{2}{c|}{ Grupo 3 } & \multicolumn{2}{c|}{ Grupo 4 } & \multicolumn{2}{c|}{ Grupo 5 } & \multicolumn{2}{c}{ Grupo 6 } \\
\hline Espec & $\begin{array}{c}\text { Modo } \\
\text { de } \\
\text { fratura }\end{array}$ & Espec & $\begin{array}{c}\text { Modo } \\
\text { de } \\
\text { fratura }\end{array}$ & Espe & $\begin{array}{c}\text { Modo } \\
\text { de } \\
\text { fratura }\end{array}$ & Espec & $\begin{array}{c}\text { Modo } \\
\text { de } \\
\text { fratura }\end{array}$ & Espec & $\begin{array}{c}\text { Modo } \\
\text { de } \\
\text { fratura }\end{array}$ & $\begin{array}{c}\text { Espec } \\
\text { Modo } \\
\text { de } \\
\text { fratura }\end{array}$ \\
\hline $\mathbf{1 0}$ & IC & $\mathbf{0 8}$ & SC & $\mathbf{0 7}$ & SC & $\mathbf{0 3}$ & SC & $\mathbf{0 2}$ & SC & $\mathbf{0 1}$ & IC \\
\hline $\mathbf{1 7}$ & IC & $\mathbf{0 9}$ & SC & $\mathbf{1 1}$ & SC & $\mathbf{0 5}$ & SC & $\mathbf{1 2}$ & IC & $\mathbf{0 4}$ & IC \\
\hline $\mathbf{2 1}$ & SC & $\mathbf{1 4}$ & IC & $\mathbf{1 9}$ & SC & $\mathbf{0 6}$ & SC & $\mathbf{1 5}$ & SC & $\mathbf{1 3}$ & IC \\
\hline $\mathbf{3 0}$ & SC & $\mathbf{2 3}$ & SC & $\mathbf{2 6}$ & IC & $\mathbf{1 8}$ & SC & $\mathbf{2 2}$ & IC & $\mathbf{1 6}$ & SC \\
\hline $\mathbf{3 5}$ & IC & $\mathbf{3 2}$ & SC & $\mathbf{2 9}$ & SC & $\mathbf{2 5}$ & SC & $\mathbf{2 4}$ & IC & $\mathbf{2 0}$ & IC \\
\hline $\mathbf{3 6}$ & IC & $\mathbf{3 4}$ & SC & $\mathbf{3 3}$ & SC & $\mathbf{2 7}$ & IC & $\mathbf{3 7}$ & SC & $\mathbf{2 8}$ & IC \\
\hline $\mathbf{4 1}$ & SC & $\mathbf{3 9}$ & IC & $\mathbf{3 8}$ & SC & $\mathbf{3 1}$ & SC & $\mathbf{4 4}$ & IC & $\mathbf{4 5}$ & SC \\
\hline $\mathbf{4 6}$ & IC & $\mathbf{4 3}$ & IC & $\mathbf{4 2}$ & IC & $\mathbf{4 0}$ & SC & $\mathbf{4 8}$ & IC & $\mathbf{4 7}$ & SC \\
\hline $\mathbf{4 9}$ & IC & $\mathbf{5 3}$ & SC & $\mathbf{5 2}$ & IC & $\mathbf{5 6}$ & SC & $\mathbf{5 8}$ & SC & $\mathbf{5 0}$ & SC \\
\hline $\mathbf{5 5}$ & IC & $\mathbf{6 0}$ & IC & $\mathbf{5 4}$ & IC & $\mathbf{5 7}$ & SC & $\mathbf{5 9}$ & IC & $\mathbf{5 1}$ & SC \\
\hline \hline
\end{tabular}

Os modos de fratura são exemplificados nas figuras 5.2 a 5.5 . 


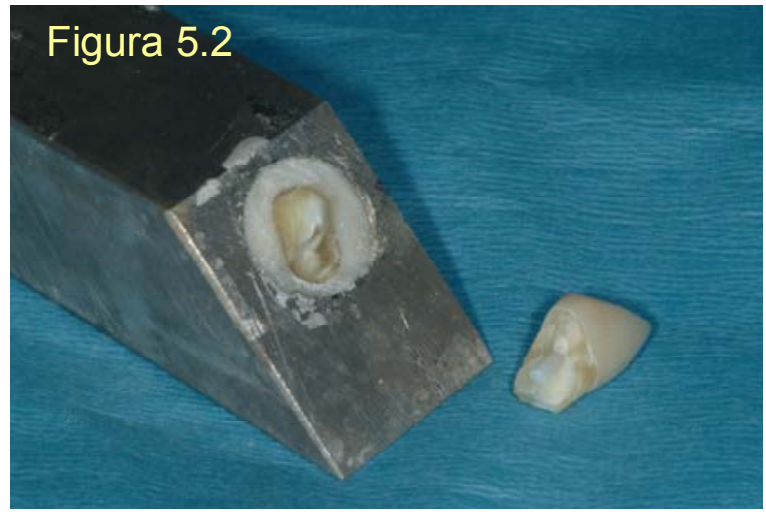

\section{Figura 5.3}

Figura 5.2 e 5.3. Modo de fratura Supra-crestal, nos grupos 2 e 4 respectivamente.
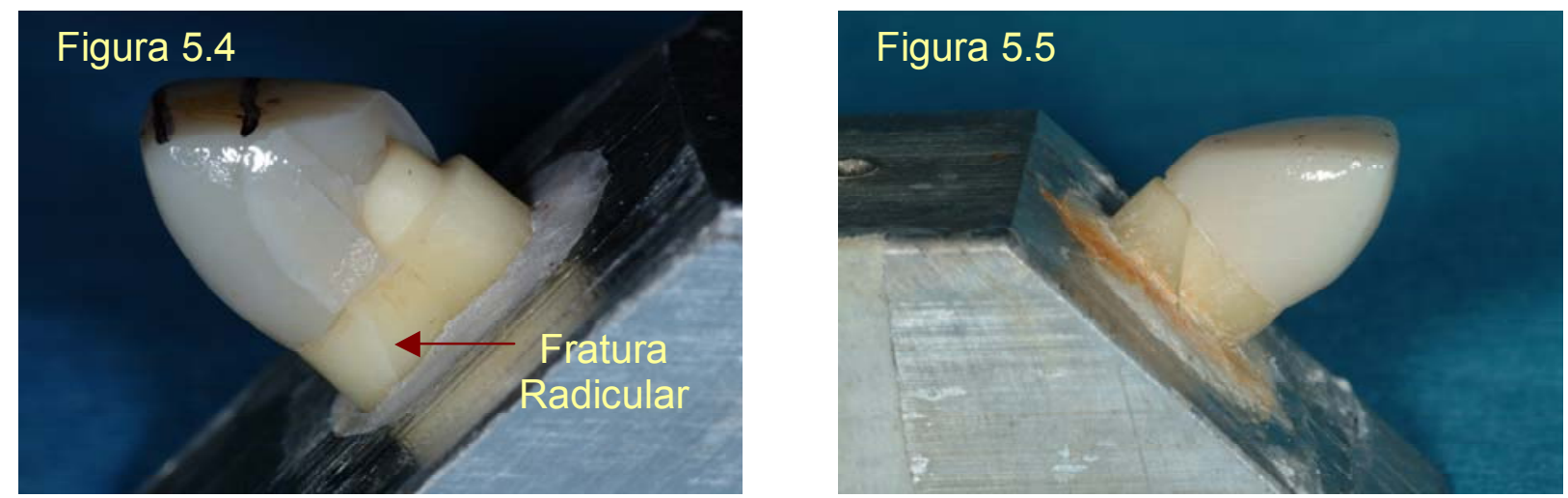

Figuras 5.4 e 5.5. $\quad$ Modo de fratura Infra-crestal nos grupos 5 e 6 , respectivamente.

Foi usado o Teste estatístico $Q$ Quadrado $\left(\chi^{2}\right)$ para detectar possível associação do modo de fratura com o tipo de pino, como descrito na Tabela 5.8.

Tabela 5.8. $\quad$ Teste $Q$ Quadrado $\left(\chi^{2}\right)$ para verificar associação entre os tipos de pinos e modo de fratura, independente da aplicação da carga cíclica.

\begin{tabular}{c|c|c|c}
\hline $\begin{array}{c}\text { Associação tipo de pino } \\
\mathbf{X} \\
\text { Modo de Fratura }\end{array}$ & Infra-Crestal & Supra-Crestal & Total \\
\hline $\begin{array}{c}\text { Pinos de Zircônia } \\
\text { Pinos de Resina Composta }\end{array}$ & 11 & 9 & 20 \\
\hline Pinos de Titânio & 11 & 9 & 20 \\
\hline Total & 27 & 33 & 60 \\
\hline & \multicolumn{2}{r|}{ Probabilidade $=0,885$} \\
\hline
\end{tabular}


Foi usado o teste Exato de Fischer para detectar possível associação entre modo de fratura com o tipo de pino, dependendo da aplicação de carga cíclica ou não. Tabelas 5.9 e 5.10 .

Tabela 5. 9. Teste Exato de Fischer para verificar associação entre os tipos de pinos e modo de fratura, nos grupos 1, 3 e 5, não submetidos à carga cíclica.

\begin{tabular}{c|c|c|c}
\hline \hline $\begin{array}{c}\text { Associação tipo de pino } \\
\mathbf{X} \\
\text { Modo de fratura sem carga cíclica }\end{array}$ & Infra-Crestal & Supra-Crestal & Total \\
\hline Pinos de Zircônia & 7 & 3 & 10 \\
\hline Pinos de Resina Composta & 4 & 6 & 10 \\
\hline Pinos de Titânio & 6 & 4 & 10 \\
\hline Total & 17 & 13 & 30 \\
\hline
\end{tabular}

Fischer $=1,9005$

Probabilidade $=0,3866$

Tabela 5.10. Teste Exato de Fischer para verificar associação entre os tipos de pinos e modo de fratura, nos grupos 2, 4 e 6, submetidos à carga cíclica.

\begin{tabular}{c|c|c|c}
\hline $\begin{array}{c}\text { Associação tipo de pino } \\
\mathbf{X} \\
\text { Modo de fratura com carga cíclica }\end{array}$ & Infra-Crestal & Supra-Crestal & Total \\
\hline Pinos de Zircônia & 4 & 6 & \\
\hline Pinos de Resina Composta & 1 & 9 & 10 \\
\hline Pinos de Titânio & 5 & 5 & 10 \\
\hline Total & 10 & 20 & 30 \\
\hline
\end{tabular}

Fischer $=3,900$

Probabilidade $=0,1422$

Em todas as análises usando o teste Exato de Fischer, não foi encontrada associação entre o modo de fratura e o tipo de pino, dos espécimes dos grupos-controles (Fischer=1,900 e $p=0,386$ ) e dos grupos-experimentais (Fischer $=3,900$ e $p=0,142$ ). 


\section{DISCUSSÃO}

Os resultados deste trabalho mostraram que a carga cíclica influenciou negativamente a resistência à fratura dos espécimes reconstruídos com todos os sistemas de núcleos intra-radiculares estudados $(p<0,044)$. No entanto, não houve interação entre o tipo de pino e diminuição de resistência à fratura após o ensaio $(p=0,778)$, ou seja, a diminuição de resistência à fratura não foi relacionada a um tipo especifico de pino; houve diminuição de resistência à fratura em todos os grupos testados. Na comparação entre o mesmo tipo de pino, os grupos-experimentais (2, 4 e 6) apresentaram valores de resistência à fratura inferiores aos espécimes dos gruposcontroles (1, 3 e 5)(Tabela 6.1 e 6.2, Gráfico 6.1). No grupo dos pinos de zircônia, houve uma redução de 23,91\%, no grupo dos pinos de resina composta, de $26,80 \%$ e no grupo de pinos titânio, de $21,97 \%$ nos valores de resistência à fratura após o teste de carga cíclica. Com isso pôde-se verificar que a carga de $250 \mathrm{~N}$, por 500.000 , ciclos a uma freqüência de $1,7 \mathrm{~Hz}$, foi suficiente para diminuir significativamente a resistência dos espécimes estudados à fratura. Não foram encontrados trabalhos na literatura para comparar a eficiência da carga cíclica, na resistência à fratura de dentes tratados endodonticamente; portanto, as reduções de valores de resistência podem ser explicadas pelo efeito do estresse nas estruturas onde foi aplicada a carga cíclica.

Quando os grupos foram comparados entre si, o grupo de pinos de zircônia mostrou valor de resistência à fratura maior do que os de resina composta e titânio, que foram iguais entre si independente da aplicação ou não da carga cíclica $(p<0,00)$. Seria esperado que diferentes materiais produzissem diferentes percentuais de diminuição de resistência, tanto pelo estresse transmitido à estrutura dentária, diminuindo a resistência dos dentes, quanto pela fadiga sofrida pelos materiais restauradores ${ }^{1,28,35,59,62,90}$. Assim, um material com alto módulo de elasticidade $(\Sigma)$ como, por exemplo, a zircônia, extremamente diferente do $\Sigma$ da dentina, causaria diminuição de resistência à fratura dos espécimes em maior proporção do que os materiais que têm menor $\Sigma$ tais como resina composta e titânio ${ }^{90}$. Por outro lado, a resistência flexural dos próprios materiais empregados na confecção dos pinos pode ter influenciado a resistência à fratura dos espécimes ${ }^{1,28,35,58,59,86}$. A zircônia tem valor de resistência flexural de $820 \mathrm{MPa}^{35}$, enquanto a resina composta reforçada por fibras é de $960 \mathrm{MPa}^{65}$, e o da liga de titânio é de $800 \mathrm{MPa}^{107}$. O $\sum$ da zircônia é de $200 \mathrm{GPa}^{86}$, da resina composta reforçada por fibra é de $13,5 \mathrm{GPa}^{65}$ e da liga de titânio é de $110 \mathrm{GPa}^{86}$. Assim, analisando os valores de resistência flexural dos conjuntos pinos e resistência à fratura dos espécimes, percebe-se que não há uma relação direta entre 
eles. Apesar de os pinos de resina composta apresentarem valores de resistência flexural maiores do que os de cerâmica, os valores de resistência à fratura dos espécimes restaurados com esses pinos foram menores do que os de zircônia no presente estudo. Os valores de $\Sigma$ apresentam uma relação direta parcial com a resistência à fratura, uma vez que, apesar de os pinos de resina composta apresentarem menores $\Sigma$, tiveram valores de resistência à fratura maiores do que os de titânio, que têm o valor de módulo de elasticidade intermediário, e menores do que os de zircônia que tem o maior valor de módulo de elasticidade dentre os materiais dos pinos testados no presente trabalho.

Outro fator que poderia ser relacionado à resistência à fratura, independente do pino utilizado, seriam as dimensões MD e VL dos dentes. No entanto, o teste de Correlação de Pearson mostrou haver fraca relação, ainda que estatisticamente significante, entre a dimensão MD e carga necessária à fratura $(r=0,26$ e $p=0,004)$, e fraca e não significante correlação entre a dimensão VL e carga necessária à fratura $(r=0,24$ e $p=0,059)$. Esses dados concordam com o trabalho de SIRIMAI, RIIS, MORGANO ${ }^{93}$, que tambem encontraram fraca, mas significante correlação entre a dimensão MD e resistência à fratura.

Analisando a relação entre o diâmetro, forma e textura de superfície dos pinos usados no corrente trabalho, pode-se perceber que os diâmetros foram muito próximos. Não foi possível padronizar o diâmetro, forma, e nem superfície dos pinos pré-fabricados entre os grupos o que excluiria esta possível variável do trabalho. Foram utilizados os pinos pré-fabricados disponíveis no mercado onde o fator determinante na escolha foi o material e não a forma. O fabricante dos pinos de cerâmica à base de zircônia indica o pino pré-fabricado com diâmetro de $1,7 \mathrm{~mm}$ para restaurar incisivos centrais superiores e caninos. Assim, foram escolhidos os modelos disponíveis dos outros sistemas de pinos pré-fabricados com diâmetros próximos ao dos pinos de zircônia. O maior diâmetro dos pinos de resina composta reforçada com fibra de vidro FibreKor é de 1,5mm, e o de titânio Aztech, que mais se aproxima destes dois valores, é de $1,65 \mathrm{~mm}$. No entanto, o diâmetro dos pinos de zircônia de $1,7 \mathrm{~mm}$ exige maior remoção de tecido dentário que os de resina composta e titânio, apesar do formato da extremidade apical destes pinos ser cônica. A forma cilíndrica dos pinos de resina composta, por outro lado, exigiu maior remoção de tecido dentário no terço apical. É sabido que há relação inversa entre quantidade de tecido dentário e resistência à fratura ${ }^{46,51,100}$. Os pinos de titânio exigiram remoção de tecido dentário similar ao do grupo de zircônia. No presente trabalho, não foi observada relação entre 
a quantidade de material removido e a resistência à fratura, concordando com estudos de AKKAYAN e GULMEZ ${ }^{2}$; BUTZ et al ${ }^{15}$; HEYDECKE, BUTZ, STRUB ${ }^{51}$; HEYDECKE et $\mathrm{al}^{50}$; STRUB, PONTIUS ${ }^{94}$. PONTIUS, HUTTER ${ }^{89}$ e RAYGOT; CHAI; JAMENSON ${ }^{91}$, não descreveram os diâmetros de forma clara, sendo assim impossível fazer comparações com esses trabalhos quanto a essa característica.

A textura superficial dos pinos, por sua vez, influencia sua retenção nos canais radiculares ${ }^{3}$. No presente trabalho, pôde-se observar uma relação indireta entre os pinos que apresentam maior retenção intra-radicular e resistência à fratura dos espécimes. Os valores de resistência à fratura dos grupos de titânio e resina composta foram iguais entre si e menores do que os do grupo de zircônia, enquanto os valores de retenção intra-radicular dos pinos de zircônia são menores do que os dos pinos de titânio e resina composta, que são iguais entre si. $^{3}$ Dessa maneira, os valores de retenção intra-radicular dos pinos pré-fabricados parece não exercer grande influência na resistência à fratura dos dentes tratados endodonticamente restaurados com os mesmos.

Analisando o material empregado na confecção dos núcleos de preenchimento, os grupos com pinos de resina composta e titânio tiveram o núcleo de preenchimento confeccionado em resina composta reforçada por fibras de vidro, enquanto no grupo de zircônia foi usada cerâmica vítrea. Estudos realizados por XIBLE, VALLE ${ }^{105}$; LUTHY, SCHÄRER ${ }^{69}$ mostraram que os valores de retenção dos núcleos de preenchimento de resina composta aos pinos metálicos com retenções mecânicas horizontais são similares aos valores de retenção oferecidos pelos pinos de zircônia à cerâmica vítrea; AL-HARBI, NATHANSON ${ }^{3}$ mostraram que os valores de retenção oferecidos pelos pinos de titânio com retenções horizontais para a resina são similares aos valores de retenção oferecidos pelos pinos de resina composta reforçados com fibra de vidro para a resina composta. É de se esperar, portanto, que esse fator não seja considerado responsável pela diferença de resistência à fratura entre os grupos. Ainda mais, $100 \%$ das falhas nos espécimes ocorreram por fratura radicular, acompanhada ou não de fratura da coroa, demonstrando a ótima estabilidade da união entre pinos pré-fabricados e núcleos de preenchimento.

A resistência de adesão entre o material resinoso utilizado na cimentação das coroas e os núcleos de preenchimento de resina composta e cerâmica vítrea, no corrente estudo, também são similares ${ }^{11,12,57} \mathrm{e}$, por conseguinte, não seria um fator que pudesse influenciar a resistência à fratura dos grupos testados. No entanto, resistência flexural da cerâmica vítrea é maior do que a da resina composta, 
sugere que a união entre a cerâmica vítrea e cimento resinoso e coroa de porcelana presentes nos grupos 1 e 2 seja mais estável do que a da resina composta/cimento resinoso e coroa de porcelana dos grupos 3, 4, 5 e 6, influenciando na resistência final à fratura dos espécimes.

Os valores de resistência à fratura maiores para os grupos restaurados com pinos pré-fabricados de cerâmica de zircônia (1 e 2) podem ser relacionados com a cimentação das coroas, decorrentes do fato de a parte coronária dos núcleos intraradiculares ter sido fabricada em cerâmica com alto teor de matriz vítrea (IPS Empress Cosmo). O tratamento com ácido hidrofluorídrico, feito previamente à cimentação das coroas, tanto na parte coronária dos núcleos intra-radiculares quanto na superfície interna das coroas, remove parte da matriz vítrea das cerâmicas e deixa uma superfície micro-retentiva na qual a aplicação de silano, que é uma molécula bifuncional, une-se em uma extremidade à porcelana e na outra à matriz resinosa do cimento. Nessa união, o silano pode funcionar como agente de selamento das microtrincas que são formadas na porcelana durante o ataque do ácido hidrofluorídrico. Tanto a maior retenção obtida entre os dois corpos cerâmicos quanto à formação de uma camada de baixo módulo de elasticidade entre dois materiais com alto módulo de elasticidade poderiam ser fatores que contribuíram para os altos valores de resistência neste grupo. A alta resistência de adesão e o papel de amortecimento da camada de cimento agiriam aumentando a capacidade de resistência dos espécimes à carga cíclica, não permitindo assim a fratura da coroa ou da reconstrução coronária antes do remanescente dental, durante o teste de carga estática, onde os espécimes são submetidos à carga até falha do sistema. Isso justificaria a ordem de resistência dos grupos do presente estudo, independente das variações dos materiais e métodos de confecção dos espécimes. O uso de cimento resinoso aliado à alta resistência das coroas cerâmicas à base de dissilicato de lítio e os altos valores de resistência mecânica da cerâmica de zircônia dos pinos pré-fabricados podem ter influenciado positivamente os valores mais altos encontrados nos grupos 1 e 2 .

A comparação dos resultados de resistência à fratura deste estudo com outros disponíveis na literatura deve ser feita em função da aplicação ou não da carga cíclica, embora nenhum dos trabalhos comparados tenha usado metodologia exatamente igual a este.

O grupo 1 (Zircônia controle=1165,5 $\pm 211,95 \mathrm{~N}$ ) apresentou valores maiores do que os achados por OTTL et al. ${ }^{84}$, de $193,5 \pm 57 \mathrm{~N}$. Esta diferença pode estar relacionada ao uso de dentes de acrílico pelos autores, com $1 \mathrm{~mm}$ de férula e 
coroas metálicas cimentadas com cimento de fosfato de zinco. Em outro trabalho, AKKAYAN, GULMEZ ${ }^{2}$ usaram pinos de zircônia e núcleo de preenchimento em resina composta, e acharam valores de resistência à fratura de $773,31 \mathrm{~N}$, mas com diferenças na metodologia, que explicariam as diferenças dos valores de resistência à fratura encontrados, tais como as coroas confeccionadas em metal, cimentadas com ionômero de vidro e os preparos sem efeito de férula.

O grupo 3 (Resina Composta Controle $=1041,5 \pm 231,20 \mathrm{~N}$ ) só pode ser comparado diretamente com um grupo do estudo de AKKAYAN, GULMEZ ${ }^{2}$, que usaram pinos intra-radiculares de resina composta reforçado por fibra de vidro/núcleo de preenchimento em resina composta e obtiveram valor de resistência à fratura de $734,82 \mathrm{~N}$, o qual foi bem menor que o presente estudo. A diferença pode ser devido ao uso de coroas metálicas que foram cimentadas com ionômero de vidro em remanescentes coronários dentais sem férula. No mesmo trabalho, num segundo grupo, foi usado pino intra-radicular de resina composta reforçado por fibra de quartzo/núcleo de preenchimento em resina composta, cujo comportamento é similar ao dos pinos reforçados por fibra de vidro, o qual apresentou resistência à fratura de $893,76 \mathrm{~N}$, também menor que no presente estudo. No trabalho de OTTL et al. ${ }^{84}$, foi incluído um grupo restaurado com pino intra-radicular de resina epóxica reforçado por fibra de carbono e núcleo de preenchimento de resina composta, cujo resultado foi bem inferior $(312,5 \pm 58 \mathrm{~N})$ do que o do presente estudo, também utilizando dentes de acrílico, com efeito de férula de 1,0mm e coroas metálicas cimentadas com cimento de fosfato de zinco. Em outro trabalho, MARTINEZ-INSUA, RILO, SANTANA ${ }^{73}$ reconstruíram pré-molares com pinos intra-radiculares de resina composta reforçados por fibra de carbono, e a resistência à fratura foi de $103,7 \pm 53 \mathrm{~kg}$ ou $1016,26 \pm 520,38 \mathrm{~N}$, o que foi bem similar ao presente estudo, apesar de naquele terem sido usados prémolares e coroas metálicas, cimentadas com cimento de fosfato de zinco, com a carga incidindo em $45^{\circ}$ de angulação em relação ao longo eixo dos dentes, na cúspide vestibular.

O grupo 5 (Titânio Controle=985,4 $\pm 113,63 \mathrm{~N}$ ) pode ser comparado com um mesmo grupo do trabalho de AKKAYAN, GULMEZ ${ }^{(2)}$, que obtiveram valores de $656,20 \mathrm{~N}$ de resistência à fratura, bem inferior ao do presente estudo. As possíveis diferenças podem ser atribuídas ao uso de coroas metálicas cimentadas com cimento de ionômero de vidro e ao fato de os espécimes não possuírem efeito férula.

Vários trabalhos foram encontrados para comparação com os grupos que foram submetidos à carga cíclica. $\mathrm{O}$ grupo 2 (Zircônia 
Experimental=886,5 $\pm 170,62 \mathrm{~N}$ ) apresentou resultado médio superior ao mesmo grupo do trabalho de HEYDECKE et al. ${ }^{50}$, que obtiveram um valor de $512 \mathrm{~N}$. As diferenças entre esses trabalhos foram que neste último foram usadas coroas metálicas cimentadas com cimento de fosfato de zinco e submetidas à carga térmica e mecânica de $30 \mathrm{~N}$ por 1,2 milhão de ciclos. A mesma metodologia foi usada por BUTZ et al. ${ }^{15}$, que também acharam resultados inferiores, de $378 \pm 64 \mathrm{~N}$, para o mesmo grupo. STRUB et al. ${ }^{94}$ usaram 1,2 milhão de ciclos de mastigação e pinos de cerâmica onde foram cimentados núcleos de preenchimento pré-fabricados em cerâmica vítrea e encontraram uma resistência à fratura de $1494,3 \pm 333,5 \mathrm{~N}$. No mesmo trabalho, confeccionaram um grupo de pino de cerâmica/núcleo de preenchimento em cerâmica vítrea fundida e obtiveram valor de $1146,7 \pm 1182 \mathrm{~N}$. No trabalho de PONTIUS, HUTTER $^{89}$, os autores submeteram os espécimes restaurados com pinos de zircônia/núcleo de preenchimento em cerâmica vítrea a 1,2 milhão de ciclos, em

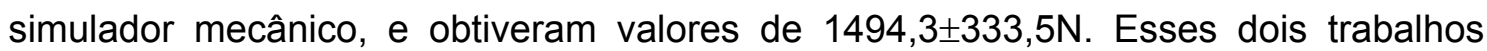
mostraram valores de resistência maiores do que os do presente trabalho. Nesses dois últimos, os espécimes foram cobertos com copings de cerâmica Procera de $0,6 \mathrm{~mm}$ de espessura cimentados com cimento resinoso. Os autores relataram que vários copings fraturaram durante a teste de carga cíclica e estática, indicando que os valores poderiam ter sido ainda maiores. Enfim, as diferenças entre este e os estudos revisados podem ser atribuídas aos parâmetros dos ensaios, material de confecção das coroas, cimento utilizado para cimentar as coroas além das dimensões dos preparos.

O grupo 4 (Resina Composta Experimental=762,20 $\pm 113,63 \mathrm{~N}$ ) mostrou valores menores do que os obtidos por STRUB et al. ${ }^{94}(1146,7 \pm 182,6 \mathrm{~N})$, Neste grupo, aos pinos intra-radiculares de resina composta reforçada por fibra, foram cimentados núcleo de preenchimento em cerâmica pré-fabricada. Esses espécimes foram submetidos a 1,2 milhão de ciclos em um simulador de mastigação. Os espécimes foram cobertos com copings de cerâmica pura Procera, cimentados com cimento resinoso. Utilizando a mesma programação de teste de carga cíclica que a do trabalho anterior, PONTIUS, HUTTER ${ }^{89}$ obtiveram também valor médio de resistência à fratura de $1146,7 \pm 182,6 \mathrm{~N}$. Os resultados foram superiores do presente estudo, mas com diferenças em programação de ensaio de fadiga, diferentes máquinas e, ainda, inclusão de fadiga térmica.

O grupo 6 (Titânio Experimental=768,9 $\pm 72,95 \mathrm{~N}$ ) apresentou valores de resistência maiores que HEYDECKE et al. ${ }^{50}$ que obtiveram valores de resistência de 
$503 \mathrm{~N}$, e BUTZ et al. ${ }^{15}$, que obtiveram $425 \pm 155 \mathrm{~N}$, mas menores que os resultados de outro trabalho de HEYDECKE, BUTZ, STRUB ${ }^{51}$, cujos valores de resistência à fratura obtidos foram de $1038 \mathrm{~N}$. As diferenças podem ser explicadas pelas diferentes metodologias, diferentes programações de ensaio com carga cíclica entre os estudos citados e o corrente estudo.

Além dos fatores citados anteriormente, de maneira geral, as diferenças de resistência à fratura dos espécimes do presente estudo, em relação aos trabalhos revisados, podem ser atribuídos a: 1) - a taxa de sobrevivência dos espécimes do presente trabalho foi de $100 \%$, em todos os grupos, o que permitiu avaliação com teste estatístico paramétrico (ANOVA a 2 critérios) da resistência à fratura com teste de carga estática em todos eles, não causando um desvio padrão alto, nem uma média de resistência baixa, uma vez que quando algum espécime falhou durante a teste de carga cíclica dos outros estudos, foi-lhe designado valor zero (0); 2- o ataque com ácido hidrofluorídrico, e posterior uso de silano na porção coronária dos núcleos intra-radiculares de zircônia previamente à cimentação, aumentaram a estabilidade da união entre o núcleo de preenchimento e coroa de porcelana, e provavelmente a resistência e estabilidade do conjunto; 3- nos grupos 3, 4, 5 e 6, previamente à cimentação das coroas, tanto o núcleo de preenchimento em resina quanto o remanescente coronário foram tratados com ácido fosfórico a 37\%. Após a secagem do preparo, integralmente, foi feito umedecimento das superfícies dos dentes antes da aplicação do adesivo. A não-observância desse detalhe pode levar à aplicação de adesivo dentinário em dentina ressecada, o que diminui sensivelmente a resistência de adesão com o material resinoso ${ }^{48,87}$. Nos trabalhos revisados na literatura onde foi comparada a resistência à fratura de dentes tratados endodonticamente restaurados com diferentes tipos de pinos submetidos à carga cíclica, somente em dois foi usada a cimentação resinosa ${ }^{89,94}$, e não foi especificado o uso deste procedimento.

Outra possível diferença pode ter sido devido ao tipo de dentes usados. No presente trabalho, foram usados dentes humanos e, para minimizar os problemas inerentes, os dentes foram distribuídos por amostragem estratificada, ou seja, após a amputação da porção coronária e preparo inicial dos dentes, os remanescentes foram medidos nas dimensões MD e VL e divididos em 6 grupos. Em seguida, as dimensões foram tratadas estatisticamente para testar a homogeneidade entre os grupos e ratificar que suas médias de dimensões eram estatisticamente iguais ${ }^{2,15}$. Esse fato mostrou hvaer uma fraca, mas significante correlação positiva entre medidas MD e resistência à carga estática $(r=0,26 ; p=0,04)$. Esse pode ter sido um fator significante 
se comparadas às mesmas dimensões, por exemplo com os incisivos centrais ou quaisquer outros dentes com diâmetros diferentes, mas não disponíveis para avaliação de outros trabalhos.

Os dentes que recebem núcleos intra-radiculares são sempre tratados endodonticamente, resultando em pequena, mas não negligenciável perda de tecido dental. É de consenso geral que a inclusão desse passo deve ser feita para simular cuidadosamente todos os parâmetros clínicos. Nesse aspecto, para evitar um possível efeito do eugenol na polimerização do sistema resinoso, na cimentação do pino préfabricado intra-radicular, foi utilizado um cimento de obturação à base de hidróxido de cálcio.

Obedecendo a uma tendência atual na restauração de dentes tratados endodonticamente com pinos pré-fabricados e núcleos de preenchimento, foi incorporado um efeito de férula de $1,5 \mathrm{~mm}$ para os espécimes deste estudo. Não existe dúvida de que uma coroa cria um efeito de férula sobre o núcleo intra-radicular quando suas margens contornam um colar de dentina saudável ${ }^{4,9,41,50,66,99}$.

É também discutida a restauração final com coroas em espécimes que foram reconstruídos com núcleos intra-radiculares ${ }^{70,92,93}$. Tal procedimento poderia mascarar o efeito da reconstrução com diferentes técnicas de núcleos intraradiculares. Outra conclusão referente ao uso de coroas nos trabalhos revisados seria que realmente existem poucas diferenças entre a grande quantidade de tipos de pinos pré-fabricados e sistemas de reconstrução quando uma restauração final, a ser confeccionada, for uma coroa total ${ }^{52}$. No entanto, testar espécimes sem coroas não simularia uma condição clínica ${ }^{99}$. Baseado nessa suposição, todos os espécimes do presente trabalho foram restaurados com coroas totais. Ainda considerando o recobrimento total, o material da coroa e tipo de cimento podem influenciar nos resultados do trabalho, uma vez que o cimento do tipo fosfato de zinco ou ionômero de vidro, ou a coroa de porcelana feldspática, podem falhar antes do conjunto pino préfabricado/núcleo de preenchimento, alterando os resultados de resistência à fratura.

Um outro fator que não é mencionado em nenhum dos trabalhos revisados é a proporção entre o tamanho do pino intra-radicular e a coroa. De maneira geral, esses dados, quando descritos, são variáveis nos diversos estudos revisados, embora indiquem sempre que essa proporção fosse maior do que 1 , o que é considerado essencial para um bom prognóstico de resistência do dentes tratados 
endodonticamente restaurados com núcleos intra-radiculares e coroas totais ${ }^{31,32,93}$. No presente trabalho, a proporção foi em média de 1,3.

A taxa de sobrevivência de todos os grupos ao teste de carga cíclica foi de $100 \%$, demonstrando que apesar de a carga cíclica ter diminuído a resistência à fratura, ela não foi suficiente para causar fraturas durante o teste de carga cíclica assegurando, assim, que todos os espécimes pudessem ser submetidos à carga estática. Isso implica em obtenção de dados para um tratamento estatístico que permitiu análise paramétrica e principalmente igualdade de variância entre os grupos, com um desvio-padrão satisfatório. No presente trabalho, isso foi conseguido com a programação de um teste de carga cíclica não destrutivo, o qual objetivou testar a resistência à fratura dos espécimes após o teste. Antes do teste final, estudos pilotos foram feitos a fim de que fossem determinados parâmetros para a pesquisa tais como o valor da carga e número de ciclos necessários para se obter diminuição na resistência residual dos dentes submetidos à carga, sem no entanto destruí-los.

A freqüência dos ciclos é outro dado importante na programação do ensaio de fadiga. A mais usada pela maioria dos autores é de 1,3 a $2 \mathrm{~Hz}^{15,28,50,51,91,94}$. No presente trabalho, o emprego das coroas de porcelana pura, onde a carga cíclica incidiu, contra-indicou o uso de uma máquina do tipo servo-hidráulica e freqüência acima de $2 \mathrm{~Hz}$, uma vez que os impactos ou sua velocidade, provocados pela ponta indutora de carga, poderiam causar fratura na porcelana. As desvantagens no uso de freqüências desta magnitude é que as mesmas exigem um tempo exagerado para se conduzir maior número de ciclos do que o do presente estudo.

Outro aspecto considerado na programação do teste de carga cíclica foi o ângulo de incidência de $135^{\circ}$, assim como para o posterior teste sob carga estática nos espécimes, que concordou com todos os trabalhos avaliados na literatura ${ }^{2,5,9,15,28,40,50,51,52,67,71,89,94,102}$.

Para a execução dos estudos-pilotos foram observados dados obtidos nos trabalhos de BATES,STAFFORD,HARRISON ${ }^{10}$; HEYDECKE et al. ${ }^{50}$; MANNOCCI, FERRARI; WATSON ${ }^{71}$; WISKOTT, NICHOLLS, BELSER ${ }^{107}$. Assim, inicialmente, foram programados $10^{6}$ ciclos e carga de $133 \mathrm{~N}$ para o teste de carga cíclica. Ao final do ensaio, os espécimes foram submetidos à carga estática, e foi observado que não havia diferença entre a resistência dos espécimes experimentais do grupo-piloto e a do grupo-controle com esta programação. A decisão final quanto à programação da carga e número de ciclos nos espécimes só foi tomada após vários grupos de estudos- 
piloto, quando finalmente foram detectadas diferenças de resistência à fratura à carga estática entre os grupos de pinos pré-fabricados de titânio submetido à carga cíclica e o grupo-controle. Diferente da maioria dos trabalhos revisados, neste trabalho um dos objetivos ao se programarem os parâmetros do teste de carga cíclica, foi verificar qual a carga e quantos ciclos seriam necessários para reduzir significantemente os valores de resistência dos grupos sem levá-los à fratura durante o teste de carga cíclica e, posteriormente, medir a resistência residual dos dentes à carga estática. A falta de grupos-controle nos estudos revisados ${ }^{15,50,51,56,71,89,91,92,94}$ não permite visualizar, nos grupos testados, o efeito de diminuição na resistência à fratura de dentes tratados endodonticamente reconstruídos com núcleos intra-radiculares e coroas, que a carga cíclica provoca. Parâmetros tais como 1,2 milhão de ciclos com $30 \mathrm{~N}$ de carga utilizados em diversos estudos podem indicar igualdade de resistência entre sistemas de núcleos intra-radiculares estudados. Isso permitiria inferir que, ao final de 1,2 milhão de ciclos, que grosseiramente pode corresponder tanto a 1,6 quanto a 20 anos de serviço clínico, dependendo do indivíduo ${ }^{107}$, os sistemas continuarão funcionando no ambiente oral. Esta programação não responde se com 1,5 milhão o sistema $A$ sofre enfraquecimento $50 \%$ maior do que o sistema B. Essa pergunta não pode ser respondida com testes que não provocam diminuição de resistência, os quais só objetivam responder se a um determinado e incerto tempo de serviço clínico os sistemas são ou não diferentes entre si. Os parâmetros de número de ciclos e freqüência do presente estudo concordam com as normas sugeridas por WISKOTT, NICHOLLS, BELSER ${ }^{107}$ os quais sugerem que nos testes onde se tenta medir o limite de resistência à fadiga, o estresse aplicado se localiza definitivamente abaixo do limite elástico do material e o intervalo de fadiga fica entre $10^{4}$ e $10^{7}$ ciclos. Os testes de laboratório conduzidos até este intervalo de ciclos, dentro das limitações dos mesmos, fazem aproximação de comportamento clínico e podem, ser considerados conclusivos para o direcionamento de estudos clínicos.

MANNOCCI, FERRARI, WATSON ${ }^{71}$, obtiveram $90 \%$ de taxa de sobrevivência para os grupos de pinos de fibra de quartzo e carbono-quartzo, bastante similares aos do presente estudo, mas apenas 50\% para um grupo onde foram usados pinos de zircônia/núcleos de preenchimento com resina composta. Em relação a este último grupo, DIETSCHI, ROMELLI, GORETTI ${ }^{28}$ obtiveram 12,5\%, e 100\% para os espécimes restaurados com pinos de zircônia e resina composta reforçada por fibras respectivamente. Nesses dois estudos, especificamente, alguns parâmetros dos testes foram muito diferentes do presente estudo, o que poderia justificar as diferenças de taxa de sobrevivência encontradas. No estudo de MANNOCCI, FERRARI, WATSON ${ }^{71}$, 
foram confeccionados espécimes com preparos sem efeito de férula, e os núcleos de preenchimento no grupo de zircônia foram feitos de resina composta, enquanto no trabalho de DIETSCHI, ROMELLI, GORETTI ${ }^{28}$ não foram usadas coroas como restauração final.

O modo de fratura encontrado nos 3 grupos deste trabalho foi diversificado (Tabela 5.7). A classificação das fraturas utilizada considerou que se uma fratura radicular fosse localizada até $1,0 \mathrm{~mm}$ abaixo da crista óssea, a raiz do dente poderia ser recuperável (Supra-crestal). O nível da resina acrílica utilizada para incluir os dentes foi considerado como o nível ósseo. Na avaliação da associação entre o tipo de pino e modo de fratura (Tabela 5.8, 5.9 e 5.10), o teste Q-quadrado $\left(\chi^{2}\right)$ não detectou nenhum tipo de associação $\left(\chi^{2}=4,484\right.$ e $\left.p=0,885 ; n=60\right)$ quando não foi considerada a aplicação de carga cíclica, assim como também não houve diferença quando os grupos foram tratados separadamente, tanto para os grupos-controles (Fischer=1,900 e $p=0,386 ; n=30$ ) quanto para os grupos-experimentais (Fischer=3,90 e $p=0,142 ; n=30)$.

A comparação dos resultados do modo de fratura do presente trabalho com os trabalhos disponíveis na literatura é dificultada pelas variadas descrições para modo de fratura: HEYDECKE, BUTZ, STRUB ${ }^{51}$ classificam as fraturas como catastróficas quando localizadas abaixo do nível de resina acrílica usada na inclusão dos espécimes, e reparáveis quando localizadas acima deste nível. PONTIUS, HUTTER ${ }^{89}$ classificaram as fraturas como vertical, horizontal e oblíqua, dependendo da direção da fratura na raiz.

Não foram feitas comparações com trabalhos que utilizaram dentes bovinos $^{551}$, dentes de acrílico ${ }^{84}$, e naqueles onde não foi relatado o modo de fratura dos espécimes ${ }^{94}$.

Pela revisão de literatura não se encontraram trabalhos relativos a espécimes reconstruídos com pinos de zircônia e cerâmica vítrea sem uso de carga cíclica para serem comparados os modos de fratura. No entanto, quando considerado o grupo 2 (Zircônia Experimental) do presente estudo, encontrou-se $60 \%$ de modo de fratura reparável (SC) e $40 \%$ de fraturas catastróficas (IC). Em relação a esses tipos de fratura, respectivamente, foram estes os resultados encontrados: HEYDECKE, BUTZ, STRUB ${ }^{51} 86,5 \%$ e 13,75\%; BUTZ et al. ${ }^{15} 80,25 \%$ e 19,75\%. As diferenças podem novamente serem atribuídas às diferenças de metodologia nos trabalhos analisados em relação ao presente estudo. 
Para o grupo de resina composta reforçada por fibras, no presente estudo foi achado de 10\% (grupo 4) até $40 \%$ (grupo 3) de fraturas catastróficas (IC) e $60 \%$ (grupo 4) a 90\%(grupo 3) de fraturas reparáveis (SC). AKKAYAN, GULMEZ ${ }^{3}$ relataram $70 \%$ de fraturas catastróficas (IC) e $30 \%$ de fraturas reparáveis (SC) para espécimes reconstituídos com pinos de resina composta reforçados por fibras e núcleo de resina composta submetidos à carga estática. Já PONTIUS, HUTTER ${ }^{89}$ relataram $100 \%$ de modo de fratura ao nível da junção amelo-dentinária para os espécimes submetidos à carga cíclica e subseqüentemente à carga estática o que, pela análise dos esquemas ilustrativos disponíveis no artigo revisado, sugere um modo de fratura recuperável.

Ao considerar os grupos de titânio, no presente estudo foram encontrados percentuais variando de $50 \%$ (grupo 6) até 60\% (grupo 5) de fraturas catastróficas (IC) e 40\% (grupo 5) a 50\% (grupo 6) de fraturas reparáveis (SC). AKKAYAN, GULMEZ ${ }^{2}$ encontraram 100\%, e RAYGOT, CHAI, JAMESON ${ }^{91} 70 \%$ a $80 \%$ de fratura catastrófica para espécimes reconstituídos com pinos de titânio submetidos à carga estática até a fratura. HEYDECKE, BUTZ, STRUB ${ }^{51}$ relataram 100\%, enquanto em outro trabalho HEYDECKE et al. ${ }^{50}$ encontraram $93,75 \%$ e BUTZ et ll $^{15}$ obtiveram $86,5 \%$ de fraturas catastróficas para espécimes reconstruídos com pinos de titânio e resina composta submetidos à carga cíclica e em seguida estática, e $0 \%$, $6,25 \%$ e $13,5 \%$ para modo de fratura reparáveis para os mesmo estudos respectivamente.

Os dados do presente trabalho não estão de acordo com os trabalhos revisados na literatura, e essas diferenças podem estar relacionadas com a metodologia, tais como o tipo de coroa e cimentação destas, presença de efeito férula e proporção pino intra-radicular/coroa.

No entanto, de modo geral, há uma concordância na tendência de padrão de fraturas infra-crestais ou catastróficas em espécimes restaurados com pinos pré-fabricados metálicos. O modo de fratura dos espécimes em que foram usados pinos de zircônia em associação com porcelana vítrea ainda não está bem esclarecido, uma vez que não houve concordância na tendência dos percentuais entre os trabalhos estudados e os do presente trabalho. Por outro lado, parece haver uma tendência em ocorrer fratura do tipo supra-crestal ou reparável em espécimes restaurados com pino intra-radicular de resina composta reforçado por fibra após o teste de carga cíclica. 
Os resultados de estudos in vitro, comparando a resistência à fratura com ou sem teste de carga cíclica, de dentes tratados endodonticamente reconstruídos com pinos pré-fabricados e núcleo de preenchimento de resina composta e núcleos metálicos fundidos, indicam que essas modalidades de tratamento trazem resultados semelhantes. Os mesmos resultados foram relatados, independentemente, em estudos in vivo. Considerando que o sucesso de dentes tratados endodonticamente restaurados com ambas as técnicas, pinos pré-fabricados metálicos e núcleos de preenchimento em resina composta, e núcleos metálicos fundidos ser acima de $85 \%$ em 10 anos, deve-se questionar se o uso de qualquer outro sistema proverá, no mínimo, resultados similares em termos de longo prazo.

Experimentos clínicos controlados são o último tipo de procedimento para criar evidências na validação de procedimentos de tratamento. Resultados clínicos encorajadores têm sido relatados com o uso de pino intra-radicular de resina composta reforçado por fibra de carbono, os quais foram os primeiros a serem desenvolvidos ${ }^{26,36}$.

Embora os resultados de resistência à fratura, taxa de sobrevivência à carga cíclica e modo de fratura dos núcleos estéticos tenham sido iguais ou superiores aos dos pinos pré-fabricados de titânio e núcleo de preenchimento de resina composta no presente trabalho, experimentos clínicos com taxas de sucesso em prazos mais longos são necessários para endossar o uso dos mesmos.

Este estudo objetivou obter evidências, em nível laboratorial, do uso de sistemas de pinos pré-fabricados e núcleos de preenchimento, o que, em última instância, pode direcionar o uso destes materiais para experimentos clínicos, com riscos minimizados. 
7 CONCLUSÕES 


\section{CONCLUSÕES}

Dentro das limitações e condições deste estudo in vitro, as seguintes conclusões podem ser obtidas:

1- A aplicação de carga cíclica diminuiu a resistência de dentes tratados endodonticamente reconstruídos com pinos préfabricados estéticos e metálicos, restaurados com coroa de porcelana pura.

2- $\quad$ As taxas de sobrevivência dos dentes tratados endodonticamente reconstruídos com pinos estéticos e metálicos, restaurados com coroas de porcelana pura, foram iguais entre si após a aplicação de carga cíclica não destrutiva.

3- Os valores de resistência à fratura de dentes tratados endodonticamente reconstruídos com pinos pré-fabricados de resina composta reforçados com fibra de vidro e metálicos, restaurados com coroas de porcelana pura foram iguais entre si, mas menores do que a daqueles restaurados com pinos préfabricados de zircônia, independente de aplicação de carga cíclica.

4- $O$ modo de fratura de dentes tratados endodonticamente reconstruídos com núcleos intra-radiculares estéticos ou metálicos, recobertos com coroas de porcelana pura foi igual, independente do tipo do núcleo intra-radicular utilizado ou aplicação de carga cíclica.

5- Quanto maior a dimensão MD de dentes tratados endodonticamente reconstruídos com núcleos intra-radiculares estéticos e metálicos, restaurados com coroas de porcelana, maior foi a carga necessária para causar fratura destes. 
ANEXOS 


\section{ANEXOS}

ANEXO 1- Dados da estatística descritiva das dimensões MD e VL de todos os grupos. (Tabela 4.2 e 4.3 )

Tabela 4.2. Estatística descritiva dos valores das dimensões MD dos espécimes.

\begin{tabular}{|c|c|c|c|c|c|c|c|c|}
\hline & \multirow{2}{*}{$n$} & \multirow{2}{*}{ Média } & \multirow{2}{*}{$\begin{array}{l}\text { Desvio } \\
\text { Padrão }\end{array}$} & \multirow{2}{*}{$\begin{array}{l}\text { Erro } \\
\text { Padrão }\end{array}$} & \multicolumn{2}{|c|}{$\begin{array}{c}\text { Intervalo de confiança } \\
\text { de } 95 \%\end{array}$} & \multirow[b]{2}{*}{ Mínimo } & \multirow{2}{*}{ Máximo } \\
\hline & & & & & $\begin{array}{l}\text { Limite } \\
\text { Inferior }\end{array}$ & $\begin{array}{l}\text { Limite } \\
\text { Superior }\end{array}$ & & \\
\hline 1 & 10 & 5,481 & 0,488 & 0,154 & 5,131 & 5,830 & 4,60 & 6,37 \\
\hline 2 & 10 & 5,366 & 0,294 & 0,930 & 5,155 & 5,576 & 4,93 & 5,76 \\
\hline 3 & 10 & 5,449 & 0,372 & 0,117 & 5,182 & 5,715 & 4,90 & 6,07 \\
\hline 4 & 10 & 5,239 & 0,345 & 0,109 & 4,992 & 5,485 & 4,63 & 5,74 \\
\hline 5 & 10 & 5,453 & 0,357 & 0,113 & 5,197 & 5,708 & 4,87 & 6,07 \\
\hline 6 & 10 & 5,338 & 0,382 & 0,120 & 5,064 & 5,611 & 4,83 & 6,00 \\
\hline Total & 60 & 5,387 & 0,371 & 0,047 & 5,291 & 5,483 & 4,60 & 6,37 \\
\hline
\end{tabular}

Tabela 4.3. Estatística descritiva dos valores das dimensões VL dos espécimes.

\begin{tabular}{|c|c|c|c|c|c|c|c|c|}
\hline & \multirow[b]{2}{*}{$n$} & \multirow[b]{2}{*}{ Média } & \multirow{2}{*}{$\begin{array}{l}\text { Desvio } \\
\text { Padrão }\end{array}$} & \multirow{2}{*}{$\begin{array}{l}\text { Erro } \\
\text { Padrão }\end{array}$} & \multicolumn{2}{|c|}{$\begin{array}{c}\text { Intervalo de confiança } \\
\text { de } 95 \%\end{array}$} & \multirow[b]{2}{*}{ Mínimo } & \multirow[b]{2}{*}{ Máximo } \\
\hline & & & & & $\begin{array}{l}\text { Limite } \\
\text { Inferior }\end{array}$ & $\begin{array}{l}\text { Limite } \\
\text { Superior }\end{array}$ & & \\
\hline 1 & 10 & 7,790 & 0,251 & 0,794 & 7,610 & 7,969 & 7,26 & 7,99 \\
\hline 2 & 10 & 7,566 & 0,322 & 0,101 & 7,335 & 7,796 & 7,12 & 7,99 \\
\hline 3 & 10 & 7,598 & 0,525 & 0,166 & 7,222 & 7,973 & 6,39 & 7,99 \\
\hline 4 & 10 & 7,767 & 0,306 & 0,964 & 7,554 & 7,986 & 7,11 & 7,98 \\
\hline 5 & 10 & 7,756 & 0,255 & 0,807 & 7,573 & 7,938 & 7,14 & 7,99 \\
\hline 6 & 10 & 7,659 & 0,315 & 0,099 & 7,433 & 7,885 & 7,10 & 7,97 \\
\hline Total & 60 & 7,689 & 0,338 & 0,437 & 7,601 & 7,776 & 6,39 & 7,99 \\
\hline
\end{tabular}


ANEXO 2- Teste de Levene para detectar homogeneidade de variância entre os grupos formados. (Tabela 4.4). Teste de ANOVA a 1 critério para verificar possíveis diferenças nas dimensões MD e VL dos espécimes dos grupos. (Tabela 4.5 e 4.6).

Tabela 4.4. Teste de Levene para confirmar igualdade de variância entre grupos $(p<0,05)$.

\begin{tabular}{c|c|c|c|c}
\hline \hline Dimensões & Levene Statistic & df1 & df2 & Sig. \\
\hline MD & 1,248 & 5 & 66 & 0,297 \\
\hline VL & 2,277 & 5 & 66 & 0,057 \\
\hline \hline
\end{tabular}

Tabela 4.5. Teste de ANOVA a 1 critério para verificar igualdade nas dimensões MD dos espécimes $(p<0,05)$.

\begin{tabular}{c|c|c|c|c|c}
\hline \hline & $\begin{array}{c}\text { Soma dos } \\
\text { quadrados }\end{array}$ & $\mathbf{d f}$ & $\begin{array}{c}\text { Média dos } \\
\text { quadrados }\end{array}$ & $\mathbf{F}$ & Sig. \\
\hline Entre grupos & 0,181 & 5 & 0,036 & 0,224 & 0,951 \\
\hline Intra grupos & 10,644 & 66 & 0,161 & & \\
\hline Total & 10,825 & 71 & & & \\
\hline \hline
\end{tabular}

Tabela 4.6. Teste de ANOVA a 1 critério para verificar a igualdade das dimensões VL dos espécimes $(p<0,05)$.

\begin{tabular}{c|c|c|c|c|c}
\hline \hline & $\begin{array}{c}\text { Soma dos } \\
\text { quadrados }\end{array}$ & $\mathbf{d f}$ & $\begin{array}{c}\text { Média dos } \\
\text { quadrados }\end{array}$ & $\mathbf{F}$ & Sig. \\
\hline Entre grupos & 0,632 & 5 & 0,126 & 0,851 & 0,519 \\
\hline Intra grupos & 9,810 & 66 & 0,149 & & \\
\hline Total & 10,443 & 71 & & & \\
\hline \hline
\end{tabular}


ANEXO 3- Programa do forno de fundição Vulcan 3-550 usado para evaporação da cera dos pinos de zircônia e coroas (Tabela 4.8) e do forno EP 500 Ivoclar usado para a termo-injeção de cerâmica IPS Empress Cosmo nos pinos de zircônia (Tabela 4.9).

Tabela 4.8. Programa do forno Vulcan 3-550 para evaporação da cera.

\begin{tabular}{c|c|c|c}
\hline \hline Temperatura Inicial & Graus por minuto & Temperatura final & Tempo de espera \\
\hline $0^{\circ} \mathrm{C}$ & $5^{\circ} \mathrm{C}$ & $250^{\circ} \mathrm{C}$ & 30 minutos \\
\hline $250^{\circ} \mathrm{C}$ & $5^{\circ} \mathrm{C}$ & $850^{\circ} \mathrm{C}$ & 01 hora \\
\hline \hline
\end{tabular}

Tabela 4.9. Programa $\mathrm{n}^{\circ} 13$ do forno EP 500 Ivoclar para termo-injeção de porcelana.

\begin{tabular}{c|c|c|c|c|l|l}
\hline \hline $\begin{array}{l}\text { Temperatura } \\
\text { Inicial }\end{array}$ & Graus por minuto & $\begin{array}{l}\text { Temperatura } \\
\text { final }\end{array}$ & N & H & V1 & V2 \\
\hline $700^{\circ} \mathrm{C}$ & $60^{\circ} \mathrm{C}$ & $900^{\circ} \mathrm{C}$ & 0 & 10 & $500^{\circ} \mathrm{C}$ & $900^{\circ} \mathrm{C}$ \\
\hline \hline
\end{tabular}


ANEXO 4- Programa do forno EP 500 Ivoclar para a termo-injeção das coroas de porcelana pura IPS Empress 2 (Tabela 4.10), e programa do forno de porcelana Vita Vacumat 40 para aplicação da massa de glaze nas coroas de porcelana IPS Empress 2 pela técnica de maquiagem (Tabela 4.11).

Tabela 4.10. Programa $n^{\circ} 11$ do forno EP 500 Ivoclar para termo-injeção de porcelana IPS Empress 2.

\begin{tabular}{c|c|c|c|c|l|l}
\hline \hline $\begin{array}{c}\text { Temperatura } \\
\text { Inicial }\end{array}$ & Graus por minuto & $\begin{array}{l}\text { Temperatura } \\
\text { final }\end{array}$ & N & H & V1 & V2 \\
\hline $700^{\circ} \mathrm{C}$ & $60^{\circ} \mathrm{C}$ & $920^{\circ} \mathrm{C}$ & 0 & 20 & $500^{\circ} \mathrm{C}$ & $920^{\circ} \mathrm{C}$ \\
\hline \hline
\end{tabular}

Tabela 4.11. Programação do forno de porcelana Vita Vacumat 40 para aplicação da massa de glaze nas coroas de porcelana IPS Empress 2 pela técnica de maquiagem.

\begin{tabular}{c|c|c|c|l|l}
\hline $\begin{array}{l}\text { Temperatura } \\
\text { Inicial }\end{array}$ & $\begin{array}{l}\text { Taxa de elevação } \\
\text { da temperatura } \\
\text { (minutos) }\end{array}$ & $\begin{array}{l}\text { Temperatura } \\
\text { final }\end{array}$ & $\begin{array}{l}\text { Tempo de } \\
\text { espera na } \mathbf{t}_{\mathrm{f}} \\
\text { (minutos) }\end{array}$ & $\begin{array}{l}\text { V1 } \\
\text { Vácuo } \\
\text { Inicial }\end{array}$ & $\begin{array}{l}\text { V2 } \\
\text { Vácuo } \\
\text { Final }\end{array}$ \\
\hline $403^{\circ} \mathrm{C}$ & $56^{\circ} \mathrm{C}$ & $799^{\circ} \mathrm{C}$ & $1.00 \mathrm{~min}$ & $403^{\circ} \mathrm{C}$ & $799^{\circ} \mathrm{C}$ \\
\hline \hline
\end{tabular}


ANEXO 5- Estatística descritiva dos valores de resistência à fratura dos seis grupos testados (Tabela 5.2). Teste de Levene para testar homogeneidade de variância entre as médias dos grupos $(p<0,05)$.

Tabela 5.2. Estatística descritiva para valores de resistência à fratura à carga estática, expressos em $\mathrm{N}$.

\begin{tabular}{|c|c|c|c|c|c|c|c|c|}
\hline & \multirow[b]{2}{*}{$\mathrm{n}$} & \multirow[b]{2}{*}{ Média } & \multirow{2}{*}{$\begin{array}{l}\text { Desvio } \\
\text { Padrão }\end{array}$} & \multirow{2}{*}{$\begin{array}{l}\text { Erro } \\
\text { Padrão }\end{array}$} & \multicolumn{2}{|c|}{$\begin{array}{c}\text { Intervalo de confiança } \\
\text { de } 95 \%\end{array}$} & \multirow[b]{2}{*}{ Mínimo } & \multirow[b]{2}{*}{ Máximo } \\
\hline & & & & & $\begin{array}{l}\text { Limite } \\
\text { Inferior }\end{array}$ & $\begin{array}{l}\text { Limite } \\
\text { Superior }\end{array}$ & & \\
\hline 1 & 10 & 1165,50 & 211,95 & 67,02 & 1013,87 & 1317,12 & 968,00 & 1683,00 \\
\hline 2 & 10 & 886,50 & 170,62 & 53,95 & 764,44 & 1008,55 & 597,00 & 1097,00 \\
\hline 3 & 10 & 1041,50 & 231,20 & 73,11 & 876,10 & 1206,89 & 735,00 & 1511,00 \\
\hline 4 & 10 & 762,20 & 113,63 & 35,93 & 680,91 & 843,48 & 601,00 & 961,00 \\
\hline 5 & 10 & 985,40 & 99,89 & 31,59 & 913,93 & 1056,86 & 852,00 & 1138,00 \\
\hline 6 & 10 & 768,90 & 72,95 & 23,07 & 716,70 & 821,09 & 669,00 & 898,00 \\
\hline Total & 60 & 935,00 & 27,46 & 27,46 & 880,05 & 989,94 & 597,00 & 1683,00 \\
\hline
\end{tabular}

Tabela 5.3. Teste de Levene para testar a homogeneidade de variância entre as médias dos grupos $(p<0,05)$.

\begin{tabular}{c|c|c|c}
\hline \hline Teste de Levene & df1 & df2 & Sig. \\
\hline 1,694 & 5 & 54 & 0,152 \\
\hline \hline
\end{tabular}


REFERÊNCIAS BIBLIOGRÁFICAS 


\section{REFERÊNCIAS BIBLIOGRÁFICAS*}

1. AHMAD, I. Yttrium-partially stabilized zirconium dioxide posts: an approach to restoring coronally compromised nonvital teeth. Int $\mathbf{J}$ Periodont Restorat Dent, v.18, n.5, p.455-65, Oct. 1998

2. AKKAYAN, B.; GÜLMES, T. Resistance to fracture of endodonticaly treated teeth restored with different post systems. J Prosth Dent, v.87, n.4, p.431-7, Apr. 2002.

3. AL-HARBI, F.; NATHANSON, D. In vitro assessment of retention of four esthetic dowels to resin core foundation and teeth. J Prosth Dent, v.90, n.6, p.547-55, Dec. 2003.

4. AQUILINO, S.A.; CAPLAN, D.J. Relationship between crown placement and the survival of endodonticaly treated teeth. J Prosth Dent, v.87, n.3, p.256-63, Mar. 2002.

5. ASSIF, D. et al. Effect of post design on resistance to fracture of endodonticaly treated teeth with complete crowns. J Prosth Dent, v.69, n.1, p.36-40, Jan. 1993.

6. ASMUSSEN, E.; PEUTZFELDT, A.; HEITMANN, T. Stiffness, elastic limit, and strength of newer types of endodontic posts. J Dent, v.27, n.5, p.275-8, May 1999.

7. ATTAR, N.; TAM, L.E.; McCOMB, D. Mechanical and physical properties of contemporary dental luting agents. J Prosth Dent, v.89, n.2, p.127-34, Feb. 2003.

8. BARABAN, D.J. Immediate restoration of pulpless ${ }^{1}$ teeth. J Prosth Dent, v.28, n.6, p.607-12, Dec. 1972.

9. BARKHORDAR, R.A.; RADKE, R.; ABBASI, J. Effect of metal collars on resistance of endodontically treated teeth to root fracture. J Prosth Dent, v.61, n.6, p.676-8, June 1989.

10. BATES, J.F.; STAFFORD, G.D.; HARRISON, A. Masticatory function - a review of literature (II) Speed of movement of the mandible, rate of chewing and forces developed in chewing. J Oral Reha, v.2, n.4, p.349-61, Oct. 1975.

\footnotetext{
* Normas recomendadas para o uso no âmbito da Universidade de São Paulo, com base no documento "Referências Bibliográficas: exemplos", emanado do Conselho Supervisor do Sistema Integrado de Bibliotecas da USP em reunião de 20 de Setembro de 1990.
} 
11. BONA, A.D.; ANUSAVICE, K.J.; HOOD, J.A.A. Effect of ceramic surface treatment on tensile bond strength to a resin cement. Int J Prosth, v.15, n.3, p.248-53, May/June 2002.

12. BONA, A.D.; SHEN, C.; ANUSAVICE, K.J. Work of adhesion of resin on treated lithia disilicate-based ceramic. Dent Mater, v.20, n.5, p.338-44, May 2004.

13. BOUILLAGUET, S. et al. Microtensile bond strength between adhesive cements and root canal dentin. Dent Mater, v.19, n.3, p.199-205, Mar. 2003.

14. BRYANT, R.W.; MAHLER, D.B. Modulus of elasticity in bending of composites and amalgams. J Prosth Dent, v.56, n.2, p.243-8, Aug. 1986.

15. BUTZ, F. et al. Survival rate and fracture strength of endodonticaly treated maxillary incisors with moderate defects restored with different post-and-core systems: an in vitro study. Int J Prosth, v14, n.1, p.58-64 Jan. 2001.

16. CALES, B.; STEFANI, Y.; LILLEY, E. Long-term in vivo and in vitro aging of a zircônia ceramic used in orthopaedy. J Biom Mat Res, v.28, n.5, p.61924, May 1994

17. CARVALHO, R.M. et al. A review of polimerization contraction: the influence of stress development versus stress relief. Oper Dent, v. 21, n.1, p.17-24, Jan. 1996.

18. CAROSSA, S. et al. Influence of posts and cores on light transmission through different all-ceramic crowns: spectrophotometric and clinical evaluation. Int $\mathbf{J}$ Prosth, v.14, n.1. Jan. 2001.

19. CHANDLER, N.P.; QUALTROUGH, A.J.E., PURTON, D.G. Comparison of two methods for the removal of root canal posts. Quint Int, v.34, n.7, p.534-6, July/Aug. 2003.

20. CHO, G.C. et al. Diametral and compressive strength of dental core materials. J Prosth Dent, v.82, n.3, p.272-6, Sept. 1999.

21. CHRISTEL, P. et al. Mechanical properties and short-term in-vivo evaluation of yttrium-oxide-partially-stabilized zirconia. J Biomed Mat Res, v.23, p.4561, Jan. 1989.

22. COHEN, B.I. et al. Cyclic fatigue of five endodontic post designs supported by four core materials. J Prosth Dent, v.78, n.5, p.458-64, Nov. 1997.

23. COHEN, B.I. et al. Retention of a core material supported by three post head designs. J Prosth Dent, v.83, n.6, p.624-8, June 2000.

24. COONEY, J.P.; CAPUTO, A.A.; TRABERT, K.C. Retention and stress distribution of tapered-end endodontic posts. J Prosth Dent, v.55, n.5, p.540-6, May 1986. 
25. COSMOPOST E IPS EMPRESS PASTILLAS COSMO. Perfil Técnico. Ivoclar Vivadent AG, Schaan/Liechtensteinlar, 2001.

26. CREUGERS, N.H.J.; MENTINK, A.G.B.; KAYSER, A.F. An analysis of durability data on post and core restorations. J Dent, v.21, n.5, p.281-4, Oct. 1993.

27. DEAN, J.P.; JEANSONNE, B.G.; SARKAR, N. In vitro evaluation of a carbon fiber post. J Endod, v.24, n.12, p.807-10, Dec. 1998.

28. DIETSCHI, D.; ROMELLI, M.; GORETTI, A. Adaptation of adhesive posts and cores to dentin after fatigue testing. Int J Prosth, v.10, n.6, p.498-507, Nov/Dec. 1997.

29. ECKERBOM, M.; MAGNUSSON, T. Restoring endodontically treated teeth: a survey of current opinions among board-certified prosthodontics and general dental practitioners in Sweden. Int J Prosth, v.14, n.3, p.245-9. May/June 2001.

30. ELLNER, S.; BERGENDAL, T.; BERGMAN, B. Four post-and-core combinations as abutments for fixed single crowns: a prospective up to 10 -year study. Int $\mathbf{J}$ Prosth, v.16, n.3, p.249-54, May/June 2003

31. FERNANDES, A.S.; DESSAI, G.S. Factors affecting the fracture resistance of post-core reconstructed teeth: a review. Int J Prosth, v.14, n.4, p.355-63, July/Aug. 2001.

32. FERNANDES, A.S.; SHETTY, S.; COUTINHO, I. Factors determining post selection: a literature review. J Prosth Dent, v.90, n.6, p.556-62, Dec. 2003.

33. FERRARI, M. et al. Bonding of all-porcelain crowns: structural characteristics of the substrate. Dent Mater, v.17, n.2, p.156-64, Mar. 2001.

34. FERRARI, M. et al. Bonding to root canal: structural characteristics of the substrate. Am J Dent, v.13, n.5, p.255-60, Oct. 2000.

35. FISCHER, H.; RENTZSCH, W.; MARX, R. Elimination of low-quality ceramic posts by proof testing. Dent Mater, v.18, n.10, p.570-5, Oct. 2001.

36. FREDRIKSSON, M. et al. A retrospective study of 236 patients with teeth restored by carbon fiber-reinforced epoxy resin posts. J Prosth Dent, v.80, n.2, p.151-7, Aug. 1998.

37. FREEMAN, M.A. et al. Leakage associated with load fatigue-induced preliminary failure of full crowns pladed over three different post and core systems. J Endod, v.24, n.1, p.26-32, Jan. 1998.

38. GALLO, J.R., HENDERSON, M.E.; BURGESS, J.O. Shear bond strength to moist and dry dentin of four dentin bonding systems. Am J Dent, v.13, n.5, p. 26770, Oct. 2000. 
39. GARVIE, R.C.; HANNINK, R.H.; PASCOE, R.T. Ceramic steel? Nature, v.258-9, n.25, p.703-4, Dec. 1975.

40. GATEAU, P.; SABEK, M.; DAILEY, B. Fatigue testing and microscope evaluation of post and core restorations under artificial crowns. J Prosth Dent, v.82, n.3, p.341-7, Sept. 1999.

41. GEGAUFF, A.G. Effect of crown lengthening and ferrule placement on static load failure of cemented cast post-cores and crowns. J Prosth Dent, v.84, n.2, p.169-79, Aug. 2000.

42. GOLDBERG, A.J.; BURSTONE, C.J. The use of continuous fiber reinforcement in dentistry. Dent Mater, v.8, n.3, p.197-202, May 1992.

43. GOLDMAN, M.; De VITRE, R.; NATHANSON, D. An SEM study of posts cemented with an unfilled resin. J Dent Res, v.66, n.2, p.1003-5, July 1984.

44. GOODACRE, C.J. et al. Clinical complications in fixed prosthodontics. J Prosth Dent, v.90, n.1, p.31-41, July 2003.

45. GUZZATO, M. et al. Strength, fracture toughness and microstructure of a selection of all-ceramic materials. Part II. Zirconia-based dental ceramics. Dent Mat, v. 20, n.7, p.449-56 July 2004.

46. GUZY, G.E; NICHOLLS, J.I. In vitro comparison of intact endodontically treated teeth with and without endo-post reinforcement. J Prosth Dent, v.42, n.1, p.39-44, July 1979.

47. HAGGE, M.S.; WONG, R.D.M.; LINDEMUTH, J.S. Effect of three root canal sealers on the retentive strength of endodontic posts luted with a resin cement. Int Endodont J, v.35, n.4, p.372-8, Apr. 2002.

48. HASHIMOTO, M. et al. The effect of hybrid layer thickness on bond strength: demineralized dentin zone of the hybrid layer. Dent Materials, v.16, n.6, p.406-11, Nov. 2000.

49. HEALEY, H.J. Restoration of the effectively treated pulpless tooth. J Prosth Dent, v.4, n.6, p.842-9, Nov. 1954.

50. HEYDECKE, G.; STRUB, J.R. Fracture strength after dynamic loading of endodotically treated teeth restored with different post-and-core systems. J Prosth Dent, v.87, n.4, p.438-45, Apr. 2002.

51. HEYDECKE, G.; BUTZ, F.; STRUB, J.R. Fracture strength and survival rate of endodonticaly treated maxillary incisors with approximal cavities after restoration with different post and core systems: an in vitro study. J Dent, v.29, n.6, p.427-33, Aug. 2001. 
52. HEYDECKE, G.; PETERS, M.C. The restoration of endodonticaly treated, singlerooted teeth with cast or direct posts and cores: a systematic review. J Prosth Dent, v.87, n.4, p.380-6, Apr, 2002.

53. HOLMES, D.C.; DIAZ-ARNOLD, A.M.; LEARY, J.M. Influence of post dimension on stress distribution in dentin. J Prosth Dent, v.76, n.2, p.140-7, Fev. 1996.

54. HSU,YB; et al. Effect of core bonding on fatigue failure of compromised teeth. Int J Prosth, v.15, n.2, p.175-8, Mar/Apr. 2002.

55. ISIDOR, F.; BRØNDUM, K.; RAVNHOLT, G. The influence of post length and crown ferrule length on the resistance to cyclic loading of bovine teeth with prefabricated titanium posts. Int J Prosth, v.12, n.1, p.78-82, Jan. 1999.

56. ISIDOR, F.; ÖDAMAN, P.; BRØNDUM, K. Intermittent loading of teeth restored using prefabricated carbon fiber posts. Int J Prosth, v.9, n.2, p.131-6, Mar/Apr, 1996.

57. JARDEL, V. et al. Correlation of topography to bond strength of etched ceramic. Int J Prosth, v.12, n.1, p.59-64, Jan. 1999.

58. JEONG, S-M.; LUDWIG, K.; KERN, M. Investigation of the fracture resistance of three types of zircônia posts in all-ceramic post-and core restorations. Int $\mathbf{J}$ Prosth, v.15, n.2, p.154-8 Mar/Apr. 2002.

59. KAKEHASHI, Y. et al. A new all-ceramic post and core system: clinical, technical and in vitro results. Int J Periodont Rest Dent, v.18, n.6, p.587-93 Nov/Dec. 1998.

60. KILIARIDIS, S.; KJELLBERG, H.; WENNEBERG, B. The relationship between maximal bite force, bite force endurance, and facial morphology during growth. Acta Odont Scand, v.51, n.5, p.323-31 Oct. 1993.

61. KINNEY, J.H. et al. Hardness and Young's modulus of human peritubular and intertubular dentine. Archs oral Biol, v.41, n.1, p.9-13, Jan. 1996.

62. KOUTAYAS, S.O.; KERN, M. All-ceramic posts and cores: the state of the art. Quint Int, v.30, n.6, p.283-92, June 1999.

63. KUSUNOKI, M. et al. The efficacy of dentine adhesive to sclerotic dentine. $\mathbf{J}$ Dent, v.30, n.1, p.91-7 Jan. 2002.

64. KWIATKOWSKI, S.J.; GELLER, W. A preliminary consideration of the glassceramic dowel post and core. Int J Prosth,, v.2, n.1, p.51-5, Jan. 1989.

65. LASSILA, L.V.J. et al. Flexural properties of fiber reinforced root canal posts. Dent Mater, v.20, n.1, p.29-36, Jan. 2004. 
66. LIBMAN, W.J.; NICHOLLS, J.I. Load fatigue of teeth restored with cast posts and cores and complete crowns. Int J Prosth, v.8, n.2, p.155-61, Mar. 1995.

67. LONEY, R.W.; MOULDING, M.B.; RITSCO, R.G. The effect of load angulation on fracture resistance of teeth restored with cast post and cores and crowns. Int J Prosth, v.8, n.3, p.247-51, May/June 1995.

68. LUTHARDT, R.G. et al. Reliability and properties of ground Y-TZP-Zirconia ceramics. J Dent Research, v.81, n.7, p.487-91, July 2002.

69. LÜTHY, H.; LOEFFEL, O.; SCHÄRER, P. Zirconia posts and cores: factors influencing retention. J Dent Res, v.74, n.3, p.939, Mar. 1999. IAbstract n.228/

70. MARSHALL Jr, G.W. et al. The dentin substrate: structure and properties related to bonding. J Dent, v.25, n.6, p.441-58, Nov. 1997.

71. MANNOCCI, F.; FERRARI, M.; WATSON, T.F. Intermittent loading of teeth restored using quartz fiber, carbon-quartz fiber and zirconium dioxide ceramic root canal posts. J Ades Dent, v. 1, n.2, 153-8, Feb. 1999.

72. MANNOCCI, F. et al. Three-year clinical comparison of survival of endodonticaly treated teeth restored with either full cast coverage or with direct composite restoration. J Prosth Dent, v.88, n.3, p.297-301, Sept. 2002.

73. MARTINEZ-INSUA, A. et al. Comparison of the fracture resistances of pulpless teeth restored with a cast post and core or carbon-fiber post with a composite core. J Prosth Dent, v.80, n.5, p. 527-32, Nov. 1998.

74. MENTINK, A.G.B.; MEEUWISSEN, R.; KÄYSER, A.F. Survival rate and failure characteristics of the all metal post and core restoration. J Oral Reha, v.20, n.7, p.455-61, Dec. 1993.

75. MILLER, B.H. et al. Bond strength between cements and metals used for endodontic posts. Dent Mater, v.14, n.5, p.312-20, Sept. 1998.

76. MORGANO, S.M.; BRACKETT, S.E. Foundation restorations in fixed prosthodontics: current knowledge and future needs. J Prosth Dent, v.82, n.6, p.643-57, Dec. 1999.

77. NAKAMURA, T. et al. Influence of abutment substrate and ceramic thickness on the colour of heat-pressed ceramic crowns. J Oral Reha, v.29, n.12, p.805-9, Dec. 2002.

78. NERGIZ, I. et al. Bond strengths of five tapered root posts regarding the post surface. J Oral Reha, v.29, n.4, p.330-5, April 2002.

79. NEWMAN, M.P. et al. Fracture resistance of endodonticaly treated teeth restored with composite posts. J Prosth Dent, v.89, n.4. p.360-7, Apr. 2003 
80. NIKAIDO, T. et al. Bond strengths to endodonticaly-treated teeth. Am J Dent, v.12, n.4, p.177-80, Aug. 1999.

81. O'KEEFE, K.L. et al. Bond strength between cements and metals used for endodontic posts. Dent Mater, v.14, n.5, p.312-20, Sept. 1998

82. O'KEEFE, K.L; POWERS, J.M. Adhesion of resin composite core materials to dentin. Int J Prosth, v.14, n.5, p. 451-6. Sept/Oct. 2001.

83. ORR, J.F.; MITCHELL, C.A. The evaluation of post-retained crowns using a custom-designed fatigue machine. J Oral Reha, v.23, n.3, p.179-85, Mar. 1996.

84. OTTL, P. et al. Fracture characteristics of carbon fiber, ceramic and nonpalladium endodontic post systems at monotonously increasing loads. J Oral Reha, v.29, n.2, p.175-83, Feb. 2002.

85. PEST, L.B. et al. Adhesive post-endodontic restorations with fiber posts: push-out tests and SEM observations. Dent Materials, v.18, n.11, p.596-602, Nov. 2002.

86. PICONI, C.; MACCAURO, G. Zirconia as a ceramic biomaterial. Biomater, v.20, n.1, p.1-25, Jan. 1999.

87. PIOCH, T. et al. Interfacial micromorphology and tensile bond strength of dentin bonding systems after $\mathrm{NaCl}$ treatment. J Adhesive Dent, v.2, n.2, p.135-42, July 1999.

88. PILO, R. et al. Effect of core stiffness on the in vitro fracture of crowned, endodonticaly treated teeth. J Prosth Dent, v.88, n.3, p.302-6, Sept. 2002.

89. PONTIUS, O.; HUTTER, J.W. Survival rate and fracture strength of incisors restored with different post and core systems and endodonticaly treated incisors without coronoradicular reinforcement. J Endodont, v.28, n.10, p.710-5, Oct. 2002.

90. QUALTROUGH, A.J.E.; MANNOCCI, F. Tooth-colored post systems: a review. Operat Dent, v.28, n.1, p.86-91, Jan. 2003.

91. RAYGOT, C.G.; CHAI, J.; JAMESON, L. Fracture resistance and primary failure mode of endodonticaly treated teeth restored with a carbon fiber-reinforced resin post system in vitro. Int J Prosth, v.14, n.2, p.141-5, Apr. 2001.

92. REAGAN, S.E. et al. Effects of cyclic loading on selected post-and-core systems. Quint Int, v.30, n.1, p.61-7, Jan. 1999.

93. SIRIMAI, S.; RIIS, D.N.; MORGANO, S.M. An in vitro study of the fracture resistance and the incidence of vertical root fracture of pulpless teeth restored with six post-and-core systems. J Prosth Dent, v.81, n.3, p.262-9, Mar. 1999. 
94. STRUB, J.R.; PONTIUS, O.; KOUTAYAS, S. Survival rate and fracture strength of incisors restored with different post and core systems after exposure in the artificial mouth. J Oral Reha, v.28, n.2, p.120-4, Feb. 2001.

95. SCHWEIGER, M. et al. Microstucture and properties of a pressed glass-ceramic core to a zirconia post. Quint Dent Tech, v. 21, p.73-9, 1998.

96. SJÖGREN, G. et al. Clinical examination of leucite-reinforced glass-ceramic crowns (Empress) in general practice: a retrospective study. Int J Prosth, v.12, n.2, p.122-8, Mar. 1999.

97. SMITH, C.T.; SCHUMAN, N.J.; WASSON, W. Biomechanical criteria for evaluating prefabricated post-and-core systems: a guide for the restorative dentist. Quint Int, v.29, n.5, p.305-12, Mar. 2000.

98. SORENSEN, J.A.; ENGELMAN, M.J. Effect of post adaptation on fracture resistance of endodontically treated teeth. J Prosth Dent, v.64, n.4, p.41924, Oct. 1990.

99. SORENSEN, J.A.; ENGELMAN, M.J. Ferrule design and fracture resistance of endodontically treated teeth. J Prosth Dent, v.63, n.5, p.529-36, May 1990.

100. SORENSEN, J.A.; MARTINOFF, J.T. Cllinically significant factors in dowel design. J Prosth Dent, v.52, n.1, p.28-35, July 1984.

101. SORENSEN, J.A.; MITO, W.T. Rationale and clinical technique for esthetic restoration of endodontically treated teeth with the cosmopost and IPS empress post system. Quit Dent Tech, v.21, p.81-90, 1998.

102. TORBJÖRNER, A.; KARLSSON, S.; ÖDMAN, P.A. Survival rate and failure characteristics for two post designs. J Prosth Dent, v.73, n.5, p.439-44, May 1995.

103. VICHI, A. et al. An SEM evaluation of several adhesive systems used for bonding fiber posts under clinical conditions. Dent Materials, v.18, n.9, p.495-502, Sept. 2002.

104. VICHI, A.; GRANDINI, S.; FERRARI, M. Comparison between two clinical procedures for bonding fiber posts into a root canal: a microscopic investigation. J Endodont, v.28, n.5, p.355-60, May 2002.

105. XIBLE, A.A. Avaliação da resistência ao cisalhamento de três sistemas de núcleos intra-radiculares. Bauru, 2000. 92p. Dissertação (Mestrado) Faculdade de odontologia de Bauru, Universidade de São Paulo.

106. YAMAN, P.; THORSTEINSSON, T.S. Effect of core materials on stress distribution of posts. J Prosth Dent, v.68, n.3, p.416-20, Sept. 1992. 
107. WISKOTT, H.W.A.; NICHOLLS, J.I.; BELSER, U.C. Stress fatigue: basic principles and prosthodontic implications. Int J Prosth, v.8, n.2, p.105-16, Mar/Apr. 1995. 
ABSTRACT 


\section{ABSTRACT}

This study compared the effect of cyclic load, survival rate, residual strength, the mode of fracture and relationship between $\mathrm{MD}$ and $\mathrm{BL}$ dimensions and strength of endodontically treated teeth restored with three esthetic post systems subjected to thermal and mechanical cyclic load. Sixty canines were selected for the study. They were endodontically treated with guta percha points and calcium hydroxide cement (Sealapex - Kerr), decoronated $1.5 \mathrm{~mm}$ above the cementum enamel junction and prepared for metal free ceramic crowns $(1.0 \mathrm{~mm}$ in $\mathrm{BL}$ and $0.8 \mathrm{~mm}$ in $\mathrm{MD}$ direction and rounded shoulder), leaving a remaining dentin amount of $1.5 \mathrm{~mm}$ high as ferrule effect. After BL, MD dimensions were obtained, they were distributed in 6 groups according to the stratified method. Groups 1 and 2 were restored with $1.7 \mathrm{~mm}$ in diameter zirconia posts (Cosmopost - Ivoclar Vivadent) and heat pressed glass-ceramic cores (IPS Empress Cosmo - Ivoclar Vivadent); groups 3 and 4 were restored with $1.5 \mathrm{~mm}$ in diameter fiber reinforced composite posts (FibreKor - Jeneric Pentron) and group 5 and 6 were restored with $1.65 \mathrm{~mm}$ in diameter titanium posts (AZthec Anchor Dentatus). Direct resin composite (Build It FR - Jeneric Pentron) were used as cores for the 4 latest groups. All specimens were restored with all ceramic crowns (Empress 2 - Ivoclar). In all groups, a resin cement/adhesive system (Cement It/Bond It Primer $A+B)$ was used to lute the posts to root canals and metal free porcelain crowns to the teeth. Twenty-four hours after cementing the crowns, the specimens were subjected to $300 \mathrm{x}$ thermal cycles with temperature ranging from $5^{\circ} \mathrm{C}$ to $55^{\circ} \mathrm{C}$ with $30 \mathrm{sec}$ of dwell time. Specimens were then embedded in resin acrylic, mounted in aluminum blocks. Groups 2, 4 and 6 were subjected $500.000 x$ to a mechanical load of $250 \mathrm{~N}$ in a frequency of $1.7 \mathrm{~Hz}$. All specimens were set in an Instron machine and subjected to static load until failure. Data were recorded and analyzed using Two-way ANOVA, Tukey, Pearson Correlation, Chi Square and Exact Fischer tests. Group 1 $(1165.7 \pm 210.95 \mathrm{~N})$ was higher than group $2 \quad(886.50 \pm 170.62 \mathrm{~N})$; group 3 $(1041.50 \pm 231.20 \mathrm{~N})$ was higher than group $4(762.20 \pm 113.63 \mathrm{~N})$ and group 5 $(985.40 \pm 99.89 \mathrm{~N})$ was higher than group $6(768,90 \pm 72.95 \mathrm{~N})$. Zirconia group values were higher than all the other groups $(p<0.05)$; there was no statistically difference between fiber reinforced composite and titanium group even after the cyclic loading $(p=0.146)$; cyclic loading reduced significantly the fracture strength of all groups $(p<0.00)$; there was no correlation between type of posts and decrease in fracture strength $(p=0.778)$; there were a weak but significant correlation between MD specimens dimension and load to failure $(r=0.260$ e $p=0.044)$; there was no correlation 
between the mode of failure and type of posts $\left(\chi^{2}=4.484\right.$ e $\left.p=0.885\right)$. It was concluded that: 1-Teeth restored with zirconia posts and glass-ceramic cores showed the highest strength to fracture, regardless the cyclic loading application; 2- The cyclic loading treatment lowered the fracture strength of all groups tested; 3- Fiber reinforced composite posts group values were not significantly different from titanium posts regardless the cyclic loading application; 4- Larger MD dimension may favor an increase in the fracture strength of teeth restored with pre-fabricated post systems. 
APÊNDICE 


\section{APÊNDICE}

Equipamentos e materiais com respectivas marcas, lote e origem, utilizados no presente trabalho.

\begin{tabular}{|c|c|c|c|}
\hline EQUIPAMENTO & MARCA & LOTE & ORIGEM \\
\hline Microscópio ótico & $\begin{array}{l}\text { Swift Instruments } \\
\text { International S/A }\end{array}$ & & Japão \\
\hline Cortador de dentes & Isomet 2000 Buehler & & EUA \\
\hline $\begin{array}{l}\text { Brocas diamantadas para } \\
\text { preparo de coroas de } \\
\text { porcelana pura }\end{array}$ & Premier Two Striper & $\begin{array}{l}219 \\
\text { ISO\#146014 }\end{array}$ & EUA \\
\hline Paquímetro digital & Mitutoyo & & Japão \\
\hline $\begin{array}{l}\text { Broca diamantada esférica } \\
n=1111\end{array}$ & KG Sorensen & & Brasil \\
\hline $\begin{array}{l}\text { Limas K-file Asst \#15-40, } \\
\text { 25mm }\end{array}$ & Patterson & 0212000138 & Alemanha \\
\hline Cones de papel absorvente & Patterson & P33798 & Brasil \\
\hline Cones de guta percha & Patterson & 05697 & China \\
\hline $\begin{array}{l}\text { Cimento de hidróxido de } \\
\text { cálcio }\end{array}$ & Sealapex, Kerr & 02496 & EUA \\
\hline $\begin{array}{l}\text { Condensadores } \\
\text { endodônticos }\end{array}$ & Kerr & & Brasil \\
\hline $\begin{array}{l}\text { Instrumento para corte de } \\
\text { guta percha }\end{array}$ & Touch'n Heat, Kerr & & EUA \\
\hline $\begin{array}{l}\text { Pinos pré-fabricados de } \\
\text { cerâmica de zircônia }\end{array}$ & Cosmopost, Ivoclar Vivadent & $\begin{array}{l}\text { E49561; } \\
\text { E11486; } \\
\text { B23841; }\end{array}$ & Suíça \\
\hline Broca de Peeso no 1 & Maillefer & & Suiça \\
\hline Silicona de adição & Express - 3M & & EUA \\
\hline Gesso especial & $\begin{array}{l}\text { Die Stone Velmix Classic, } \\
\text { Kerr }\end{array}$ & $4-1229$ & EUA \\
\hline $\begin{array}{l}\text { Misturador mecânico a } \\
\text { vácuo }\end{array}$ & $\begin{array}{l}\text { Vac-U-Vestor, Whip Mix } \\
\text { Mode E }\end{array}$ & & EUA \\
\hline $\begin{array}{l}\text { Líquido endurecedor de } \\
\text { gesso }\end{array}$ & $\begin{array}{l}\text { Stone Die \& Hardener } \\
\text { Resin, George Taub } \\
\text { Products }\end{array}$ & & EUA \\
\hline Isolante para gesso & $\begin{array}{l}\text { Isolating Liquid IPS } \\
\text { Empress, Ivoclar Vivadent }\end{array}$ & B49272 & Liechtensteir \\
\hline
\end{tabular}




\begin{tabular}{|c|c|c|c|}
\hline EQUIPAMENTO & MARCA & LOTE & ORIGEM \\
\hline Cera para escultura & Pro Art, Ivoclar Vivadent & & Alemanha \\
\hline $\begin{array}{l}\text { Revestimento para } \\
\text { fundição de Empress } 2\end{array}$ & $\begin{array}{l}\text { IPS Empress, Ivoclar } \\
\text { Vivadent }\end{array}$ & $\begin{array}{l}\text { \#E97042/Liq } \\
\text { \#097111 }\end{array}$ & Liechtenstein \\
\hline Forno de fundição & Vulcan 3-550, Ney & & EUA \\
\hline Lingotes de porcelana & $\begin{array}{l}\text { IPS Empress Cosmo } \\
\text { Post, Ivoclar-Vivadent }\end{array}$ & D64021 & Liechtenstein \\
\hline $\begin{array}{l}\text { Forno de fundição de } \\
\text { porcelana }\end{array}$ & EP 500, Ivoclar Vivadent & & Liechtenstein \\
\hline Bico jateador & $\begin{array}{l}\text { Renfert Basic } \\
\text { Professional, Renfert }\end{array}$ & & Alemanha \\
\hline Disco diamantado & NTI-Kahla & & Alemanha \\
\hline Líquido evidenciador & Accufilm IV, Parkell & & EUA \\
\hline Ácido fluorídrico a 5\% & $\begin{array}{l}\text { IPS Ceramic, Ivoclar } \\
\text { Vivadent }\end{array}$ & E57837 & Lietchenstein \\
\hline Silano & $\begin{array}{l}\text { Monobond S, Ivoclar } \\
\text { Vivadent }\end{array}$ & & Liechtenstein \\
\hline $\begin{array}{l}\text { Agente de adesão } \\
\text { dentinária }\end{array}$ & $\begin{array}{l}\text { Bond It Primer A e B, } \\
\text { Jeneric Pentron }\end{array}$ & 76742 & EUA \\
\hline $\begin{array}{l}\text { Pinos pré-fabricados de } \\
\text { resina composta } \\
\text { reforçados por fibra de } \\
\text { vidro }\end{array}$ & Fibrekor, Jeneric Pentron & 74074 & EUA \\
\hline Ácido fosfórico a $37 \%$ & Bisco & & EUA \\
\hline $\begin{array}{l}\text { Pinos pré-fabricados de } \\
\text { titânio }\end{array}$ & $\begin{array}{l}\text { AZtech Titanium Anchor, } \\
\text { Dentatus }\end{array}$ & 43756 & Suíça \\
\hline $\begin{array}{l}\text { Cimento resinoso de } \\
\text { polimerização dupla }\end{array}$ & $\begin{array}{l}\text { Cement It Universal C \& } \\
\text { B opaque, Jeneric } \\
\text { Pentron }\end{array}$ & 78063 & EUA \\
\hline Broca de Lentulo & Maillefer & & Suiça \\
\hline $\begin{array}{l}\text { Resina reforçada com } \\
\text { fibras de vidro de } \\
\text { polimerização dupla }\end{array}$ & $\begin{array}{l}\text { Build It Fiber Reinforced } \\
\text { Core, Jeneric Pentron }\end{array}$ & 77941 & EUA \\
\hline $\begin{array}{l}\text { Formas plásticas para } \\
\text { confecção de núcleos } \\
\text { de preenchimento }\end{array}$ & $\begin{array}{l}\text { Build It! Core Forms, } \\
\text { Jeneric Pentron }\end{array}$ & 73307 & EUA \\
\hline
\end{tabular}




\begin{tabular}{|c|c|c|c|}
\hline EQUIPAMENTO & MARCA & LOTE & ORIGEM \\
\hline Sonda exploradora $\mathrm{n}^{\circ} 5$ & Hu Friedy & & EUA \\
\hline Brocas carbide & Brasseler & 358951 & EUA \\
\hline Lingotes de porcelana & $\begin{array}{l}\text { Empress 2, Ivoclar } \\
\text { Vivadent }\end{array}$ & $\begin{array}{l}\text { A15064 cor } \\
400 ; A 24547 \\
\text { cor } 300\end{array}$ & Liechtenstein \\
\hline Borrachas diamantadas & Cerapol, Edenta & & Suíça \\
\hline Massa para glaze & $\begin{array}{l}\text { IPS Empress Universal } \\
\text { Glazing Paste, Ivoclar } \\
\text { Vivadent }\end{array}$ & E70295 & Liechtenstein \\
\hline Forno para cerâmica & Vita Vacumat 40, Vita & & Alemanha \\
\hline Cera utilidade & Kerr & & EUA \\
\hline Resina acrílica & Formatray, Kerr & E57837 & EUA \\
\hline Espátula 7 & Duflex & & Brasil \\
\hline $\begin{array}{l}\text { Máquina de ensaios } \\
\text { universal }\end{array}$ & $\begin{array}{l}\text { Instrom, Modelo } 4202 \text { - } \\
\text { Canton }\end{array}$ & & EUA \\
\hline Microscópio ótico & $\begin{array}{l}\text { Stereozoom } 7 \mathrm{w} / \text { Trans- } \\
\text { Illumination Base }\end{array}$ & & EUA \\
\hline
\end{tabular}

